\title{
The crab spider genus Uraarachne Keyserling (Araneae: Thomisidae) in Argentina, Uruguay and Paraguay: a proposal of its senior synonymy over Plancinus Simon, and description of four new species
}

\author{
Cristian José GRISMADO ${ }^{1} \&$ Helga Cecilia ACHITTE-SCHMUTZLER ${ }^{2}$
}

\begin{abstract}
${ }^{1}$ División Aracnología, Museo Argentino de Ciencias Naturales "Bernardino Rivadavia"- CONICET, Av. Ángel Gallardo 470, C1405DJR, Buenos Aires, Argentina. Corresponding author: grismado@macn.gov.ar. ${ }^{2}$ Cátedra de Biología de los Artrópodos, Facultad de Ciencias Exactas y Naturales, Universidad Nacional del Nordeste, Avda. Libertad 5470 (3400) Corrientes, Argentina.
\end{abstract}

\begin{abstract}
The crab spider genus Uraarachne Keyserling 1880 currently comprises two species: U. longa Keyserling (type species, from Brazil, and herein newly recorded from Paraguay) and U. vittata (Caporiacco) from French Guiana. Uraarachne is herein proposed, on base of somatic and genitalic characters, as a senior synonym of Plancinus Simon 1886, which is known from three species from Uruguay: P. runcinioides Simon (type species), $P$. cornutus Simon, and P. brevipes Simon (all three transferred here to Uraarachne). Uraarachne runcinioides new comb., (type species of Plancinus), and U. cornuta new comb., are reported for the first time for Argentina and redescribed, based on the type specimens and new material, including the first known males. Four new species are described from Argentina: U. panthera n. sp., and U. ceratophrys n. sp. (from Misiones province, both on base of single male specimens), U. toro n. sp. (from Salta province, female only), and U. kapiity n. sp. (from the argentine provinces of Chaco, Corrientes, and Entre Ríos, and from Paraguay, on base of both sexes). Two additional species are transferred to Uraarachne: Runcinia plana Simon, previously known only from juveniles from Paraguay (adults described here for the first time, and distribution extended to central-eastern Argentina), and Misumenoides variegatus Mello-Leitão, known from the holotype male from Santa Fe (female described here for the first time, and distribution extended to Paraguay and Buenos Aires, Argentina). Platyarachne argentina Mello-Leitão and Erissoides argentinus Mello-Leitão are newly synonymized with Uraarachne runcinioides. The relationships of the genus are breafly discussed, proposing a close relationship with Runcinia Simon.
\end{abstract}

Key words: Neotropics, Araneae, Uraarachne, crab spiders, taxonomy, new species.

Resumen: El género de arañas cangrejo Uraarachne Keyserling 1880, actualmente comprende dos especies: $U$. longa Keyserling (especie tipo, de Brasil y recientemente registrada en Paraguay) y U. vittata (Caporiacco) de Guayana Francesa. Aquí se propone Uraarachne -sobre la base de varios caracteres de morfología somática y genital- como sinónimo anterior de Plancinus Simon 1886, conocido hasta la fecha por tres especies de Uruguay: P. runcinioides Simon (especie tipo), P. cornutus Simon y P. brevipes Simon (las tres se transfieren aquí a Uraarachne). Uraarachne runcinioides n. comb. (especie tipo de Plancinus) y U. cornuta n. comb. se citan por primera vez para Argentina y son redescriptas en base a los especímenes tipo y a material recientemente encontrado en colecciones argentinas, incluyendo los primeros machos conocidos. Cuatro nuevas especies se describen para Argentina: U. panthera n. sp. y U. ceratophrys n. sp. (de la provincia de Misiones, ambas en base a especímenes machos), U. toro n. sp. (de la provincia de Salta, sólo una hembra), y U. kapiity n. sp. (de las provincias argentinas de Chaco, Corrientes y Entre Ríos, y de Paraguay, en base a los dos sexos). Adicionalmente, otras dos especies se transfieren a Uraarachne: Runcinia plana Simon, conocida previamente por juveniles de Paraguay (los adultos se describen por primera vez, y se extiende su distribución conocida hasta el centro-este de Argentina), y Misumenoides variegatus Mello-Leitão, conocida previamente por el macho holotipo de Santa Fe (la hembra se describe aquí por primera vez, extendiéndose su distribución conocida hasta Paraguay y Buenos Aires). Platyarachne argentina Mello-Leitão y Erissoides argentinus Mello-Leitão son sinonimizadas con Uraarachne runcinioides. Los parentescos probables del género son brevemente discutidos, proponiéndose una posible cercanía con Runcinia Simon.

Palabras clave: Neotrópico, Araneae, Uraarachne, arañas cangrejo, taxonomía, nuevas especies. 


\section{INTRODUCTION}

The crab spider genus Uraarachne was originally described by Keyserling (1880) to accommodate the Brazilian species Uraarachne longa, diagnosed by the abdomen very elongated and ending in a conical projection beyond the spinnerets. Traditionally it was recognized by this unique feature for the genus (for example, Simon, 1895; Mello-Leitão, 1929; Lehtinen, 2004). Simon (1895b:1025) listed Uraarachne as "genus invisum", and pointed out that it was as very similar to Runcinia except by the abdominal shape and the unarmed posterior legs. The genus remained monotypic until Rinaldi (1988) transferred to it Odontoruncinia vittata Caporiacco 1954, mentioning that both species share, besides the elongated abdomen, a row of denticles on the cheliceral promargin "as in Apyre" (see Caporiacco 1954: 143). However, these "denticles" are actually enlarged setae, very similar to those found in other thomisid genera (for example, Pistius, Runcinioides, Runcinia, the species formerly belonging to Plancinus), which were called "promargin cheliceral whisker setae" by Ramírez (2014: 52).

Ono (1988: 220) listed Uraarachne in its own monotypic tribe (Uraarachnini) belonging to the subfamily Thomisinae, and later Lehtinen (2004) listed it in his Misumenini.

Another enigmatic genus that has never been revised after its description, and with limits and relationships also poorly known is Plancinus Simon 1886, genus largely neglected in the history of taxonomy and systematics on Neotropical crab spiders. Simon described the currently three known species in the same paper: $P$. runcinioides, $P$. cornutus, and P. brevipes, all collected by Karl Berg in unspecified localities in Uruguay. Simon selected later $P$. runcinioides as the type species (1892: 1023), an intriguing decision since the species was described from an immature. However, this juvenile is currently stored in the same vial together with two adult females in the collection of the Muséum National d'Histoire Naturelle of Paris (see below). Plancinus was originally diagnosed by Simon (1886: 174) by the carapace slightly longer than wide, the anterior eyes located on a transverse and sinuous carina, with lateral angular projections prominent (although in a less extent than in Thomisus Walckenaer) and by having a truncate abdomen, widened in the posterior part. Simon (1886) mentioned that some morphological characters resemble those of the Old World genera Pistius Simon and Runcinia Simon ("Gen. Pistio et Runciniæ affinis"). However, he later mentioned that Plancinus is similar to Thomisus (e.g., Simon 1892: 1019, 1022), especially by the above mentioned morphology of the ocular area and the abdomen, suggesting that Plancinus replaces Thomisus in South America.

After the original description, Simon (1909) described a fourth species, $P$. advecticius from Vietnam, currently Runcinia insecta (L. Koch, 1875). The genus was later only mentioned in some comparative discussions about relationships among the potentially close genera, mainly by characters as the eye disposition and the anterior carina. Dippenaar-Schoeman (1983: 37) suggested its similarity with Runcinia and Bonapruncinia Benoit; on the other hand, Ono (1988: 195) proposed that it could be related to Runcinia, Thomisus and Massuria Thorell. Finally, Lehtinen (2004) proposed that Plancinus is not monophyletic, because he considered that the type species (P. runcinioides) is very different from the other two (P. cornutus and P. brevipes), even suggesting that the former is a member of the tribe Platyarachnini (Thomisinae), close to Uraarachne, and the two latter belong to a different subfamily, Stephanopinae (Lehtinen 2004: 178 , and see tables 1 and 2 ).

After the study of the type series of Uraarachne longa (two immature syntypes from Porto Alegre, deposited in the Museum für Naturkunde, Berlin, Fig. 2A), we found that they share the main morphological features of Plancinus (especially the ocular area, and carapace morphology), differing only by the elongated abdomen. The adult specimens redescribed by Rinaldi (1988), show, again, suggestive similarities in genitalic features with Plancinus females (anterior epigynal hood followed by a slightly sclerotized median septum, globose spermathecae, and short, inconspicuous copulatory ducts). These characters allowed us to think that the abdominal shape could be very variable in closely related species (or just an autapomorphy of $U$. longa), as is already known in the very similar genus Runcinia in the Old World (see below). After studying newly collected adult specimens of $U$. longa from Paraguay, we concluded that this species is congeneric with all the species currently listed in Plancinus, and that the generic name Uraarachne has priority for the group. In this contribution, we describe four new species of Urarachne, we also redescribe the species herein transferred to Uraarachne of Argentina, Uruguay and Paraguay, including those of Plancinus, one transferred from 
Runcinia and one from Misumenoides (Runcinia plana Simon, and Misumenoides variegatus Mello-Leitão).

\section{MATERIAL AND METHODS}

Specimens for this study come from the following institutions (acronyms and curators in parentheses): Cátedra de Biología de los Artrópodos de la Universidad Nacional del Nordeste, Corrientes, Argentina (CARTROUNNE; Gilberto Avalos), Museo Argentino de Ciencias Naturales "Bernardino Rivadavia", Buenos Aires, Argentina (MACN-Ar; Martín J. Ramírez), Museo de La Plata, La Plata, Argentina (MLP; Cristina Damborenea and Luis Pereira), Museo Municipal de Ciencias Naturales "Lorenzo Scaglia", Mar del Plata, Argentina (MMPE, Juan Farina), Museo Nacional de Historia Natural del Paraguay, San Lorenzo, Paraguay (MNHNP; John Kochalka), Museum für Naturkunde, Berlin, Germany (ZMB, Jason Dunlop), Museum National d'Histoire Naturelle, Paris, France (MNHN; Christine Rollard), The Natural History Museum, London, United Kingdom (BMNH, Janet Beccaloni), and Naturmuseum Senckenberg, Frankfurt, Germany (SMF, Peter Jäger). The format of description, including notation of leg macrosetae, follows mostly Ono (1988), the terminology for female copulatory structures follow mostly Szymkowiak (2014). All measurements are in millimeters. Female internal genitalia were examined cleared in clove oil, in some cases after digestion using a pancreatin solution (Álvarez-Padilla \& Hormiga, 2008). They were placed in temporary slides and photographed under an Olympus BH-2 transmitted light microscope; drawings were made with a camera lucida. Measurements and photographs of habitus and male palps were made in a Leica M165C stereoscopic microscope using Leica Application Suite 3.8. All stacked-focus images were processed in Helicon Focus 6.8 (https:// www.heliconsoft.com). Scale bars where generated by the program Leica Application Suite 3.8; unfortunately, some images taken in European Museums lack the scale bars, which could not be recovered. Scanning electron micrograph images were taken in a Philips FEI XL 30 TMP scanning electron microscope at Museo Argentino de Ciencias Naturales, Buenos Aires. We report GPS coordinates of the localities when available; otherwise, we provide coordinates (denoted between parentheses) obtained from Google Earth (http://earth.google.com) from label locality data.
The maps were made with ArcGIS 10.5 sofware (ESRI, 2016) ESRI (Environmental Systems Research Institute). 2016. ArcGIS desktop 10.5. ESRI, Redland, California.

Abbreviations: AH, anterior hood; ALE, anterior lateral eyes; $\mathrm{AME}$, anterior median eyes; $\mathrm{CD}$, copulatory duct; $\mathrm{CO}$ copulatory opening; $\mathrm{E}$, embolus; ELP, epigynal lateral plate; ER, epigynal rim; ES, epigynal suture; FD, fertilization ducts; MS, median septum; PLE, posterior lateral eyes; PME, posterior median eyes; RTA, retrolateral tibial apophysis; S, spermatheca; SA, spermathecal apodema, SGT, spiral groove of tegulum, T, tegulum; TP, tegular pocket; VTA, ventral tibial apophysis.

The following specimens were examined for comparative study:

Misumenoides magnus (Keyserling, 1880): $\sigma^{*}+$ syntypes of Runcinia magna from "N. Granada" (Colombia), no locality detailed (BMNH 1890.7.1.3859, examined through photographs, Fig. 3).

Pistius truncatus, (Pallas, 1772): $0^{7}$ from Germany: Dessau: Torten'sche Schweitz leg. 2.V.1934, H. Wiehle leg. (SMF 21664/1); o" from Germany: Berlin: Pfaueninsel, no date, J. Wunderlich leg. and det. (SMF 60896); $q$ from Germany: Rheinland-Pfalz: near Mainz, 5.V.1957, Gonsenheimer Wald leg. (SMF 64727); o from Germany: Rheinland-Pfalz: $49^{\circ} 41.243^{\prime}$ N, $\quad 8^{\circ} 20.325^{\prime} \mathrm{E}, \quad$ E. Donnersbergkrs., bei Kirchheimbolanden Raststätte Heubergerhof, A 63, 300 m M. Schwalbach leg., 31.VIII.2008, P. Jäger det. (SMF 58574).

Runcinia aethiops Simon: 2 immature 9 from Democratic Republic of the Congo: Faradje, R. de Lessert det. (MLP 18433)

Runcinia grammica (C. L. Koch 1837): $30^{\text {" }}$ 5 o from Spain, no locality detailed, H. Wiehle leg. 1930 (SMF 21877, Figs. 6, 7 a-g, 8), 1 아 from Italy, Sardinia, J. Wunderlich leg., no date (SMF 60900, Fig. 7 h, i)

Runcinioides argenteus Mello-Leitão, 1929; 2 ơ, 3, 6 juvs. from Argentina: Santa Fe (no date, no collector, MACN-Ar 19118).

\section{RESULTS}

\section{Taxonomy}

\section{Uraarachne Keyserling, 1880}

Uraarachne Keyserling, 1880: 130. Type species by monotypy Uraarachne longa Keyserling 1880. Simon 1895b: 1025; Petrunkevitch 1911: 

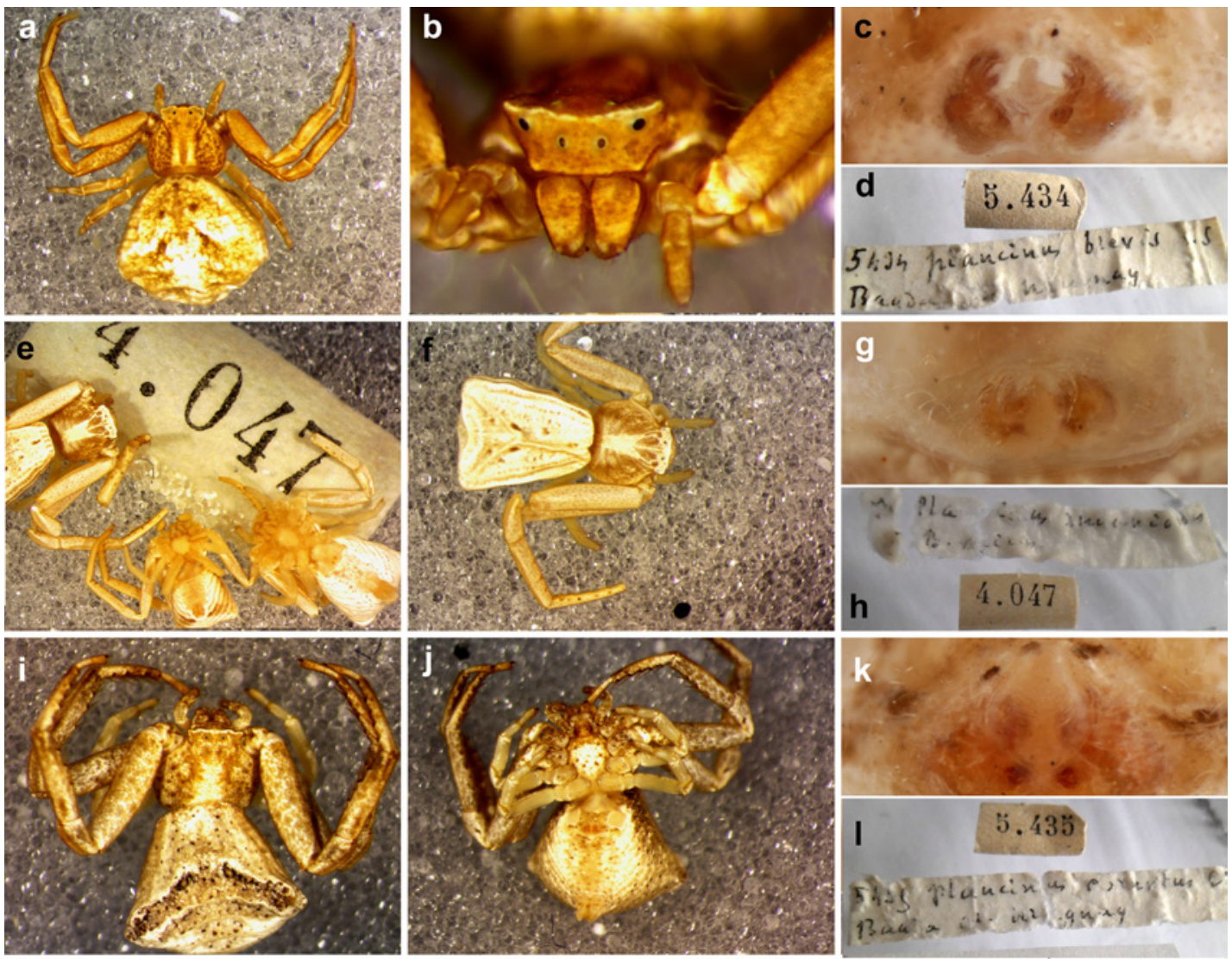

Fig. 1. Type specimens of Plancinus Simon (MNHN): a-d, P. brevipes Simon, female holotype; e-h, $P$. runcinioides Simon, i-l, P. cornutus Simon. a, habitus dorsal, b, carapace, anterior, e, juvenile holotype together with two non type adult females (see text), f, habitus dorsal of one female, i, female syntype, habitus dorsal, j, same, ventral; c, g, k, female epigynum; d, h, l, original MNHN labels. Images without scales.

436; 1928: 170; Mello-Leitão 1929: 270; Roewer 1955: 863; Bonnet 1956: 4775; Ono 1988: 220; Lehtinen 2004: 176.

Odontoruncinia Caporiacco, 1954: 142. Type species by original designation Odontoruncinia vittata Caporiacco 1954. Brignoli 1983: 612. Synonymized by Rinaldi (1988).

Plancinus Simon, 1886: 174. Type species by original posterior designation Plancinus runcinioides Simon 1886 (Simon 1892: 1023). Petrunkevitch 1928: 169; Roewer 1955: 852; Bonnet 1956: 3698; Ono 1988: 195; Lehtinen 2004: 178. New synonymy.

Diagnosis. Uraarachne resembles typical Runcinia by the combined presence of a whitish transverse carina on the ocular area, lateral folds on the abdomen, conspicuous pointed setae along the lateral margin of carapace, and internal rows of ridges on the RTA of male palps. Uraarachne differs by the slightly elongated and less widened carapace, with more protruding cephalic area; the RTA of males are longer and slightly curved, and they have an indentation (tegular pocket) at the level of the internal end of the spiral groove of tegulum, making visible most of the embolus base (Figs. 4a, 5a). Female genitalia are also similar to those of Runcinia, by having an anterior hood and globose spermathecae, but differ by the shorter copulatory ducts (Figs. 5h, 9i, 10i, 12i, 14i, 16i, 18i, 19i).

Description. Female. Small to medium-sized crab spiders (4.5-10). Carapace slightly longer than wide; flattened above; anterior margin straight, cephalic area clearly protruding from the thoracic one; ocular region raised, with lateral corners protruding outwards, although lesser acute than in Thomisus (especially shallow in $U$. plana and $U$. variegata). Both eye rows slightly recurved, with nearly equidistant eyes. All dorsal 

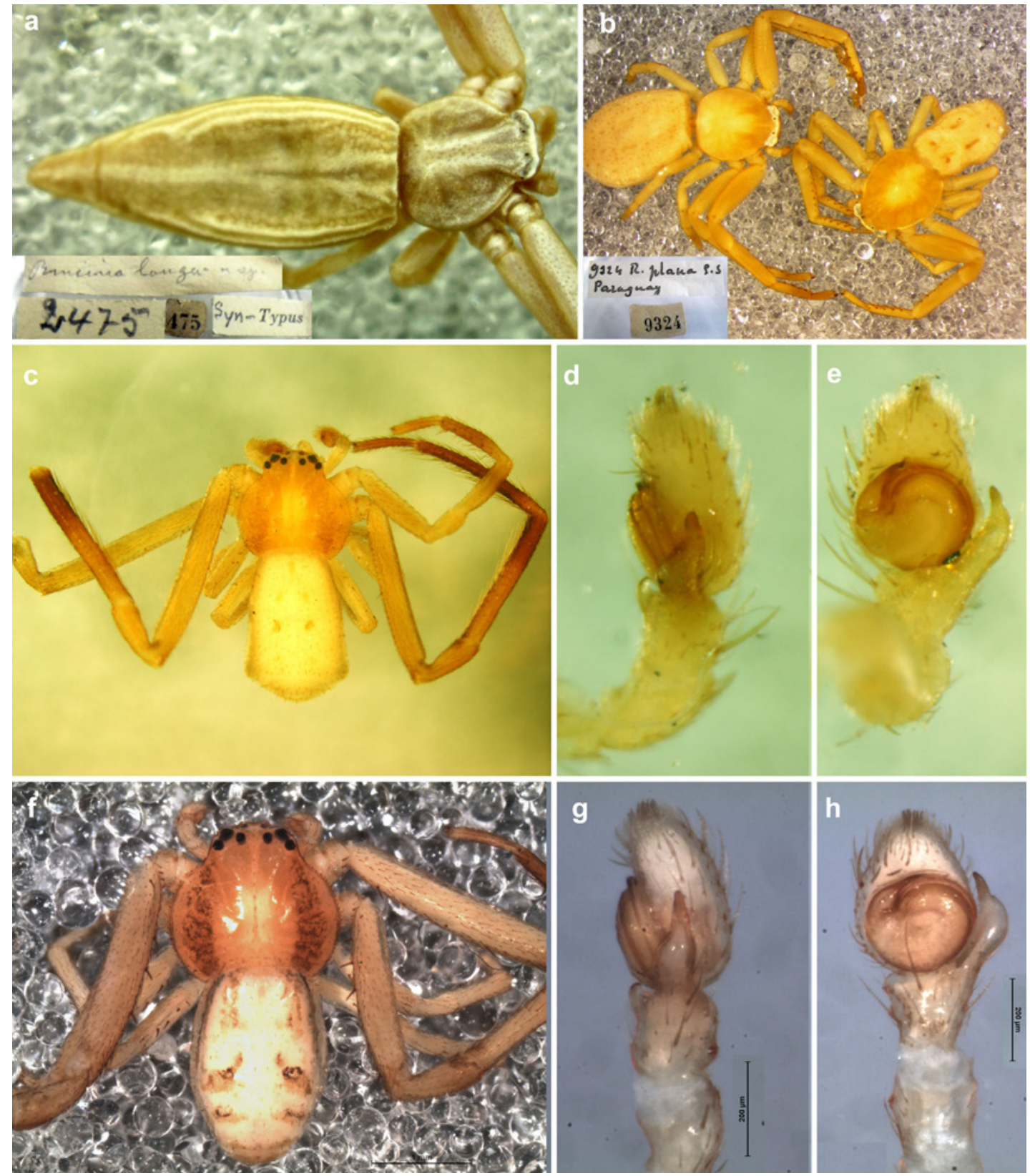

Fig. 2. Type specimens of thomisids: a, juvenile syntype of Uraarachne longa Keyserling (ZMB), b, juvenile syntypes of Runcinia plana Simon (MNHN), c-e, syntype male of Platyarachne argentina Mello-Leitão (MLP), $\mathrm{f}$-h, holotype male of Misumenoides variegatus Mello-Leitão (MLP). a, b, habitus dorsal with original labels; c, f, habitus dorsal; d, g, left palp retrolateral; e, h, same, ventral. a-f, images without scales, g, h=200 $\mu \mathrm{m}$.

cuticle covered with usually aligned short, blunt setae; margins of the thoracic area conspicuously rebordered with pointed setae. Sternum heartshaped, longer than wide, labium nearly pentagonal, endites convergent, without modifications. Abdomen variable: widened posteriorly (caudally rounded or truncated), or elongated (with a projection surpassing the level of the spinnerets in U. longa, Fig. 9); with lateral folds similar to those of Runcinia. Dorsum covered with nearly aligned blunt setae. Legs covered with short setae; formula I-II-IV-III, forelegs with well de- 
veloped ventral macrosetae on tibiae and metatarsi, tarsi and metatarsi IV bearing ventral setae more abundant and relatively thickened. Genitalia: epigynum not very sclerotized, anterior hood relatively wide, flanked by two lateral epigynal sutures; posterior to the hood there are a median septum (with soft cuticle, with transverse folds) reaching to the lateral plates (the median septum is more expanded laterally in $U$. cornuta, and $U$. variegata); copulatory openings inconspicuous, situated near the anterolateral margins of the median septum, under (or near to) the lateral epigynal sutures. Caudally to the median septum, there are two small markings (or blind cavities) corresponding to the spermathecal apodemes (sensu Loerbroks 1983). Internal genitalia consisting in large, relatively globose primary spermathecae, copulatory ducts relatively short, apparently with only one torsion, running between the spermathecae, and connecting to them anteromedially (Figs. 5h, 9i, 10i, 12i, 14i, 16i, 18i, 19i).

Male. As in female except by the following. Smaller than females (2.8-4.2), with longer and thinner legs, forelegs with dark annulations on tarsi, metatarsi and, sometimes, on tibiae; ventrally with also longer and thinner macrosetae (sometimes with unequal size, and accompanied by long and stout hairs that difficult the recognizion of the true serial ventral macrosetae); body setae usually more prominent; abdomen smaller. Genitalia: palp with relatively elongated and slightly sinuous RTA, with a ventral expansion presumably corresponding to their fusion with the ITA, and with apex with internal row of ridges; VTA small. Bulb discoidal, with medium sized embolus; tegulum with a ventral indentation (tegular pocket) on the prolateral side, nearly at the level of the internal end of the spiral groove of tegulum.

Distribution. Known from French Guiana, Brazil, Uruguay, Paraguay and the northern half of Argentina (maps 1-4).

Composition. U. longa Keyserling, U. vittata (Caporiacco), U. runcinioides (Simon) n. comb., $U$. cornuta (Simon) n. comb., U. brevipes (Simon) n. comb., U. plana (Simon) n. comb., U. variegata (Mello-Leitão) n. comb.,U. ceratophrys n. sp., $U$. panthera $\mathrm{n}$. sp., U. toro n. sp., and U. kapiity $\mathrm{n}$. sp.

Remarks. We have found two different ecological "morphs": the first five species described below (together with the type species of the genus) are relatively elongated species (except the female of $U$. variegata), with usually lighter co- lorations, that live in grasses and other plants, mostly around aquatic environments. On the other hand, the last four are dark-patterned species, with shortened bodies, and inhabitants of the foliage, mainly in forested habitats.

\section{Uraarachne longa Keyserling, 1880}

(Figs. 2a, 9, Map 1)

Uraarachne longa Keyserling, 1880: 130. Two immature females syntypes from Brazil: Porto Alegre, deposited in ZMB 2475, examined. Roewer 1955: 863; Bonnet 1956: 4776; Rinaldi, 1988: 27; Lehtinen 2004: 176.

Notes. Although Lehtinen (2004: 176), reported that the female holotype was "originally in the University of Berlin, present depository unknown", the vial \#2475 of the ZMB contains two immature specimens labeled as syntypes (Fig. $2 a$ ). The locality of the syntype specimens are currently illegible in the original label, but was taken from the original publication.

Diagnosis. $U$. longa differ from all other species of the genus by the elongated abdomen, remarkably projecting beyond the spinnerets.

Description. See Keyserling (1880) and Rinaldi (1988).

Other material examined. PARAGUAY:

Amambay: Parque Nacional Cerro Corá. 2.XI.1983, J.A. Kochalka coll., night collecting in temporary flooded grassland $2 \%, 10^{\prime}$ (MNHNP [IBNP-Invert.-JAK-CR-2556, Fig. 9]).

Distribution. Brazil (Rio Grande do Sul, São Paulo, and Rio Grande do Norte) and Paraguay (Amambay).

Uraarachne runcinioides (Simon, 1886), new combination

(Figs. 1e-h, 2c-e, 4, 10, 11, 23a-b, 25a-b, Map 1)

Plancinus runciniodes Simon, 1886: 174. Juvenile holotype from "Banda Oriental del Uruguay" (currently Uruguay), presumably collected by Karl Berg, deposited in MNHN 4047, examined. Simon, 1892: 1023 (designation as type species of the genus). Roewer 1955: 852; Bonnet 1956: 3699; Lehtinen 2004: 178.

Erissoides argentinus Mello-Leitão, 1931: 96. Female holotype from "Rosas, República Argentina" (currently Rosas, Estación del Ferrocarril General Roca, Las Flores, Buenos Aires Province, Argentina) (S35 58'0.00", W58 $\left.56^{\prime} 23.00^{\prime \prime}\right)$, originally deposited in MNRJ, lost. New synonymy. 

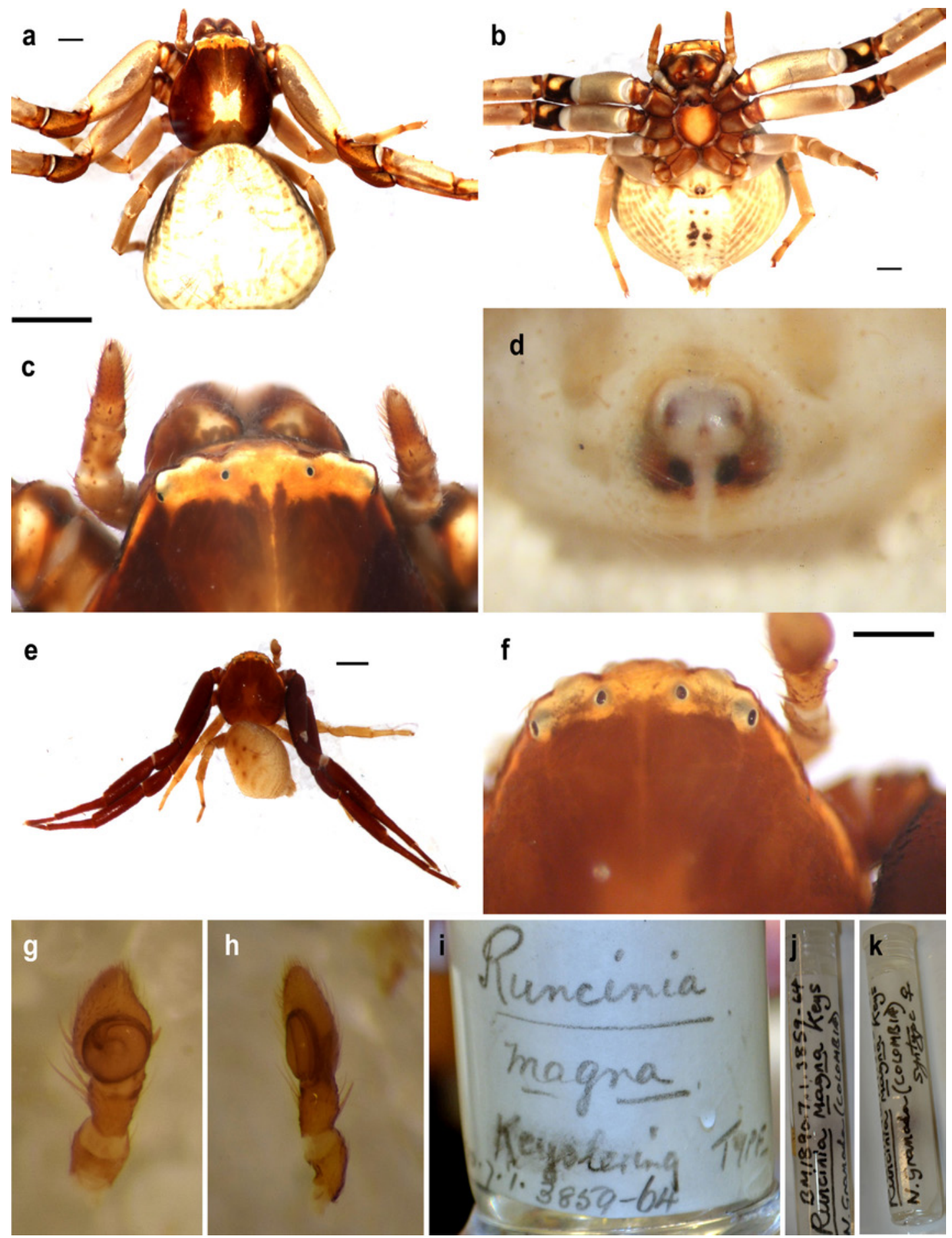

Fig. 3. Syntypes of Runcinia magna Keyserling, type species of Misumenoides Cambridge (BMNH, images courtesy of D. Sherwood), a-d, female, e-h, male, i-k, labels of the containing jar and vial. a, e, habitus dorsal view, b, same, ventral, c, f, ocular region, dorsal view, g, left palp, ventral view, h, same, retrolateral. d, g-k, images without scales, a, b, c, e, f=1 mm. 

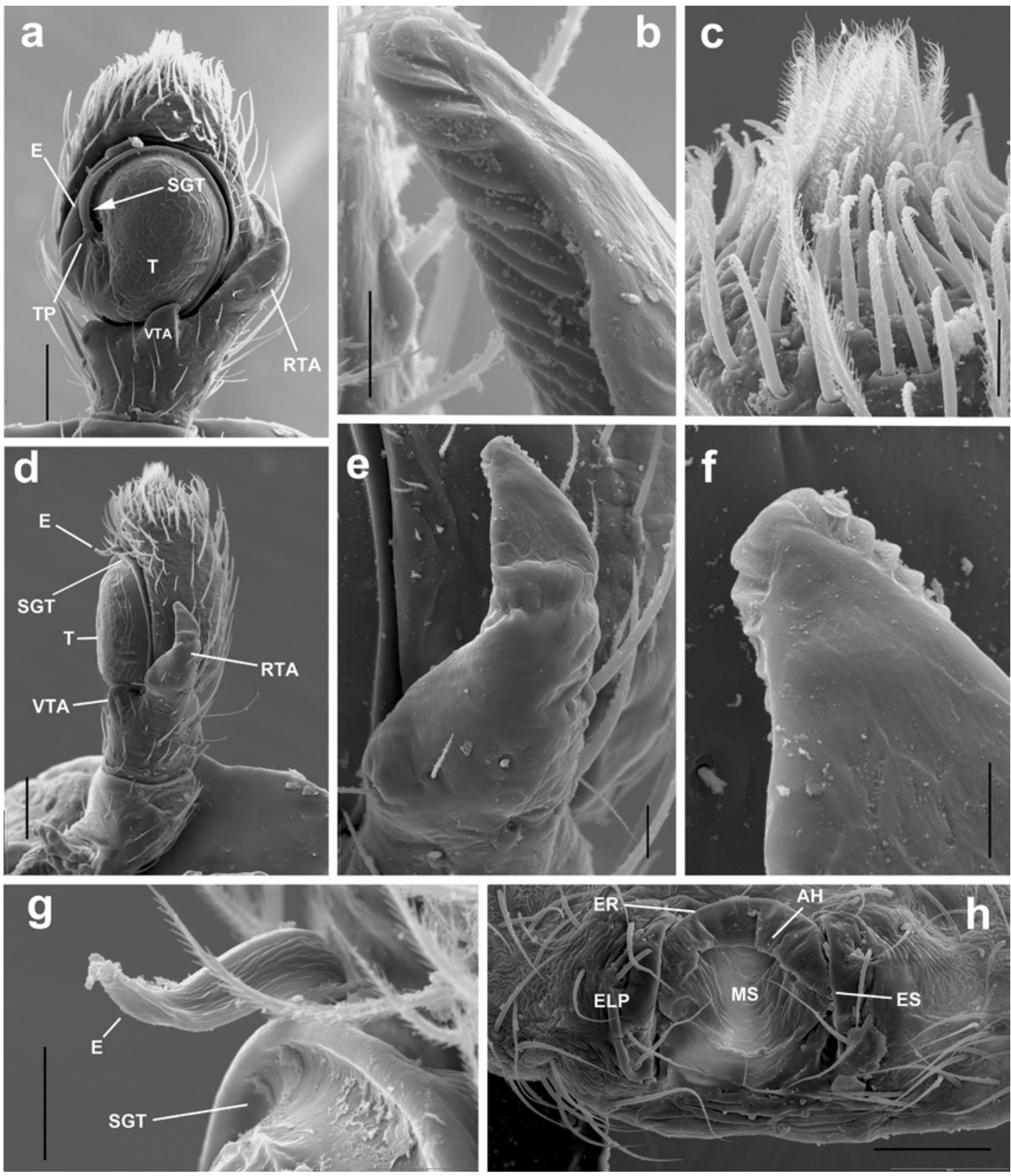

Fig. 4. Uraarachne runcinioides (Simon) n. comb., SEM of copulatory organs: a-g, male (MACN-Ar 19491); h, female (MACN-Ar 19491). a, left palp, ventral view, b, detail of the RTA ridges, c, cymbial apical patch of setae, $\mathrm{d}$, left palp, retrolateral view, e, same, RTA, f, same, detail of the RTA tip, g, embolus, close view, retrolateral, h, epigynum, ventral view. Scale bars: $\mathrm{a}, \mathrm{d}, \mathrm{h}=100 \mu \mathrm{m}, \mathrm{b}, \mathrm{f}=10 \mu \mathrm{m}, \mathrm{c}, \mathrm{e}, \mathrm{g}=20 \mu \mathrm{m}$. See abbreviations in the text.

Platyarachne argentina Mello-Leitão, 1944: 371

Two male syntypes from Argentina: Buenos Aires Province: Boulogne (S34³0'4.41', W58 34'1.80'), A. Prosen coll. Deposited in MLP 16190, examined. New synonymy.
Notes. In the vial of MNHN 4047 there are three specimens, one immature (herein considered the holotype, as the original description mentioned "pullus"), together with two conspecific adult females; we assumed that they were added later by the author, given that they were not mentioned 

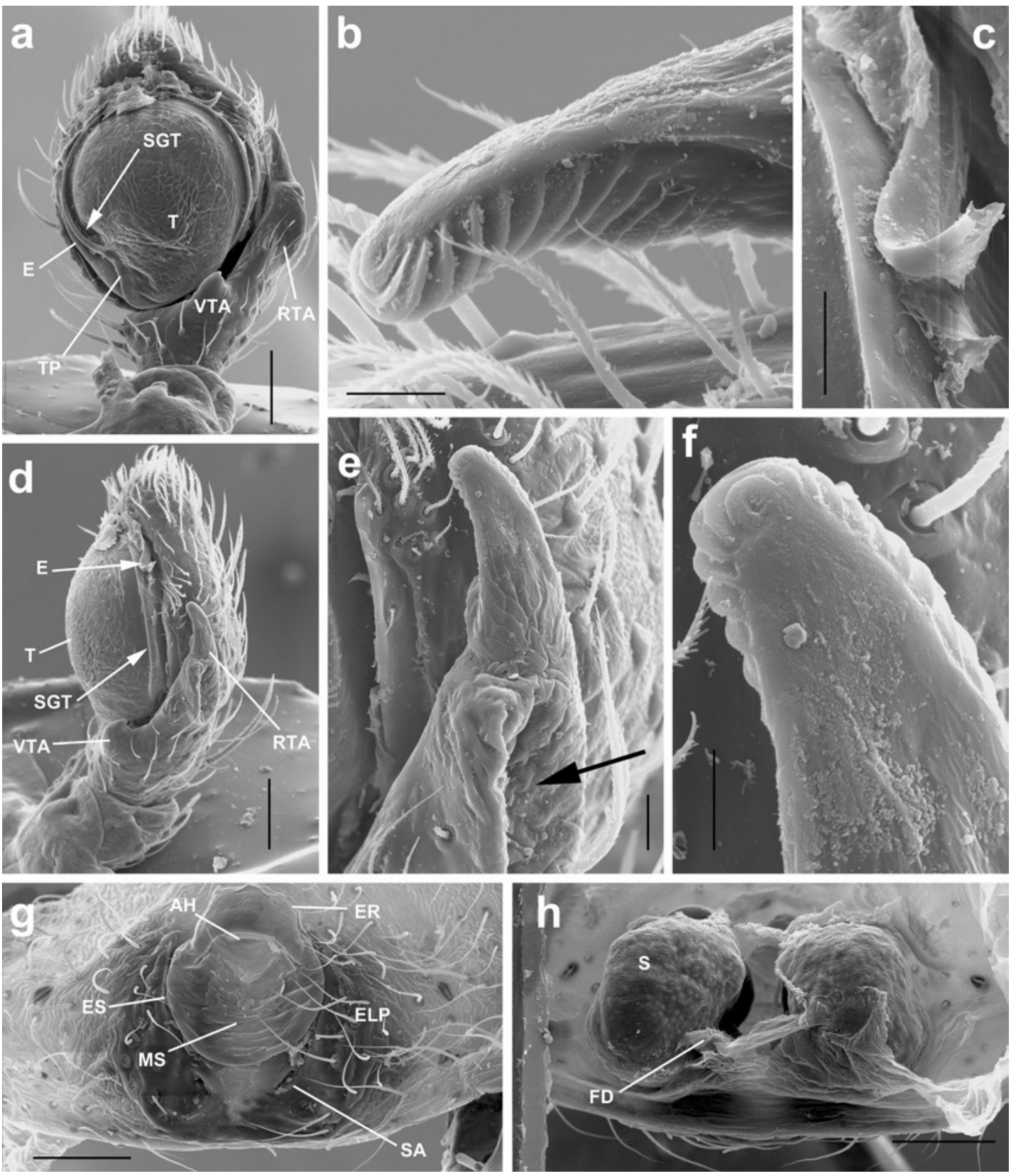

Fig. 5. Uraarachne cornuta (Simon) n. comb., SEM of copulatory organs: a-f, male (MACN-Ar 39360); g-h, female (MACN-Ar 36272). a, left palp, ventral view, b, detail of the RTA ridges, c, embolus, close view, retrolateral, $d$, left palp, retrolateral view, e, same, RTA (black arrow=membranous sector), f, same, detail of the RTA tip, g, epigynum, ventral view, $\mathrm{h}$, vulva, internal genitalia, dorsal view. Scale bars: $\mathrm{a}, \mathrm{d}, \mathrm{g}, \mathrm{h}=100 \mu \mathrm{m}, \mathrm{b}, \mathrm{f}=10 \mu \mathrm{m}, \mathrm{c}, \mathrm{e}=20 \mu \mathrm{m}$. See abbreviations in the text.

in the original description, and because is presumed that Simon filled type series subsequently with non-type material (see Dupérré \& Harms 2018: 18).

Synonymy. The male syntypes of Platyarachne argentina were examined and, although they lack the white pigment on the ocular area and other areas of cephalothorax, they show no significant differences in both body and genitalic morphology (see figs. 2c-e) from the males herein des- 
cribed as U. runcinioides. Concerning Erissoides argentinus, although we did not examine the type (since it was not located in the MNRJ, see Silva-Moreira 2010), the description corresponds well with that of $U$. runcinioides. On the other hand, the type locality ("Rosas"), and the collector mentioned in the text (J. Daguerre), are coincident with those of the largest series of this species located at MACN (see below). Further, according to Mello-Leitão (1931) the source of the material of his paper was sent, in part, by Emilio Gemignani, who worked at MACN in the 1930's; this could explain why there are many specimens with the same data, suggesting that Gemignani sorted one or a few specimens to send to Brazil. Finally, Mello-Leitão mentioned that the type specimen was obtained in a nest of Sceliphron figulum (currently $S$. asiaticum, Hymenoptera: Crabronidae) hunting wasps. Again, although this information is not in the MACN labels, the very large series of P. runcinioides from this locality are consistent with a single collection event, highly probably, from the above mentioned wasp nests. Diagnosis. This species resembles U. kapiity n. sp. in carapace shape (with moderate lateral ocular protrusions and the abdomen longer than wide, posteriorly truncated); but differs by having a less elongated general body (especially with abdomen more widened posteriorly, Fig. 10a); females have larger anterior hood and more separated spermathecae (Fig. 10h, i), and males are recognized by the smaller bulb, thinner embolus, and by the ventral expansion of the RTA in more basal position (Figs 11 i-j, 23a-b, 25a-b).

Description. Female (MACN-Ar 19491, voucher CJG-1801, Fig. 10). Coloration (in ethanol): carapace yellowish brown, with a longitudinal wide, white stripe at middle with thinner white stripes forwardly, to the eye region, which is also white; endites, labium, and sternum yellowish brown, chelicerae yellowish with small sparse white dots; legs yellowish, with longitudinal white areas on I-II. Abdomen mostly yellowish white, with light brown stripes along marginal folds, especially on the caudal area, three pairs of dark spots (corresponding to the dorsal apodemes); ventrally mostly whitish, with pale yellow lateral folds converging along the midline. Measurements. Body length 4.48, prosoma length 1.84, width 1.76 , opistosoma lenght 2.80 , maximum width 2.42, legs: length of articles (femur, patella, tibia, metatarsus, tarsus, total): I $2.36,1.04,1.70,1.70$, $0.70,7.50$; II $2.30,1.02,1.52,1.58,0.70,7.12$; III $0.90,0.50,0.56,0.44,0.36,2.76$; IV 1.06, 0.50, $0.58,0.46,0.30,2.90$. Prosoma flattened, longer than wide, with short blunt setae. Eyes small, the region between ALE and PLE protuberant, eye diameters and interdistances: AME 0.04, ALE 0.08, PME 0.03, PLE 0.04, AME-AME 0.22, AME-ALE 0.18, PME-PME 0.32, PME-PLE 0.38 . Labium as long wide (length 0.24 /width 0.24 ), sternum longer than wide (length 0.96 / width 0.74). Abdomen trapezoidal, truncated anteriorly, widened posteriorly (anterior width 1.24). Leg spination: I: tibia V1-2-2-2 metatarsus V1-2-2-2-2-2-2; II: tibia V0-2-2-2, metatarsus V1 (very small)-2-2-2-2-2-2; metatarsus III and IV with an apical verticillum o small spines.

Genitalia. Anterior hood relatively wide, epigynal sutures slightly curved, copulatory openings inconspicuous (Fig. 10h), spermathecae nearly reniform, separated by nearly their radius (Fig. 10i). Male (MACN-Ar 19491, voucher CJG-1800, Fig. 11). Color in ethanol as in female except by the following: background of all body light brown, and with less extension of the white pigment on the carapace, legs, and abdomen; most surface of metatarsi I-II and distal part of tibiae I-II darkened. Measurements. Body length 3.52, prosoma length 1.50 , width 1.40 , opistosoma lenght 2.22 , maximum width 1.48 , legs: lenght of articles (femur, patella, tibia, metatarsus, tarsus, total): I $2.80,0.94,2.22,2.18,0.88,9,02$; II $2.60,0.86$, $1.98,1.92,0.82,8.18$; III $0.82,0.46,0.54,0.46$, $0.30,2.58$; IV $0.88,0.50,0.52,0.52,0.38,2.80$. Leg formula I-II-IV-III. Eyes small, the region between ALE and PLE protuberant, eye diameters and interdistances: AME 0.04, ALE 0.04, PME 0.04, PLE 0.04, AME-AME 0.14, AME-ALE 0.12, PME-PME 0.24, PME-PLE 0.22. Labium as long as wide (lenght 0.24 /width 0.24 ), sternum heart shaped, nearly as long as wide (lenght $0.68 /$ width 0.64). Abdomen nearly rectangular, truncated anteriorly, with posterolateral extensions, widened posteriorly (anterior widht 0.96 ). Leg spination: I: femur D1-1-1, tibia V0-2-2-2 (very thin), metatarsus V0-2-2-2-2 (very thin), II: femur D1-1-1-1, tibia V0-2-2-2 (very thin), metatarsus V0-2-2-2-2 (very thin) III: femur D0-1-11-1-1 (in a zigzagging row), IV: femur D1-1-0-1 (slightly displaced to prolateral). Metatarsi III and IV with an apical verticillum o small spines. Genitalia: palp with relatively elongated and slightly sinuous RTA, with a ventral expansion relatively basal (Fig. 25a-b); bulb discoidal, medium sized, with embolus origin at nearly ten o'clock position.

Other material examined. ARGENTINA: Buenos Aires Province: Tigre: Tigre, (S34 $25^{\prime} 33.12$ ', W58 $34^{\prime} 46.36^{\prime \prime}$ ), no date, M. 

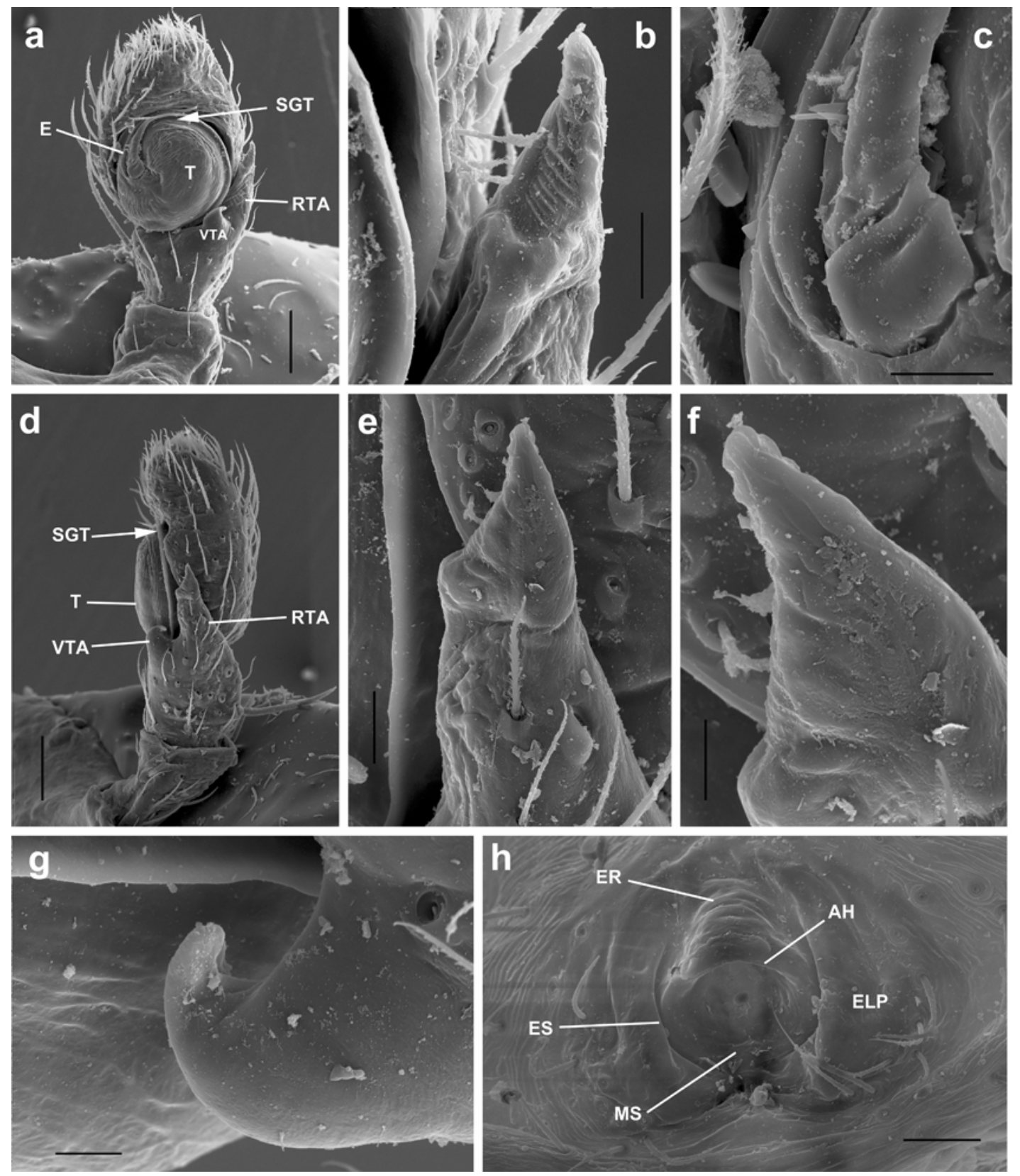

Fig. 6. Runcinia grammica Simon, SEM of copulatory organs: a-g, male (SMF 21877); h, female (SMF 21877). a, left palp, ventral view, b, detail of the RTA ridges, c, embolus base, close view, retrolateral, d, left palp, retrolateral view, e, same, RTA, f, same, detail of the RTA tip, g, VTA, retrolateral view, h, epigynum, ventral view. Scale bars: $\mathrm{a}, \mathrm{d}=100 \mu \mathrm{m}, \mathrm{b}, \mathrm{c}, \mathrm{e}=20 \mu \mathrm{m}, \mathrm{f}, \mathrm{g}=10 \mu \mathrm{m}, \mathrm{h}=50 \mu \mathrm{m}$. See abbreviations in the text.

Birabén coll. 3 ㅇ (MACN-Ar 19343); Vicente López: Vicente López, (S34³2'21.29', W58²8'25.35'), no date, no collector, 19 (MACN-Ar 19346); La Matanza: Lomas del Mirador, (S34 40 '1.15", W58³1'47.36"), II.1992, C. Grismado coll. 1j (MACN-Ar 19340); Esteban Echeverría: Monte
Grande, (S3449'37.84”, W58 27'43.24'), 15.XII.1931, Escur-Daguerre \& de Carlo coll. 1j (MACN-Ar 19412); Quilmes: Quilmes, (S3443'14.28', W58¹5'16.58'), no date, J. Viana coll. 10', 1j (MACN-Ar 39081); La Plata: La Plata, S3455'22.09”, W 5757'12.16”), no date, 

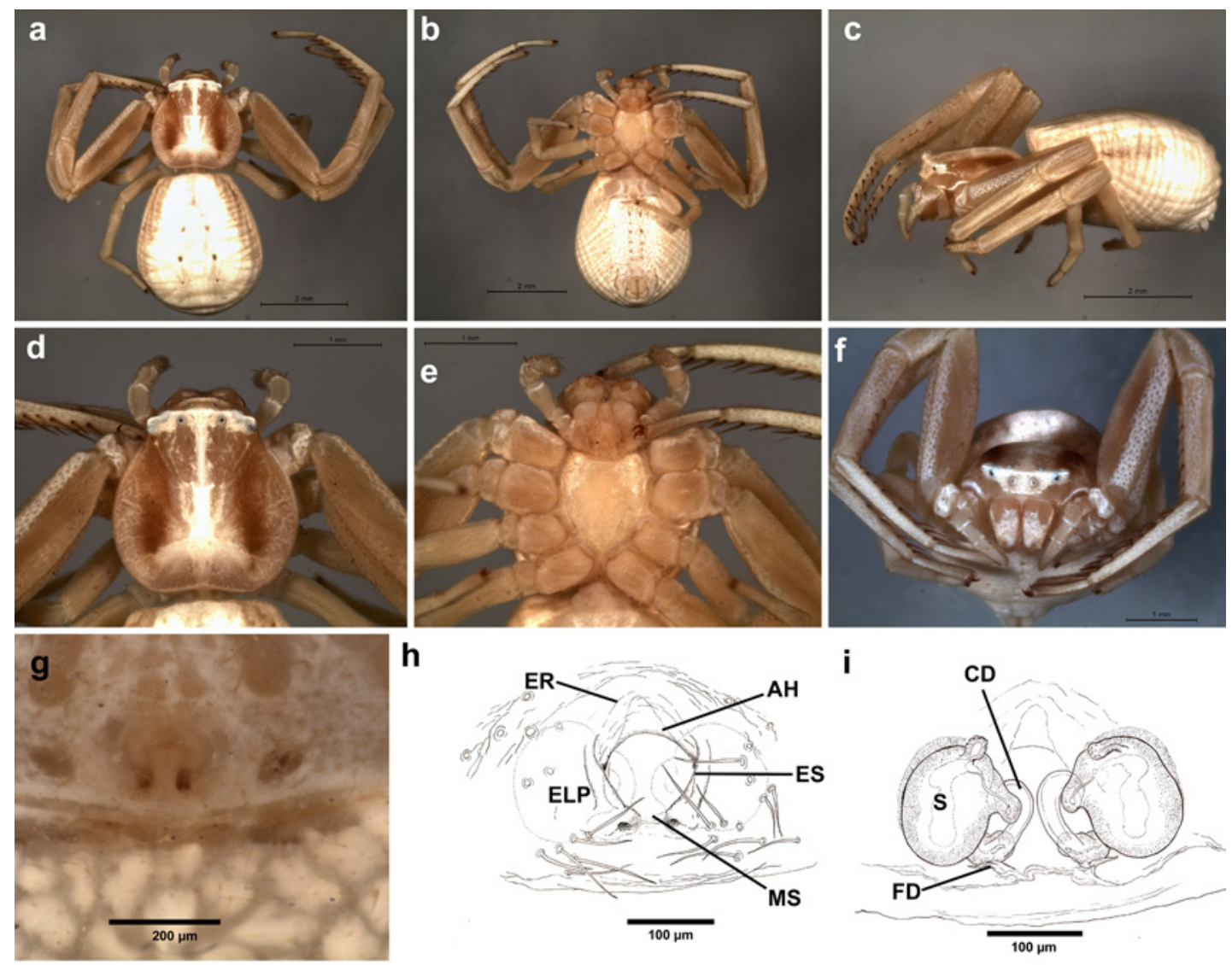

Fig. 7. Runcinia grammica Simon, female (SMF 21877); a, habitus dorsal, b, same, ventral, c, same lateral, d, carapace, dorsal view, e, same, ventral, f, habitus, anterior view, g-h, epigynum, ventral view, i, internal genitalia, cleared, dorsal view. See abbreviations in the text.

no collector, 2 ㅇ (MLP 18538); Carlos Casares: Carlos Casares, (S35³7'21.30', W6121'55.28'), 25.XII.1978, (probably P. Goloboff by calligraphy in labels), 19 (MACN-Ar 19176), same locality and collector, literal date: "summer 1978-79", 1 (을 (MACN-Ar 19201); Chascomús: Chascomús, (S35³4'39.62', W58 0'49.13”), no date, leg. J. Daguerre, 2j (MACN-Ar 19389); Las Flores: Rosas, Estación del Ferrocarril General Roca, (S35 58'0.00", W58 $\left.56^{\prime} 23.00^{\prime \prime}\right)$, no date, J. Daguerre coll. 10 (MACN-Ar 19345); 100 (MACN-Ar 18672); 3 (MACN-Ar 19114, ex 36840); same locality, no data of collector (presumably J. Daguerre by calligraphy in labels), 4o', 3\%, 12j (MACN-Ar 19348), 2 (MACN-Ar 19347), 1 (ㅇ (MACN-Ar 19502), 30 ${ }^{*}, 149,124 \mathrm{j}$ (MACN-Ar 19491, vouchers CJG 1752, 1800, 1801), 25 ㅇ (MACN-Ar 19417), 209 (MACNAr 19390), 4o', 19, 16j (MACN-Ar 19451), 1j (MACN-Ar 362); Las Flores, (S36 0'50.97', W59 $\left.{ }^{\circ} 5^{\prime} 57.47^{\prime \prime}\right)$, no collector data, illegible label:
29.VIII.1942(?), 19 (MACN-Ar 19530), same locality, no collector,no date, 22 (MACN-Ar 19355), 5 (MACN-Ar 19414), 16 ㅇ (MACN-Ar 19361); General Pueyrredón: Airport of Camet (currently Astor Piazzolla International Airport), near Mar del Plata (S37 $\left.56^{\prime} 03^{\prime \prime}, \mathrm{W} 57^{\circ} 34^{\prime} 24^{\prime \prime}\right)$, 31.X.1984, J. Farina coll. 10, 1ㅇ (MMPE); same locality and collector, 21.XI.1984, 2\% (MMPE); Entre Ríos Province: no data, probably Concordia (S31 23 '29.01", W 58 1'2.76”), literal label: "Ex Col. Birabén, Number 2 bis"), 59 (MLP 18432, together with one specimen of $U$. kapiity). DOUBTFUL RECORDS: "Pampa Grande" (Salta Province?) (S25 52'5.25”, W65 30'26.47”), 15.XI.1898, no collector, 1우 (MACN-Ar 40242, ex 19432); no locality, no date, no collector, $10^{*}$ (MACN-Ar 19535), 1j(MACN-Ar 19119, ex 36829).

Distribution. Uruguay and Eastern Argentina (Buenos Aires and Entre Ríos Provinces, with one doubtful record in Salta Province, probably mislabeled, Map 1). 

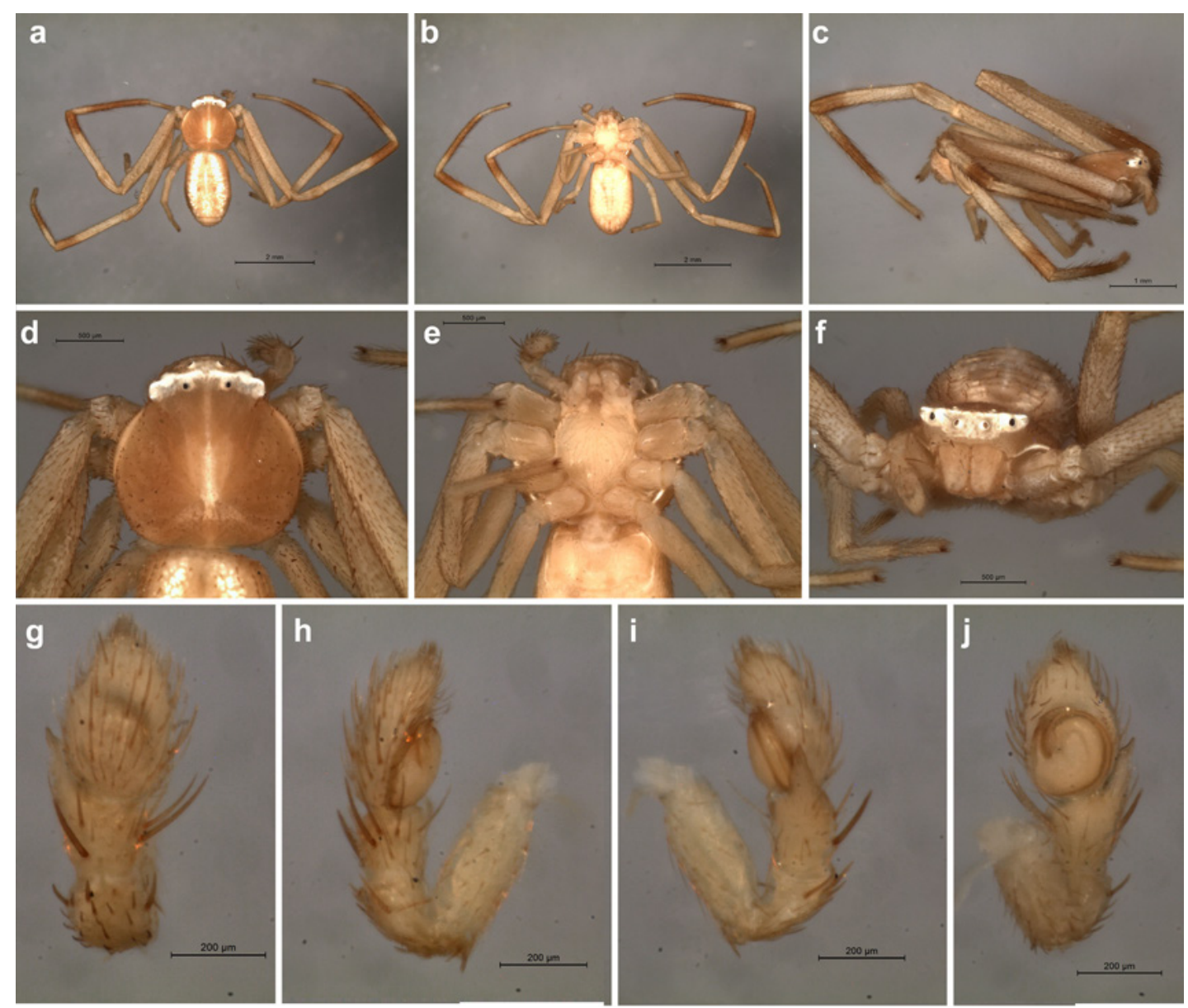

Fig. 8. Runcinia grammica Simon, male (SMF 21877); a, habitus dorsal, b, same, ventral, c, same lateral, d, carapace, dorsal view, e, same, ventral, f, same, anterior, g-j, left palp, g dorsal view, h, prolateral, i, retrolateral, j, ventral.

\section{Uraarachne variegata (Mello-Leitão, 1941) new combination}

(Figs. 2f-h, 12, 13, 23e-f, 25e-f, 27b-c , Map 2)

Misumenoides variegatus Mello-Leitão, 1941: 218, f. 28-29. Male holotype from Argentina: Santa Fe Province: Reconquista, (S29 ${ }^{\circ}$ '41.35', W59³8'36.69"), XI-1939, M Birabén coll. Deposited in MLP 15229, examined. Roewer 1955: 843.

Diagnosis. Females of $U$. variegata are somatically similar to those of $U$. brevipes in having a similar color pattern on carapace, with lateral paraxial dark bands, and a relatively short abdomen (Fig, 12) but differ by the less remarkable protrusions on the ALE, by the abdomen less angular, and by the epigynum with a very wide median septum. Males have the palps very similar to those of $U$. runcinioides, but are also recognizable by the color pattern (similar to the female, but more contrasting, Fig. 13), by the shallow ALE protrusions, and by the abdomen not caudally truncated.

Description. Female (MACN-Ar 33583, voucher CJG-1742, Fig. 12). Coloration (in ethanol): carapace pale brown, with two paraxial darkened bands, and three thinner white stripes forwardly, to the ocular area from the fovea; contrasting white pigment on a transverse band around the eyes; endites, labium, and sternum pale yellowish, chelicerae yellowish with small sparse brown dots; legs pale brown, with longitudinal white areas on I-II. Abdomen with a complex dorsal pattern of white guanine pigment on brownish background, with a light brown cardiac area and two pairs of dark brown, diagonal markings on the posterior part; white stripes along marginal folds, especially on the caudal area; ventrally mostly whitish, with pale yellow lateral folds 

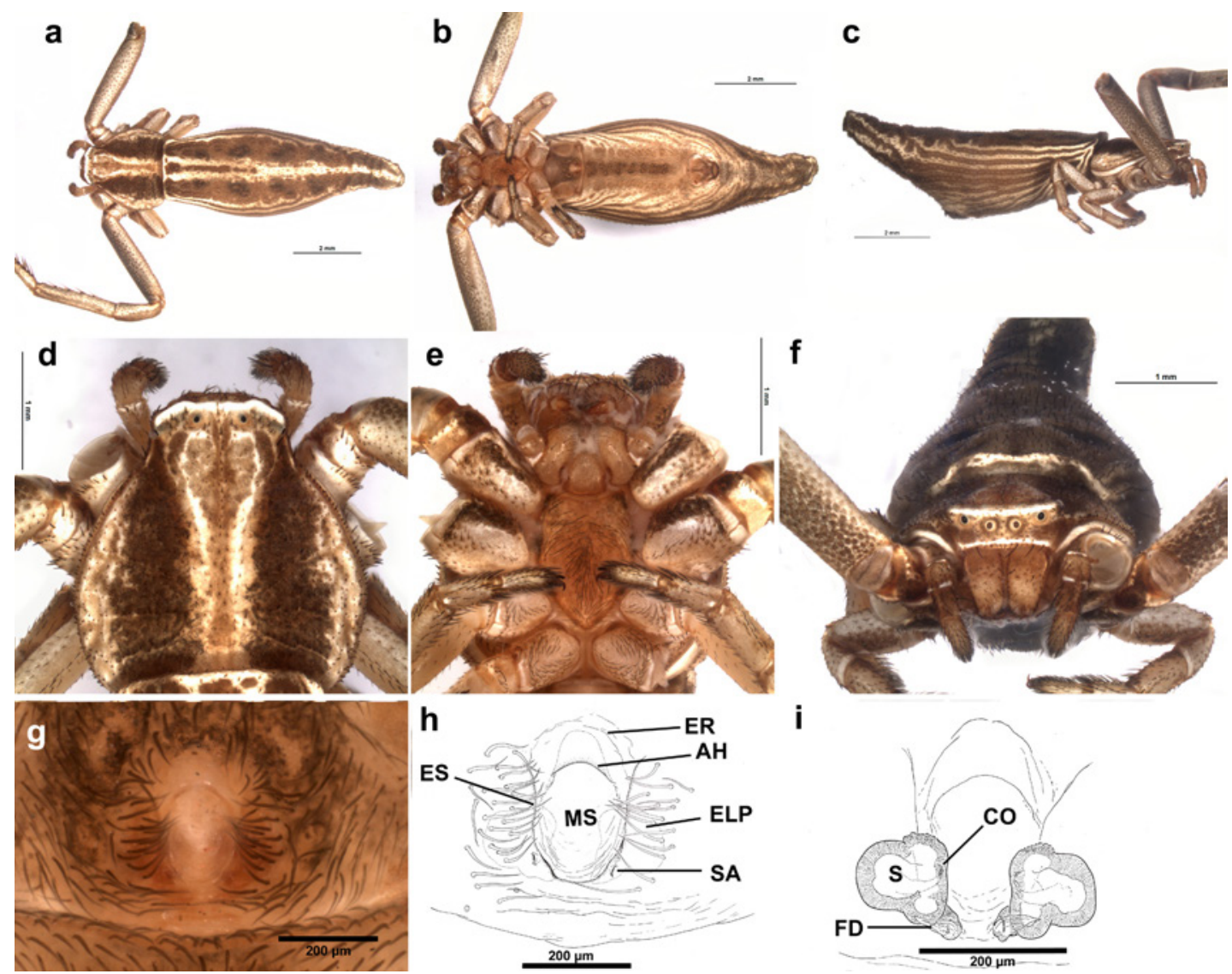

Fig. 9. Uraarachne longa Keyserling, female from Paraguay (MNHNP [IBNP-Invert.-JAK-CR-2556]); a, habitus dorsal, b, same, ventral, c, same lateral, d, carapace, dorsal view, e, same, ventral, f, habitus, anterior view, g-h, epigynum, ventral view, i, internal genitalia, cleared, dorsal view. See abbreviations in the text.

converging along the midline. Measurements. Body length 4.88, prosoma length 2.10 , width 2.04 , opistosoma length 2.92 , maximum width 2.48, legs: length of articles (femur, patella, tibia, metatarsus, tarsus, total): I 2.48, 1.12, 1.84, $1.76,0.82,8.02$; II $2.36,1.04,1.64,1.50,0.72$, 7.26; III 1.12, 0.60, 0.76, 0.58, 0.44, 3.50; IV 1.32, $0.54,0.82,0.66,0.44,3.78$. Prosoma not flattened, longer than wide, with sparse short blunt setae. Eyes small, the region between ALE and PLE only slightly protuberant, eye diameters and interdistances: AME 0.06, ALE 0.10, PME 0.06, PLE 0.08, AME-AME 0.22, AME-ALE 0.18, PME-PME 0.32, PME-PLE 0.30. Labium as long as wide (length $0.36 /$ width 0.34 ), sternum longer than wide (length 1.14/width 0.90). Abdomen not very elongated, slightly widened posteriorly (anterior widht 1.60) and caudally rounded. Leg spination: I: femur P1 (subbasal), tibia V0-2-2-2 metatarsus V2-1-2-2-2-2-2; II: femur D1 (very small), tibia V0-2-2-2, metatarsus V1-2-2-2-2-2-2,
III: femur D1 (small, subbasal); metatarsus III and IV with an apical verticillum o small spines. Genitalia: Anterior hood relatively narrow, epigynal sutures curved; median septum nearly circular, laterally expanded (but lesser than in $U$. cornuta), copulatory openings inconspicuous; posterior holes corresponding with the spermathecal apodemes (Fig. 12h), spermathecae ovoid, separated from each other by nearly their radius (Fig. 12i).

Male (MACN-Ar 38178, voucher CJG-1897, Fig. 13). Color as in female except by the following: margin of carapace reddish brown, with a brown line along the dorsal midline, chelicerae with brown pigment concentrated on basal and distal third of the frontal surface; most surface of metatarsi I-II and distal part of all tibiae, patellae and metatarsi darkened, also with dark markings on the ventral surface of all femora; abdomen with similar pattern but with larger extensions pigmented with dark brown, especially at sides, 

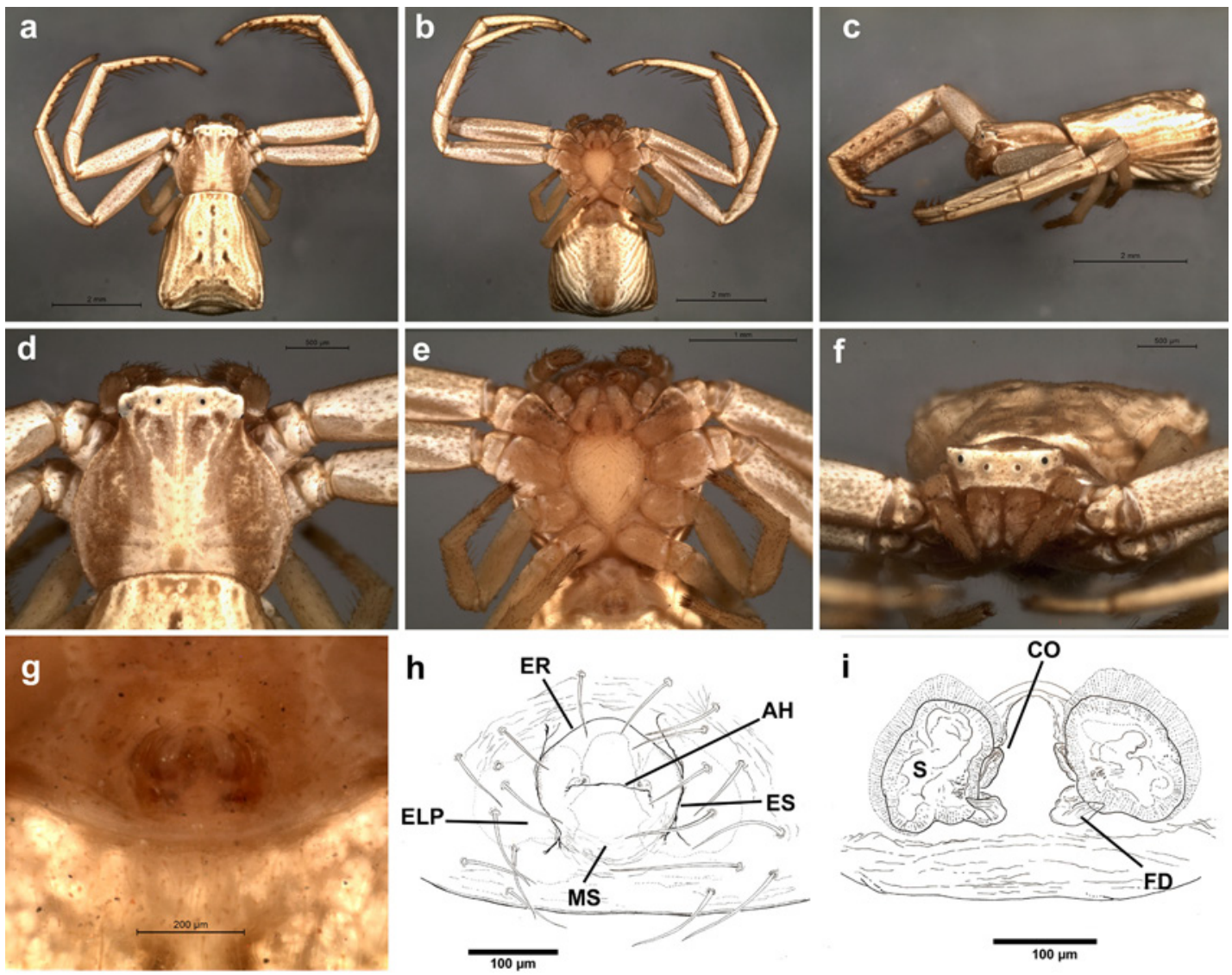

Fig. 10. Uraarachne runcinioides (Simon) n. comb., female (MACN-Ar 19491); a, habitus dorsal, b, same, ventral, c, same lateral, d, carapace, dorsal view, e, same, ventral, f, habitus, anterior view, g-h, epigynum, ventral view, i, internal genitalia, cleared, dorsal view. See abbreviations in the text.

showing a continuous lateroventral dark band (Fig. 13b). Measurements. Body length 2.84, prosoma length 1.34 , width 1.34 , opistosoma lenght 1.58 , maximum width 1.28 , legs: lenght of articles (femur, patella, tibia, metatarsus, tarsus, total): I 1.80, 0.72, 1.48, 1.36, 0.60, 5.96; II 1.60, $0.62,1.18,1.12,0.56,5.08$; III $0.74,0.40,0.50$, $0.40,0.30,2.34$; IV $0.78,0.36,0.56,0.42,0.36$, 2.48. Leg formula I-II-IV-III. Eyes small, the region between ALE and PLE protuberant, eye diameters and interdistances: AME 0.04, ALE 0.08, PME 0.04, PLE 0.06, AME-AME 0.14, AME-ALE 0.12, PME-PME 0.22, PME-PLE 0.20. Labium as long as wide (lenght 0.22 /width 0.20 ), sternum heart shaped, nearly as long as wide (lenght 0.68 / width 0.66 ). Abdomen nearly elongate pentagonal, truncated anteriorly, more pointed than in female (anterior widht 0.86). Leg spination: I: femur D1-1-0-1-1-0-1, P1 (small, subbasal), tibia V0-2-2-2 (very thin), metatarsus V0-2-2-2-2 (very thin), II: femur D1-1-1, tibia V0-2-2-2 (very thin), metatarsus V0-2-2-2-2 (very thin) III: femur D01-1-1-0-1 (in a zigzagging row), IV: femur D0-11-0. Metatarsi III and IV with an apical verticillum o small spines.

Genitalia: palp with relatively elongated and slightly sinuous RTA, with a ventral expansion less conspicuous than in other species; bulb discoidal, medium sized, with embolus origin at nearly ten o'clock position (Figs. 13 g-j, 23e-f, 25e-f).

Other material examined. PARAGUAY: Itapúa Department: "entre Cnel. Bogado y Gral. Artigas: San Miguel Potrero: cauce del Arroyo Kamba'y", (S27¹'59.88', W56 16 ' 59.87'), 17.I.1996, in mature grassland in the marsh, J.A. Kochalka coll., sweeping net, $10^{\top}$ (MNHNP [IBNP-Invert.-JAK-CR-2550]); ARGENTINA: Corrientes Province: San Martin: Aguapey (locality not found, probably Aguapey river), XI.1941, M. Birabén coll. 19, 1j (MLP 18566), same collector, XII.1941, 50', 3j (MLP 18550, together one specimen of $U$. 

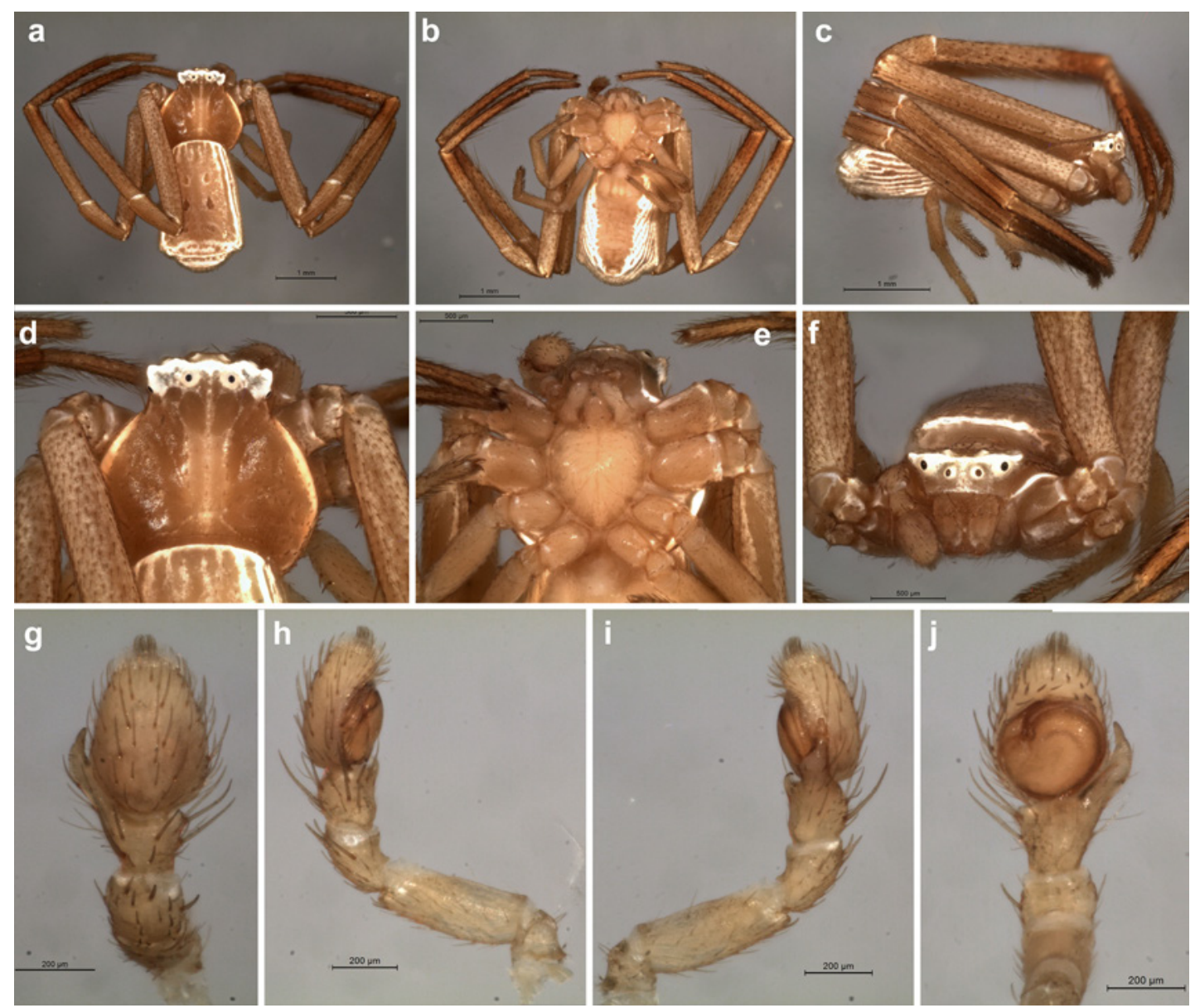

Fig. 11. Uraarachne runcinioides (Simon) n. comb., (MACN-Ar 19491); a, habitus dorsal, b, same, ventral, c, same lateral, d, carapace, dorsal view, e, same, ventral, f, same, anterior, g-j, left palp, g dorsal view, h, prolateral, $\mathrm{i}$, retrolateral, $\mathrm{j}$, ventral.

kapiity); Mercedes: Mercedes, (S29 $11^{\prime} 4.50^{\prime \prime}$, W584'24.86'), IV.1941, M. Birabén coll. 1j (MLP 18556); Santa Fe Province: Garay: Colonia Mascías, (S3048'14.16”, W60²'20.77'”), XI.1942, Exc. J. Viana, 19, 2j (MACN-Ar 40467);

Buenos Aires Province: San Pedro: San Pedro, (S3340'32.82', W59³9'46.32'), 2.XI.1991, M. Ramírez coll. 1 subadult $\$$ (MACN-Ar 18737); San Isidro: Acassuso: Reserva Municipal Refugio Natural Educativo Ribera Norte, Sauzal, S34 28'2.24", W58²9'37.14" (GPS, +-7m), elev. 7 m, 28.XI.2014, R. Rodríguez Landó \& L. Rodríguez Demarco coll., beating foliage, 1 ㅇ (MACN-Ar 33583, voucher CJG-1742); La Plata: La Plata, (S34 $\left.55^{\prime} 13.78^{\prime \prime}, \quad W 57^{\circ} 57^{\prime} 12.84^{\prime \prime}\right)$, no date, no collector, 19 (MLP 18538); Mar Chiquita: Estancia Nahuel Rucá (37 $37^{\circ} 00.5^{\prime \prime} \mathrm{S}$ 57 25'24.6'W), 29-30.XI.2018, L. Peralta coll.,1 \% (MMPE); Ciudad Autónoma de Buenos
Aires: Reserva Ecológica Costanera Sur: coast of Río de la Plata, (S34³6'24.19”, W58²0'45.68”'), 19.I.2016, floating vegetation raft, L. Zapata coll., hand collecting, 1 ( MACN-Ar 39325), "Laguna de los Patos", eastern margin, (S34 '36'31.42", W58 21'12.13”), elev. 4 m (GPS), 29.X.2017, on Typha latifolia, on the water, L. Piacentini \& M. Ramírez coll., night collecting, 10 (MACN-Ar 38178, voucher CJG-1897), same locality, margin SE, S34 36'56,5” W58 21'10,3”, 03.X.2019, L. Zapata coll., beating on Typha latifolia, 1 우 (MACN-Ar 41771, voucher CJG-1978).

Distribution. Paraguay and Eastern Argentina (Corrientes, Santa Fe and Buenos Aires, Map 2).

Uraarachne kapiity, new species (Figs. 14, 15, 23g-h, 25g-h, 27a, Map 5)

Type material. Male holotype from Argentina: 

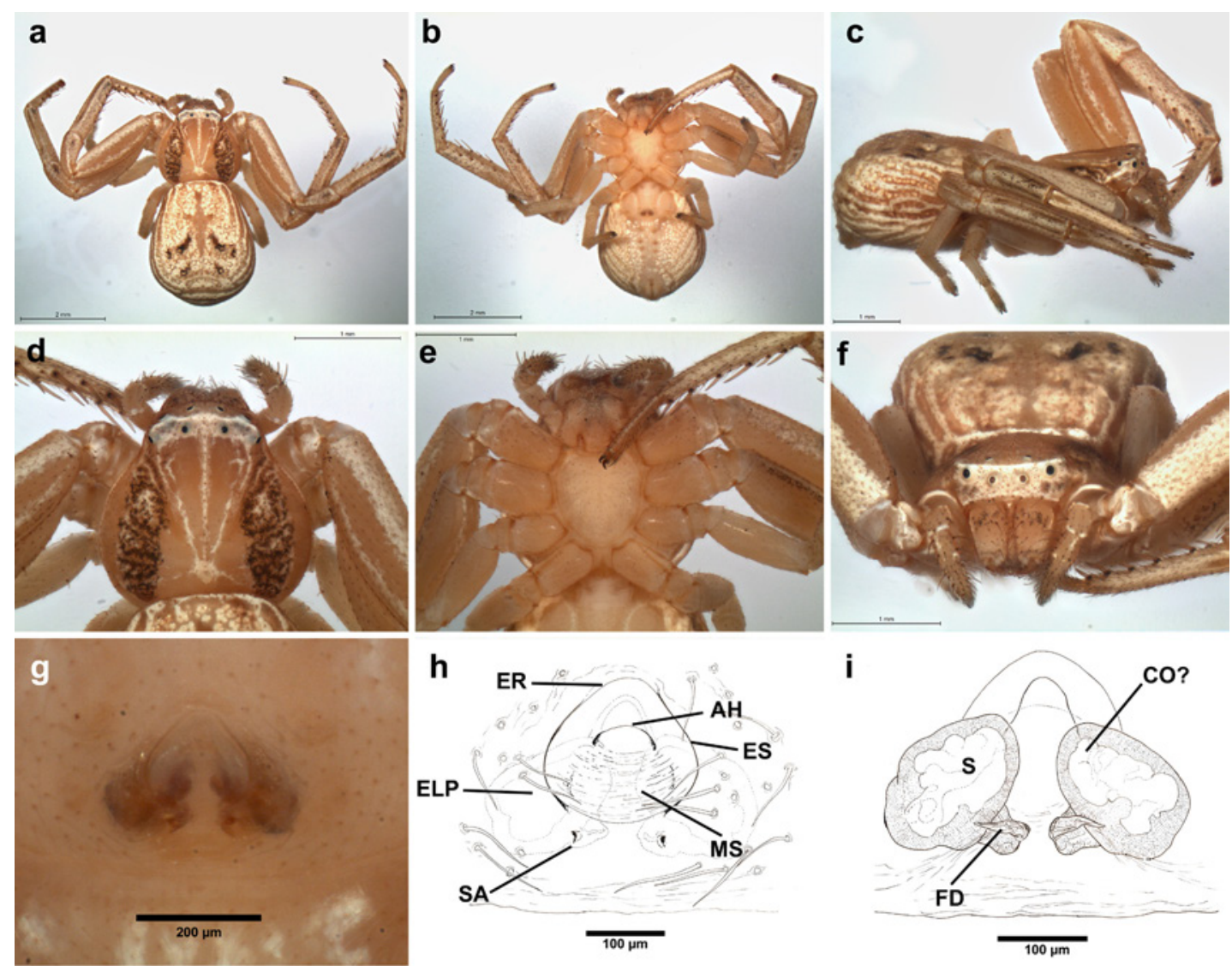

Fig. 12. Uraarachne variegata (Mello-Leitão) n. comb., female (MACN-Ar 33583); a, habitus dorsal, b, same, ventral, c, same lateral, d, carapace, dorsal view, e, same, ventral, f, habitus, anterior view, g-h, epigynum, ventral view, i, internal genitalia, cleared, dorsal view. See abbreviations in the text.

Chaco Province: San Fernando: Basail, S274'ㄴ.92.', W59¹3'41”, 19.XI.2014, G. Ávalos coll., grassland, deposited in MACN-Ar 39681 (voucher CJG-1815). Two male paratypes, same data as the holotype, deposited in CARTROUNNE 9233; female paratype from San Fernando: Estancia La Querencia, S27 $44^{\prime} 40.56^{\prime \prime}$, W59 10 '17.5”, 16.XI.2015, G. Ávalos coll., grassland, deposited in MACN-Ar 39681 (voucher CJG-1814).

Diagnosis. Both sexes resemble to those of $P$. runcinioides, in coloration, carapace shape (with moderate lateral ocular protrusions and the abdomen longer than wide and posteriorly truncated), but differs by having a more elongated general body, with a nearly rectangular abdomen, less widened caudally (Fig. 14, 15). Females are also recognized by the anterior hood shallow, and spermathecae closer to each other, and males by the larger bulb, a thicker embolus, and by the ventral expansion of the RTA in more apical po- sition (Figs. 23g-h , 25g-h).

Description. Female (MACN-Ar 39680, voucher CJG-1814, Fig. 14). Coloration (in ethanol): carapace pale brown, with a longitudinal diffuse, white band at middle with thinner white stripes forwardly to the eye region, which has a very thin transverse white band; endites, labium, and sternum lighter, chelicerae almost uniformly pale brown; legs pale brown, with longitudinal white areas on I-II. Opisthosoma mostly whitish, with three pairs of dark spots (corresponding to the dorsal apodemes); ventrally mostly whitish, with lateral folds converging along the midline, pale brown. Measurements. Body length 5.81, prosoma length 2.26 , width 2.08 , opistosoma lenght 3.24, maximum width 2.00. Legs: length of articles (femur, patella, tibia, metatarsus, tarsus, total): I 2.44, 1.10, 2.04, 1.98, 0.76, 8.32; II 2.28, $1.16,2.04,1.68,0.76,7.92$; III $1.02,0.58,0.76$, $0.50,0.38,3.24$; IV $1.36,0.54,0.80,0.64,0.40$, 3.74. Prosoma flattened, longer than wide, with 

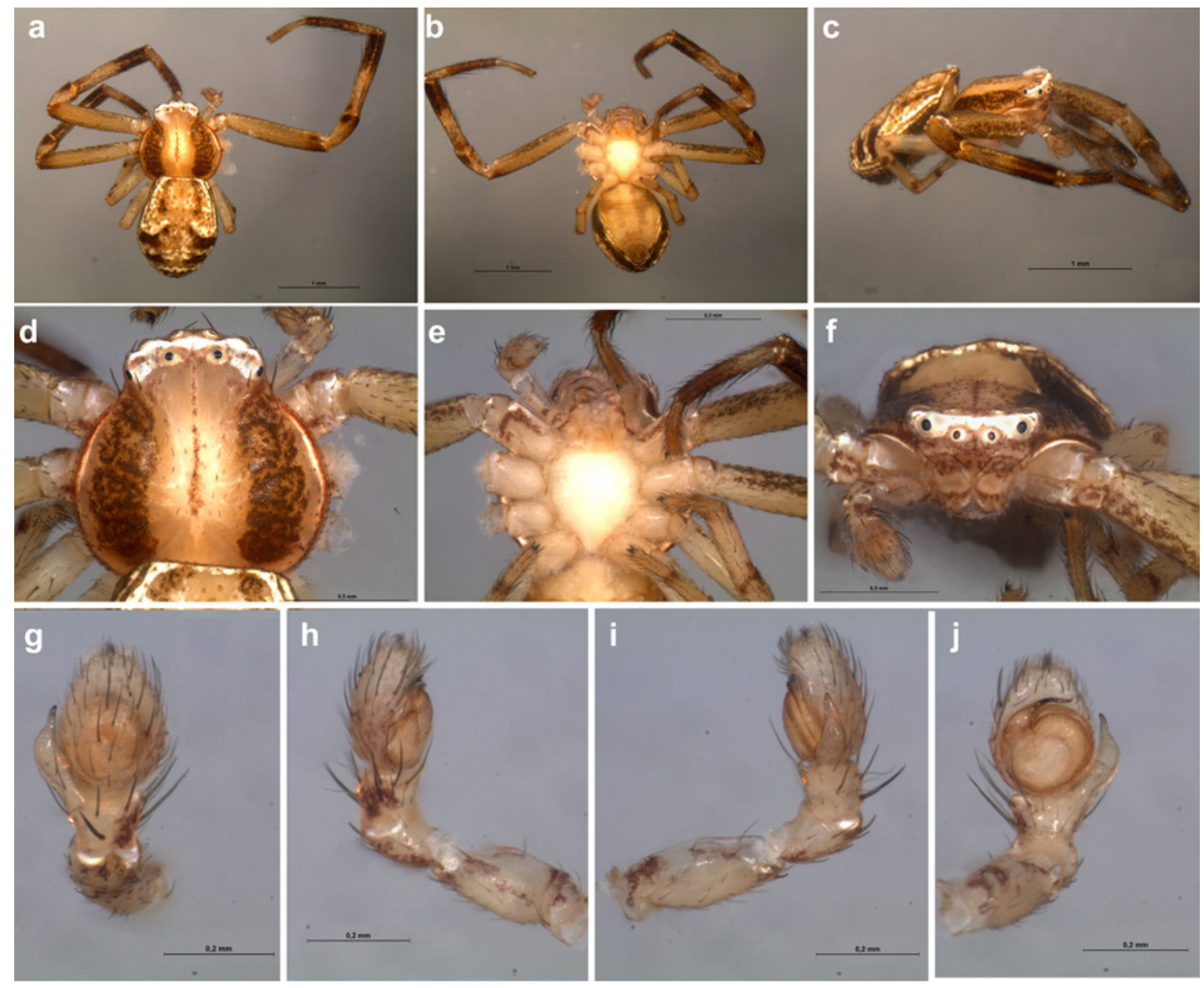

Fig. 13. Uraarachne variegata (Mello-Leitão) n. comb., male (MACN-Ar 38178); a, habitus dorsal, b, same, ventral, c, same lateral, d, carapace, dorsal view, e, same, ventral, f, same, anterior, g-j, left palp, g dorsal view, h, prolateral, i, retrolateral, j, ventral.

short blunt setae. Eyes small, the region between ALE and PLE acutely protuberant, eye diameters and interdistances: AME 0.06, ALE 0.10, PME 0.05, PLE 0.05, AME-AME 0.16, AME-ALE 0.20, PME-PME 0.32, PME-PLE 0.34. Labium as long wide (length 0.34 /width 0.34 ), sternum longer than wide (length 1.04/width 0.76). Abdomen nearly rectangular, truncated anteriorly, slightly widened posteriorly (anterior widht 1.48). Leg spination: I: tibia V0-2-2-2-2 metatarsus V1-2-22-2-2; II: tibia V0-2-2-2-2, metatarsus V1/2-2-2$2-2$; metatarsus III and IV with an apical verticillum of small spines.

Genitalia. Anterior hood shallow, hardly visible, remarkably narrow, epigynal sutures curved; median septum narrow, copulatory openings inconspicuous; spermathecal apodemes not visible (Fig. 14h), spermathecae relatively large, reniform, very close each to other (Fig. 14i).

Male (MACN-Ar 39681, voucher CJG-1815, Fig.
15). Color (in ethanol) as in female except by the following: background of all body light brown and with wider extension of the white pigment on the ocular area; surface of metatarsi I-II and distal part of tibiae I-II mostly darkened. Abdomen with similar pattern but with larger extensions pigmented with dark brown, at sides, showing a continuous lateroventral dark band (Fig. 15b). Measurements. Body length 4.12, prosoma length 1.74 , width 1.70 , opistosoma lenght 2.38, maximum width 1.30 , legs: lenght of articles (femur, patella, tibia, metatarsus, tarsus, total): I 2.76, 1.20, 2.34, 1.90, 0.80, 9.00; II $2.48,1.10,1.98,1.58,0.76,7.90$; III $0.98,0.46$, $0.60,0.48,0.34,2.86$; IV 1.14, 0.50, 0.62, 0.48, $0.34,3.08$. Leg formula I-II-IV-III. Eyes small, the region between ALE and PLE protuberant, eye diameters and interdistances: AME 0.05, ALE 0.08, PME 0.03, PLE 0.05, AME-AME 0.14, AME-ALE 0.16, PME-PME 0.28, PME-PLE 0.27. 

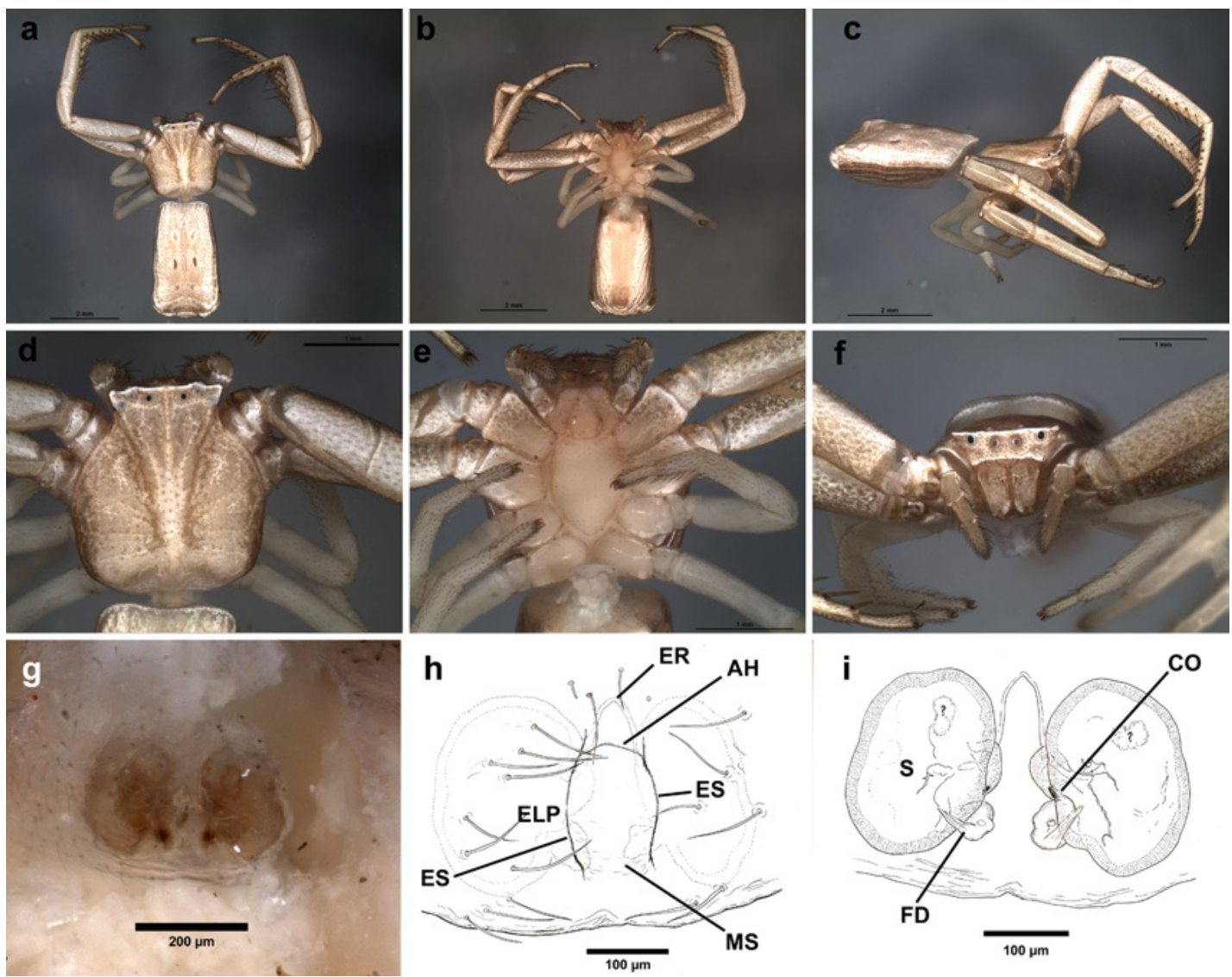

Fig. 14. Uraarachne kapiity n. sp., female paratype (MACN-Ar 39680); a, habitus dorsal, b, same, ventral, c, same lateral, d, carapace, dorsal view, e, same, ventral, f, habitus, anterior view, g-h, epigynum, ventral view, i, internal genitalia, cleared, dorsal view. See abbreviations in the text.

Labium nearly as long as wide (lenght 0.24/width 0.22 ), sternum heart shaped, nearly as long as wide (lenght 0.84 /width 0.72 ). Abdomen nearly rectangular, but thinner than in the female (anterior widht 1.00). Leg spination: I: femur D11-0-0, P1 (very small, subbasal), tibia V2 (the prolateral one very thin)-2-2-2-2-2, metatarsus V2-2-2-2-2, II: femur D1-1-0/1-0, tibia V2-2-22-2, metatarsus V2-2-2-2-2 III: femur D1-1-1, IV: femur D1-1-0-0. Metatarsi III and IV with an apical verticillum of small spines; patellae III and IV also bearing an apical verticillum-like set of three small macrosetae.

Genitalia: palp with relatively elongated and slightly sinuous RTA, with a ventral expansion relatively close to the tip; bulb discoidal, large, with embolus origin at nearly ten o'clock position, dark and thicker and more sinuous than in the other species (Figs. $15 \mathrm{~g}$-j, 23g-h, 25g-h).

Other material examined: PARAGUAY: Itapúa Department: Carmen del Paraná: "donde el Arroyo A ${ }^{\circ}$ Tacuary cruza la ruta 1", (S27²'59.43”, W56 9'7.45”), 17.I.1996. J.A. Kochalka coll., sweeping net at side of the route 1, 1 으 (MNHNP [IBNP-Invert.-JAK-CR-2548]). ARGENTINA: Chaco Province: Presidencia de la Plaza: Los Alisos, S27¹'1.19', W59³7'59.84", 26.XI.2007, grassland, C. Álvarez Bohle coll. 10' (CARTROUNNE 8962), 29.XII.2006, grassland, G. Avalos coll. 1j (CARTROUNNE 8969); Sargento Cabral: Las Garcitas, S26 $34^{\prime} 32^{\prime \prime}$, W59 45 '24', 14.VI.2018, grassland, C. AchitteSchmutzler coll. 19 (CARTROUNNE 8973), Bermejo: La Leonesa, S26 57'40.60", W58 39'03', grassland, 8.XII.2015, G. Avalos coll. 20" (CARTROUNNE 8963), 14.XI.2013, grassland, G. Avalos coll., G-vac, 2j (CARTROUNNE 8970); San Fernando: San Fernando, S27 $30^{\circ} 42.93$ ', W59 4'47.60", 17.X.2013, grassland, G. Avalos col 1j (CARTROUNNE 8971), 28.III.2016 grassland, G. Avalos coll., 2j (CARTROUNNE 8972); Corrientes Province: Mburucuyá: 


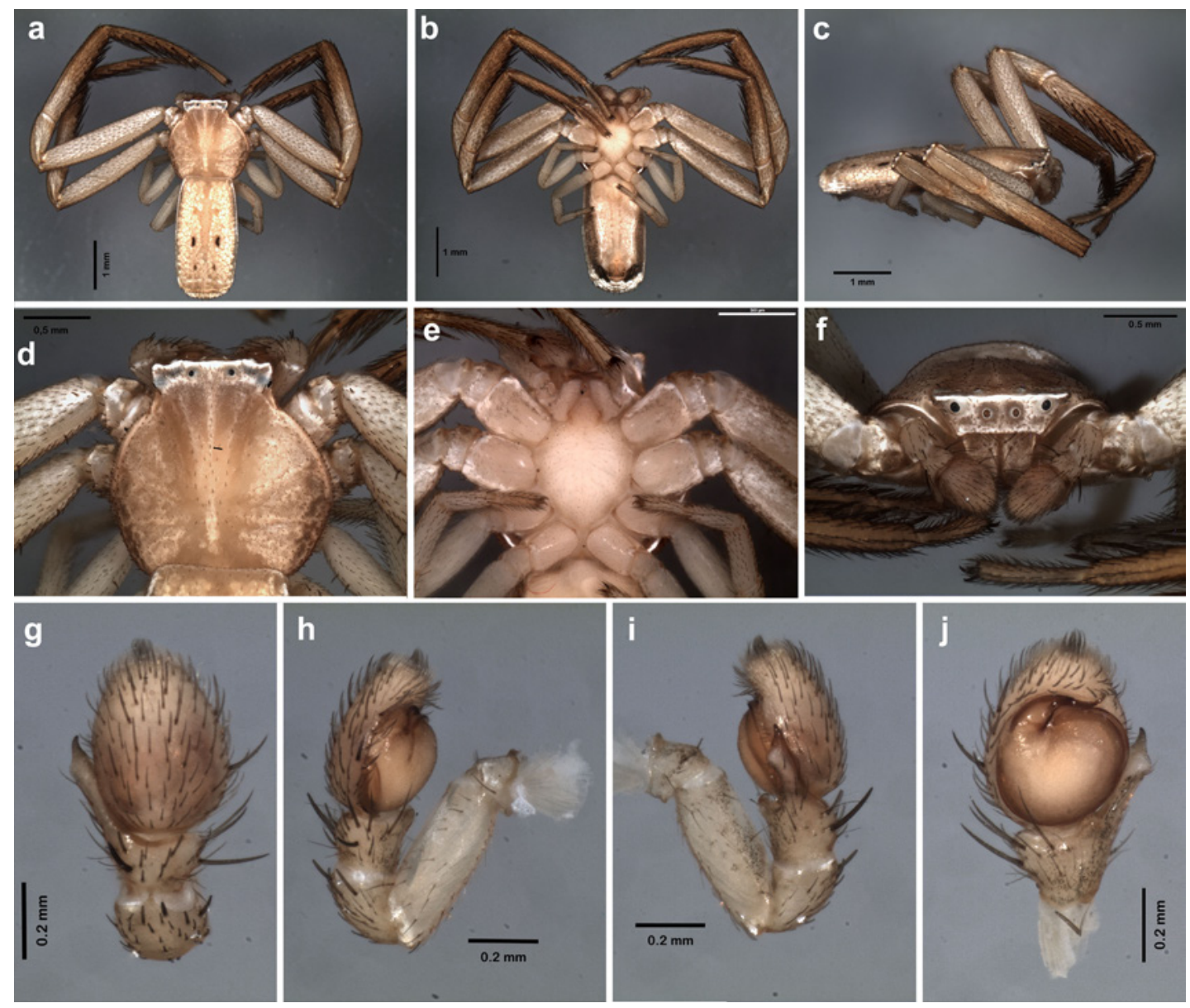

Fig. 15. Uraarachne kapiity n. sp., male holotype; a, habitus dorsal, b, same, ventral, c, same lateral, d, carapace, dorsal view, e, same, ventral, f, same, anterior, g-j, left palp, g dorsal view, h, prolateral, i, retrolateral, $\mathrm{j}$, ventral.

Parque Nacional Mburucuyá, (S28 0 '53.61', W58 4'2.29"), 8.XII.2003, G. Rubio col $1 \mathrm{j}$ (CARTROUNNE 8965), San Miguel: San Nicolás Iberá Park, S28 $10^{\prime}$, W57²6', 20.XI.2012, grassland, G. Avalos coll., 10', 1j (CARTROUNNE 8964), 29 (CARTROUNNE 8968), San Martín: Colonia Pellegrini, S28 32 '41.00", W57 $11^{\prime} 57.00 ”, 2$ 20.XII.2004, G. Rubio coll. 1j (CARTROUNNE 8966), Aguapey (locality not found, probably Aguapey river), XII.1941, M. Birabén coll. 1subadulto (MLP 18550, together specimens of $U$. variegata), same collector, not precise locality, XI.1948, 1 ( Cruz, Paraje Tres Cerros private reserve, S29 $06^{\prime}$, W56 ${ }^{\circ} 55^{\prime}$, 17.IX.2015, grassland, G. Avalos coll. 2j (CARTROUNNE 8967); Entre Ríos Province: Colón: Laguna de las Tortugas, PN El Palmar 8 km E (by air) RN14, S31 $53^{\prime} 8.01^{\prime \prime}$, W58 14 '27.34”" (GPS +-100m), elev. 39 m (GPS), 23.II.2015, M.
Ramírez \& L. Piacentini, hand collecting, 19 (MACN-Ar 40641); same province: no data (probably Concordia, literal label: "Ex Col. Birabén, Number 2 bis"), 1 우 (MLP 18432, together with specimens of $U$. runcinioides).

Etymology. The specific epithet derived from "kapi'ity" (guarani word for grassland), and refers to the habitat this species inhabits.

Distribution. Paraguay and northeastern Argentina (Chaco, Corrientes, and Entre Ríos provinces, Map 5).

Uraarachne plana (Simon, 1895) new combination

(Figs. 2b, 16, 17, 23c-d, 25c-d, 28, map 3)

Runcinia plana Simon, 1895a: 437. Two immature putative syntypes from Paraguay (without specific locality and collector), deposited 

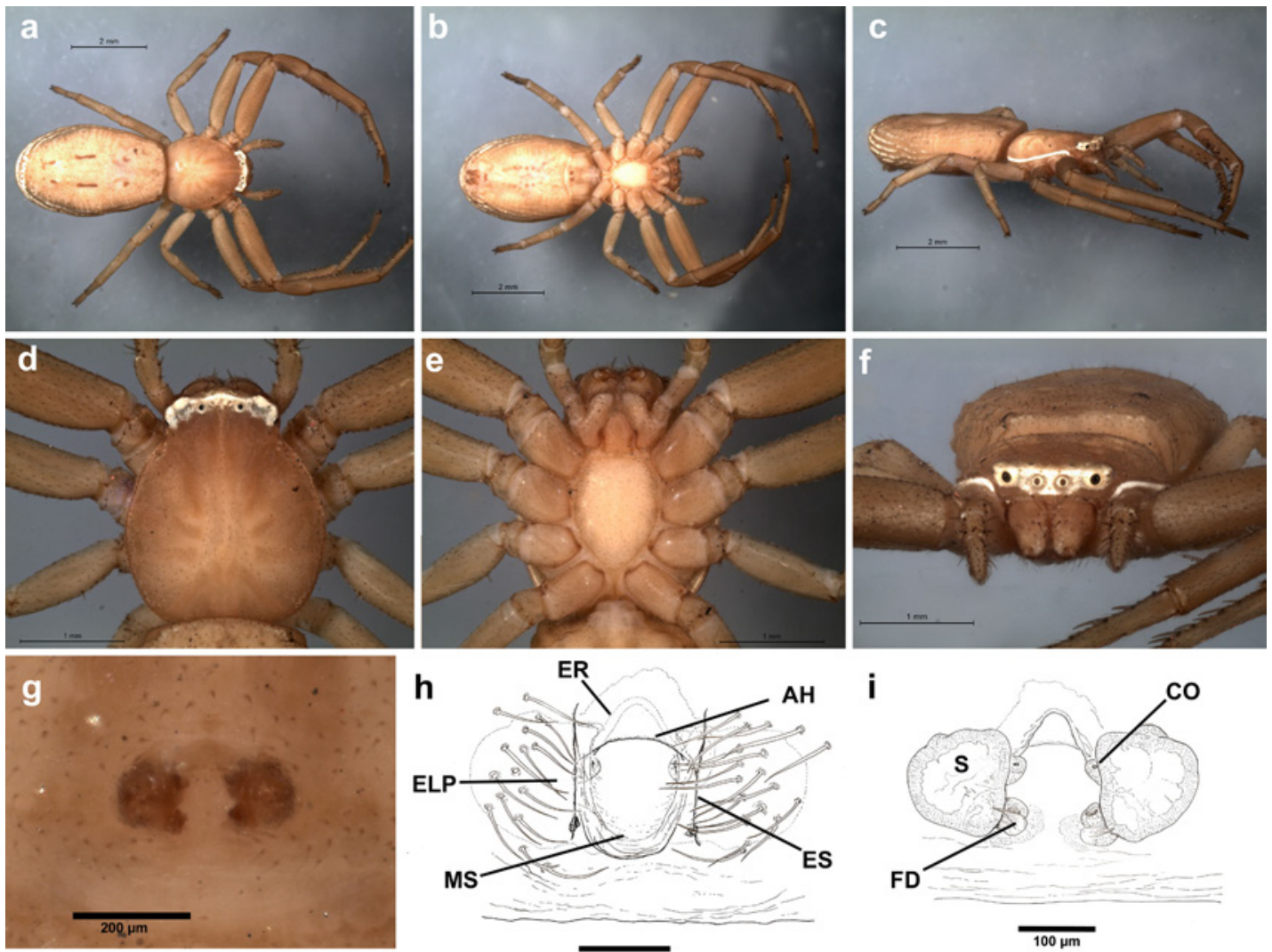

Fig. 16. Uraarachne plana (Simon) n. comb., female (a-g, MACN-Ar 39290, h-i, MACN-Ar 31982); a, habitus dorsal, b, same, ventral, c, same lateral, d, carapace, dorsal view, e, same, ventral, f, habitus, anterior view, g-h, epigynum, ventral view, i, internal genitalia, cleared, dorsal view. See abbreviations in the text.

in MNHN 9324, examined. Roewer 1955: 855; Bonnet 1956: 3886.

Platyarachne argentina Zapata \& Grismado 2016: 205, fig. 4a (misidentification).

Notes: The vial \#9324 of the MNHN contains two immature specimens that correspond to the original description, and are here considered putative syntypes (Fig. $2 \mathrm{~b}$ ). The adult specimens here described are considered conspecific by similar morphology and geographic distribution (the northernmost Argentinian localities for this species are very close to Paraguay).

Diagnosis. Both sexes are recognizable by the less developed ocular protrusions on the ALE and the remarkably flattened and elongated body (Figs. 16, 17). Females of U. plana are similar to those of $U$. toro, n. sp., by having a relatively elongate and caudally rounded abdomen, but differ by the nearly parallel epigynal sutures, by having more separated spermathecae (Figs. $16 \mathrm{~h}, \mathrm{i})$, and by the less developed lateral ocular protrusions.
Description. Female (MACN-Ar 39290, voucher CJG-1805, Fig. 16). Coloration (in ethanol): carapace yellowish, nearly uniform, contrasting transverse white pigment at the eye region and on the lateral carapace margins; endites, labium, and sternum pale yellowish, chelicerae and legs entirely yellowish as the carapace. Abdomen mostly yellowish, with white stripes along the marginal folds, especially on the caudal area, three pairs of elongated, brownish markings (corresponding to the dorsal apodemes); ventrally mostly whitish, with lateral folds converging along the midline, pale yellowish. Measurements. Body length 6.14, prosoma length 2.30 , width 1.94 , opistosoma lenght 4.04 , maximum width 2.48 , legs: length of articles (femur, patella, tibia, metatarsus, tarsus, total): I 2.32, 1.06, 1.78, 1.52, 0.72, 7.40; II 2.00, $0.86,1.54,1.24,0.72,6.36$; III $1.24,0.64,0.76$, $0.52,0.40,3.56$; IV 1.40, 0.60, 0.90, 0.52, 0.40, 3.82. Prosoma very flattened, longer than wide, with short blunt setae, more abundant at the median dorsum. Eyes small, the region between ALE and PLE less protuberant than in the other 

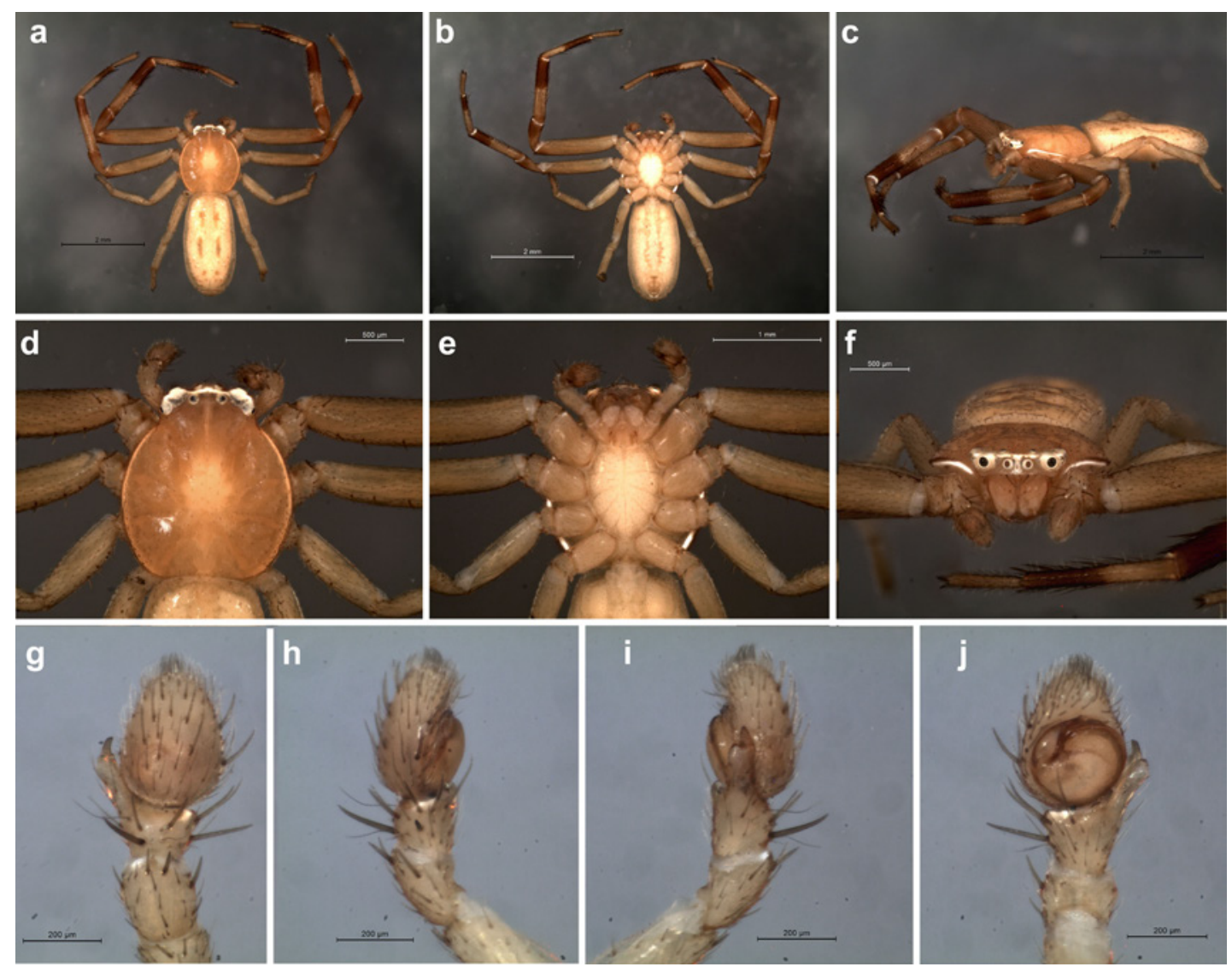

Fig. 17. Uraarachne plana (Simon) n. comb., male (MACN-Ar 33170); a, habitus dorsal, b, same, ventral, c, same lateral, d, carapace, dorsal view, e, same, ventral, f, same, anterior, g-j, left palp, g dorsal view, h, prolateral, i, retrolateral, $\mathrm{j}$, ventral.

species, eye diameters and interdistances: AME 0.06, ALE 0.10, PME 0.04, PLE 0.06, AME-AME 0.16, AME-ALE 0.22, PME-PME 0.32, PMEPLE 0.34. Labium longer than wide (length 0.42 / width 0.30 ), sternum longer than wide (length 1.14/width 0.84). Abdomen flattened, relatively elongated, truncated anteriorly, slightly widened and rounded posteriorly (anterior widht 1.50). Leg spination: I: femur P1 (subbasal, short) tibia VP0-1-1-1-1-1 VR0-1-1-1-1 metatarsus V2-2-22-2; II: tibia V0-2-2-2-2-2, metatarsus VP0-1-11-1-1 VR0-1-1-1-1-1-1-1; femora III and IV with one dorsal small spine (at middle); metatarsus III and IV with an apical verticillum o small spines. Genitalia. Anterior hood relatively wide, epigynal sutures almost parallel, copulatory openings inconspicuous, spermathecal apodemes as dark markings (Fig. 16h), spermathecae separated by nearly their diameters (Fig. 16i).

Male (MACN-Ar 33179, voucher CJG-1804, Fig. 17). Color in ethanol as in female except by the followong: background of prosoma slightly darkened, pale orange; distal half of metatarsi, tibiae and patellae I-II brown. Measurements. Body length 4.20 , prosoma length 1.68 , width 1.50 , opistosoma lenght 2.56 , maximum width 1.30, legs: lenght of articles (femur, patella, tibia, metatarsus, tarsus, total): I 2.02, 0.78, 1.60, 1.34, $0.66,6.40$; II 1.74, 0.72, 1.38, 1.18, 0.66, 5.68; III $0.92,0.48,0.66,0.40,0.30,2.76 ;$ IV $1.10,0.40$, $0.64,0.36,0.30,2.80$. Leg formula I-II-IV-III. Eyes small, the region between ALE and PLE protuberant, eye diameters and interdistances: AME 0.06, ALE 0.10, PME 0.04, PLE 0.06, AME-AME 0.14, AME-ALE 0.12, PME-PME 0.22, PME-PLE 0.22. Labium as long as wide (lenght 0.20 /width 0.20 ), sternum heart shaped, nearly as long as wide (lenght 0.90 /width 0.70 ). Abdomen as in female, but relatively thinner (anterior widht 0.86). Leg spination: I: femur D1-1-1-0-0, P1 (subbasal), tibia V0-2-2-2 (diverse thickness), metatarsus V0-2-2-2-2-2 (diverse 

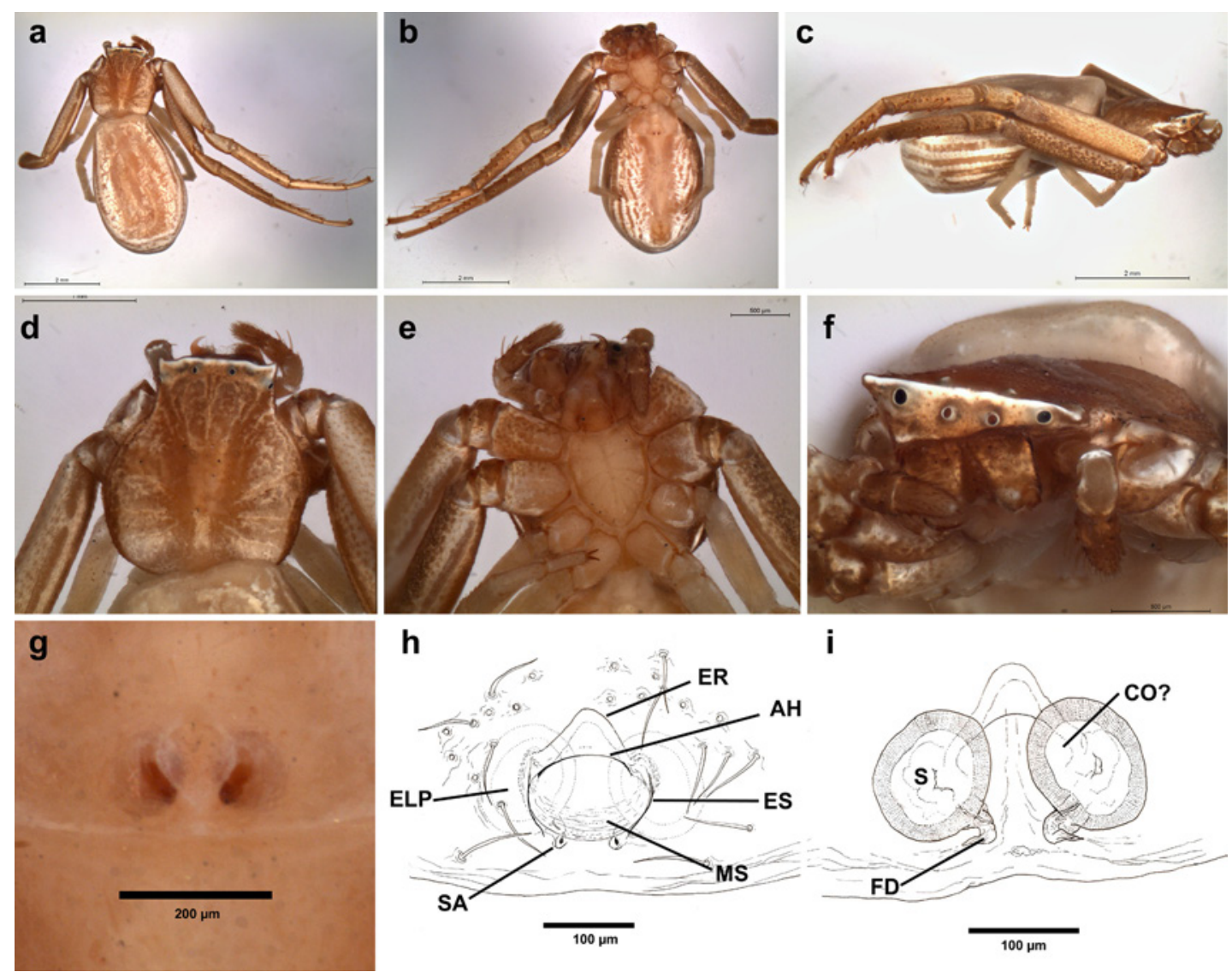

Fig. 18. Uraarachne toro n. sp., female holotype; a, habitus dorsal, b, same, ventral, c, same lateral, d, carapace, dorsal view, e, same, ventral, f, habitus, anterior view, g-h, epigynum, ventral view, i, internal genitalia, cleared, dorsal view. See abbreviations in the text.

thickness), II: femur D1-1-1-0-0, tibia V0-2-2-2 (diverse thickness), metatarsus V0-2-2-2-2-2 (diverse thickness) III: femur D1-1-1-0-0, IV: femur D1-1-1/0-1/0. Metatarsi III and IV with an apical verticillum o small spines.

Genitalia: palp with relatively elongated and slightly sinuous RTA, with a ventral expansion relatively advanced (close to the tip), with rounded outline; bulb discoidal, medium sized, with embolus origin at nearly nine o'clock position (Figs. 17 g-j, 23c-d, 25c-d).

Remarks: several spiders have in vivo a green pigment (Figs. 28 a-b, Zapata \& Grismado 2016: fig. 4a) that no longer persists in preserved specimens.

Other material examined. ARGENTINA: Chaco Province: Presidencia de la Plaza: Parque Nacional Chaco, Laguna Panza de Cabra, Mirador, S26 51'45.2”, W59 37’32.5”, elev. 79 m. 11-13.XI.2007, marsh vegetation, C. Grismado, L. Compagnucci \& G. Galvani coll., sweeping net,
10 (MACN-Ar 40547); Corrientes Province: Capital: Estación Biológica de Corrientes (EBCo), S27 33'07.6”, W5840'48.5', elev. 76 m. 5-10.XI.2007, marsh vegetation, C. Grismado, L. Piacentini, M. Izquierdo, L. Compagnucci \& J. Martínez coll., beating, 10" (MACN-Ar 13129, tissue sample code EMS 4031), Curuzú Cuatiá: marsh at side of Route $14,1.6 \mathrm{~km}$ (by air) SE intersection RN14 and Miriñay river, S29 57'29.484', W 5740'13.799"' (GPS +-50m), elev. 48 m (GPS), 23.II.2015, hand collecting, M. Ramírez \& L. Piacentini (MJR-loc-183b), 1우 (MACN-Ar 40787, voucher CJG-2015); Santa Fe Province: Vera: Toba, (S29'15'55.68', W60¹0’20.28'), X.1967, M. E. Galiano coll. 19 (MACN-Ar 18697); Entre Ríos Province: Federación: Arroyo Mandisoví Grande at Ruta Nac. 14, (S30 $55^{\prime} 0.01^{\prime \prime}$, W58 ${ }^{\circ}$ '59.98”'), 15.VII.1985, M. Ramírez coll. 1j (MACN-Ar 19365), Gualeguay: Gualeguay, (S339'1.18”, W59¹8'37.69"'), 20.VIII.1989, M. Ramírez coll. 1우 (MACN-Ar 18698), 1 우 (MACN- 

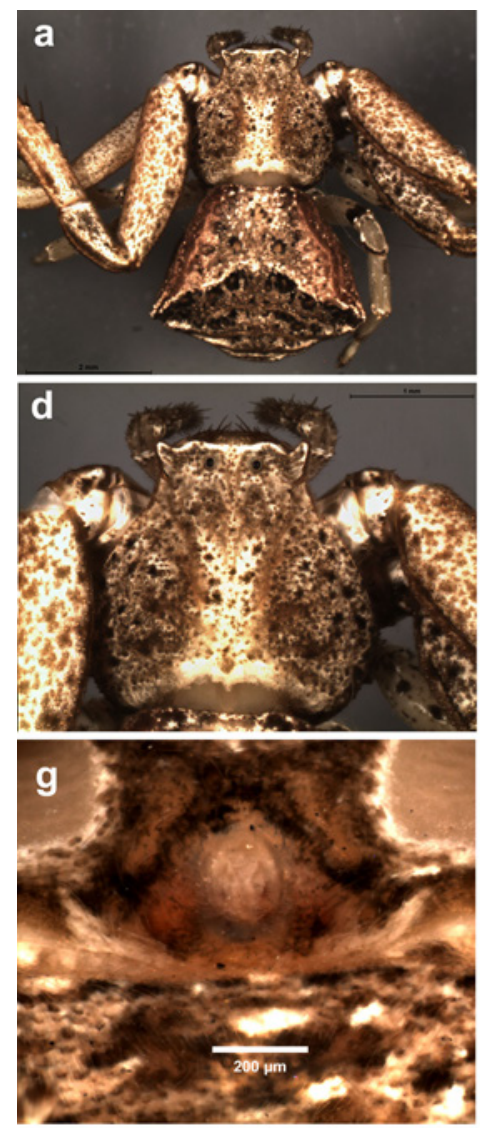
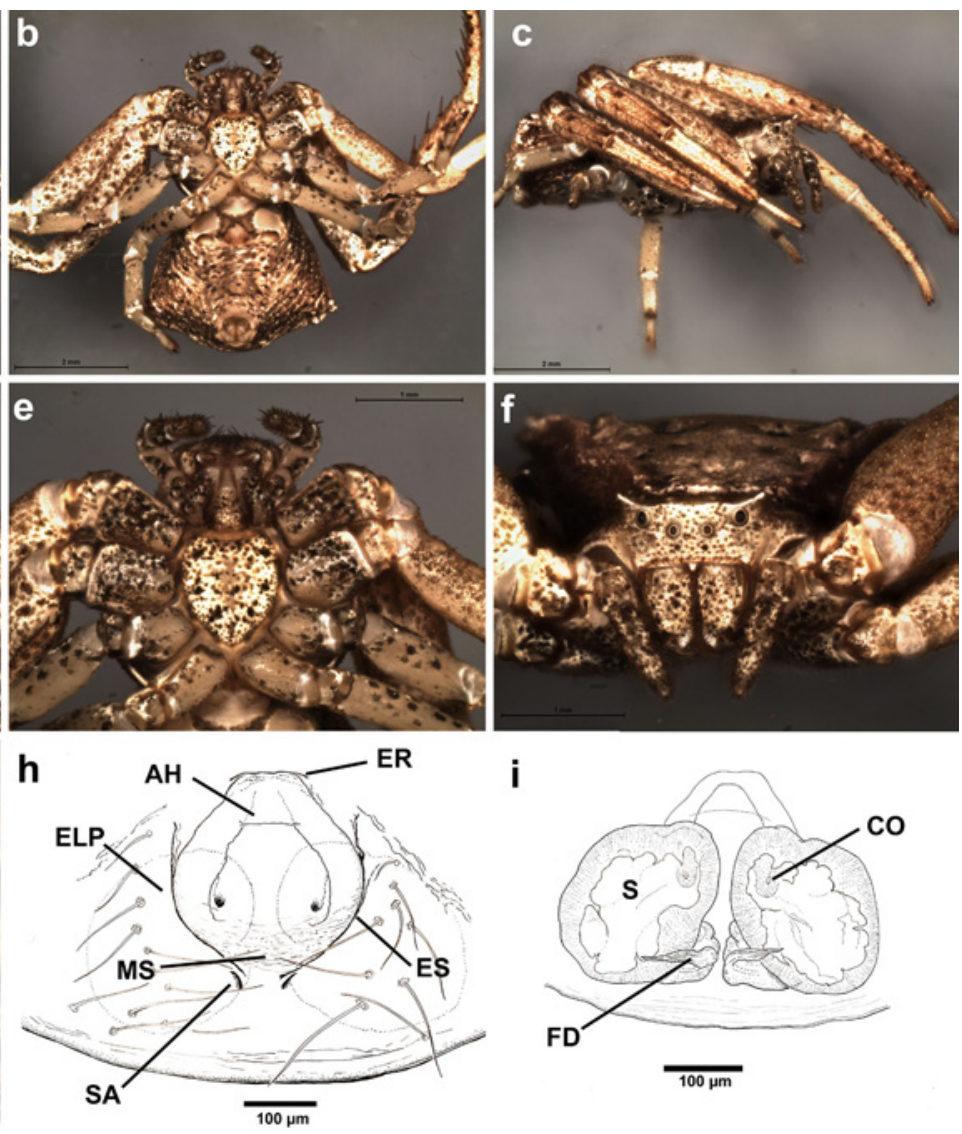

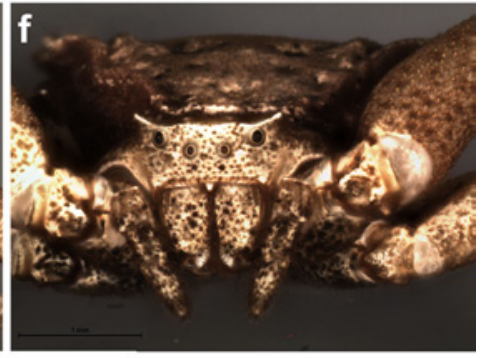

i

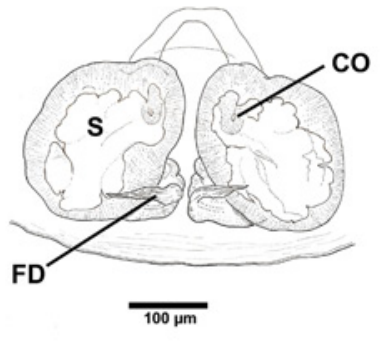

Fig. 19. Uraarachne cornuta (Simon) n. comb., female (a-g, MACN-Ar 19341, h-i, MACN-Ar 32000); a, habitus dorsal, b, same, ventral, c, same lateral, d, carapace, dorsal view, e, same, ventral, f, habitus, anterior view, g-h, epigynum, ventral view, i, internal genitalia, cleared, dorsal view. See abbreviations in the text.

Ar 18699); Uruguay: Río Gualeguaychú, at RN 14, $29 \mathrm{~km}$ (by air) N Gualeguaychú, S32 45 '10.43”, W58 29'12.04" (GPS, +-100m), elev. 6 m (GPS), 20.V.2014, at base of Panicum prionitis, M. Ramírez, L. Piacentini, S. Ceccarelli, I. Magalhaes \& M. Barone coll., hand collecting, $10^{\prime \prime}$ (MACNAr 31477, voucher MJR-1534, photographs MJR 1140-1154), 1ㅇ (MACN-Ar 40646, voucher CLG-1914); Colón: Parque Nacional El Palmar, S31 53'4.59', W58¹4'21.37', elev. 24m (barometer), 7.VIII.2011, marshlands, in Panicum prionitis, M. Ramírez and MACN-Ar team coll. 10' (MACN-Ar 33170, voucher CJG-1804), 19, 2j (MACN-Ar 33171), 19 (MACN-Ar 33167, tissue sample CJG-3327); S31 53'5.42', W58 14'21.48”, (GPS, +-10m), elev. 25m (barometer), same locality and collectors, grassland near marshlands: on grass tillers, 1, $1 \mathrm{j}$ (MACN-Ar 33204), Arroyo El Palmar, S31 53 '35.08', W58 $14^{\prime} 18.48^{\prime \prime}$ (GPS, $+-150 \mathrm{~m}$ ), elev.10m (GPS), palm groves over stone and grassland, gallery forest, 1 ( (MACN-Ar
32822), 19 (MACN-Ar 32879); Buenos Aires Province: Paraná de Las Palmas, (S34 17’0.55", W58 35'22.90"'), 2.IV.1964, M. E. Galiano coll. 10" (MACN-Ar 18700); Avellaneda: Sarandí: Reserva Natural de Avellaneda "La Saladita", S 34 40' 20.02" W 58 20' 25.71" (Google Earth), (CJGLoc-37), in plants around the pond, 21.X.2019, C. Grismado col, 1 juvenile (MACN-Ar 40876); General Lavalle: Parque Nacional Campos del Tuyú, $1.12 \mathrm{Km}$ NNW seccional Tapera Moya, S36 20'54.7', W 56 51'44”, elev. $7 \mathrm{~m}, 24-26$. III.2012, flooded grassland, L. Piacentini, G. Rubio \& M. Izquierdo coll. 19 (MACN-Ar 31982, voucher CJG-2753); Ciudad Autónoma de Buenos Aires: Reserva Ecológica Costanera Sur, camino de los sauces: mirador al Canal Sur, S34 ${ }^{\circ} 37^{\prime} 1.75^{\prime \prime}$, W58 $20^{\prime} 50.28^{\prime \prime}, 24 . X .2011$, in Cortaderia selloa$n a$, L. Zapata, G. Rubio, M. Izquierdo, M. Guala \& C. Grismado coll. 19 (MACN-Ar 39290, voucher CJG-1805), same date and collectors, Tessaria integrifolia forest, in patch of Panicum maxi- 


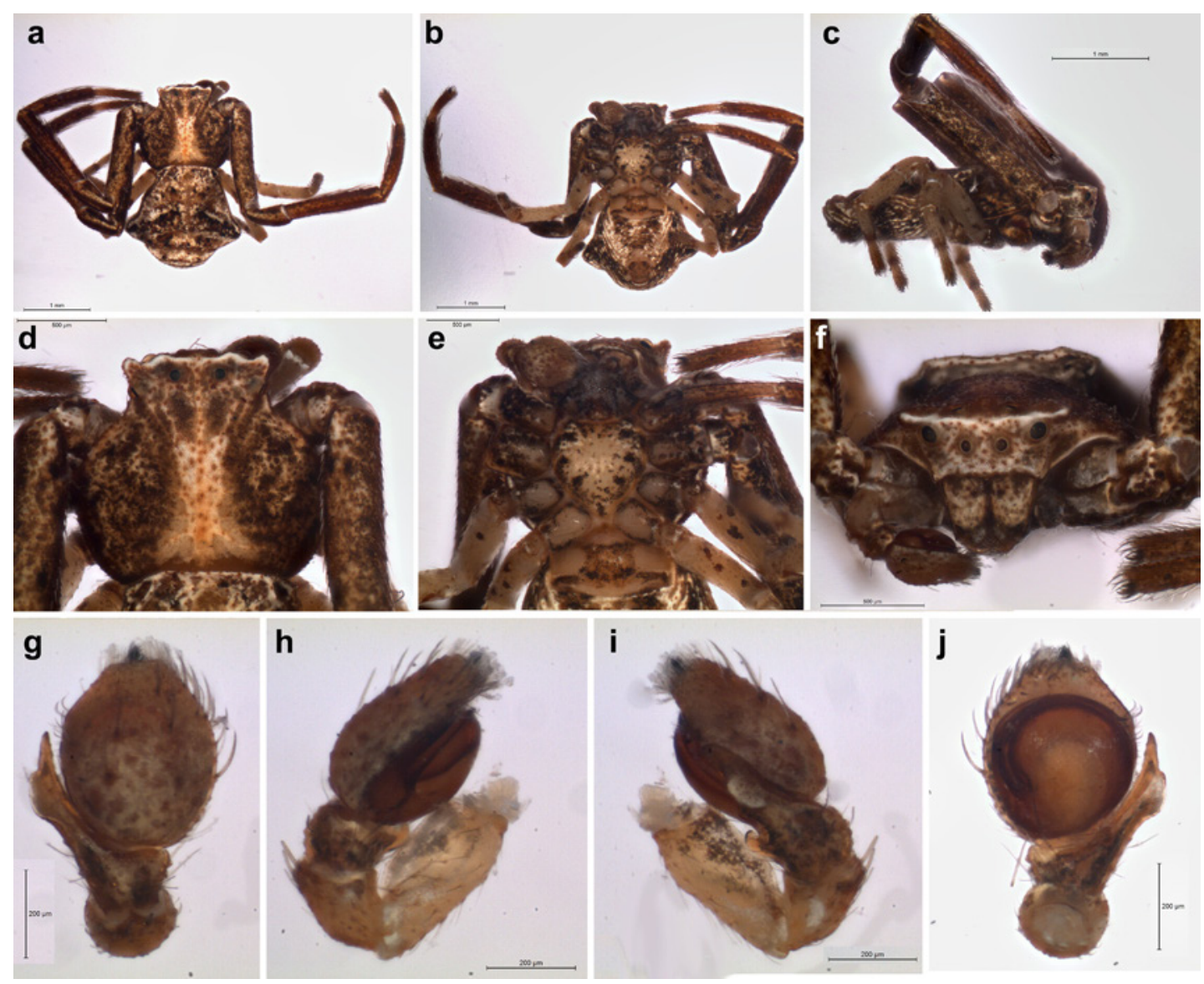

Fig. 20. Uraarachne cornuta (Simon) n. comb., male (MACN-Ar 33575); a, habitus dorsal, b, same, ventral, c, same lateral, d, carapace, dorsal view, e, same, ventral, f, same, anterior, g-j, left palp, g dorsal view, h, prolateral, $\mathrm{i}$, retrolateral, $\mathrm{j}$, ventral.

mum, S34'36'17.8', W58²0'57.2', 19 (MACNAr 39281).

Distribution. Paraguay and Eastern Argentina (Chaco, Corrientes, Santa Fe, Entre Ríos and northern Buenos Aires, Map 3).

Natural History. The data available suggest that this species seems to prefer "totoras" (Typha sp.), "pampas grasses" (Cortaderia selloana) and other riparian plants with stems or leaves elongated, typical of the wetlands, and other areas neighboring watersourses.

\section{Uraarachne toro, new species} (Fig. 18, map 5)

Type material. Female holotype from Argentina: Salta Province: Río "Carapay" (actually Caraparí or Itiyuro) (S22 27'24.3”, W6328'51.0”), 30.III.1949, M. Kormilev coll. Deposited in MACN-Ar 2754.
Diagnosis. Females of $U$. toro are similar to those of $U$. plana in having a relatively elongated and caudally rounded abdomen, but differ by the more acute protrusions on the ALE (Figs. 18a, d, f), by the curved epigynal sutures and by the spermathecae small and closer to each other (Fig. 18i). Description. Female holotype (MACN-Ar 2754, voucher CJG-1741, Fig. 18). Coloration (in ethanol): carapace light brown, with a longitudinal wide, lighter band at middle with thinner white stripes forwardly to the eye region; lateral lighter areas constituted by many thin lines radiating to the carapace margin; eye region with a narrow transverse white band. Endites, labium, and sternum light brown, chelicerae brown with light transversal median band; legs light brown, with longitudinal whitish areas on I-II. Abdomen mostly pale brown, suffused with white pigment mostly at sides and along the marginal folds, especially on the caudal area; dorsal apodemes 

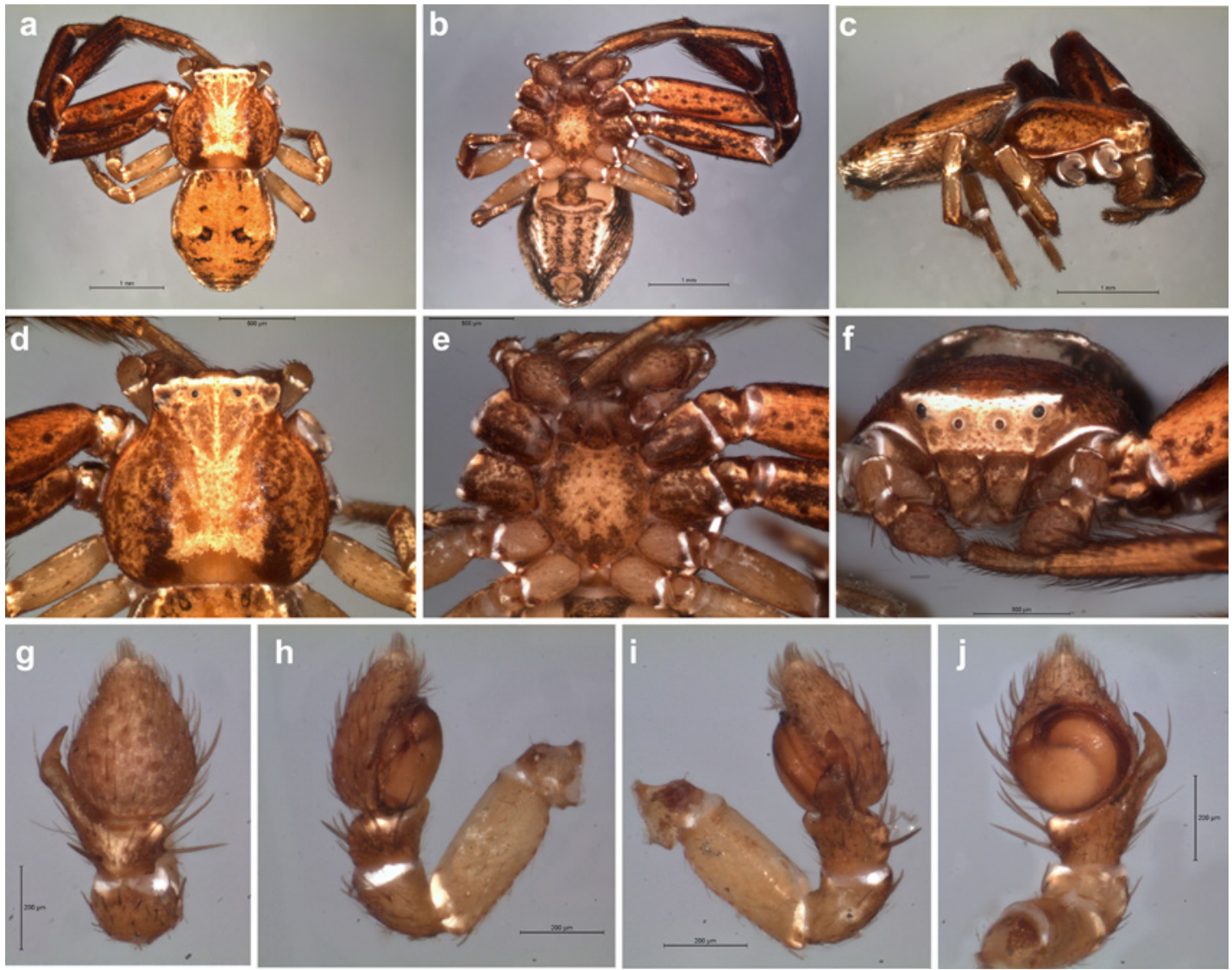

Fig. 21. Uraarachne panthera n. sp., male holotype; a, habitus dorsal, b, same, ventral, c, same lateral, d, carapace, dorsal view, e, same, ventral, f, same, anterior, g-j, left palp, g dorsal view, h, prolateral, i, retrolateral, j, ventral.

inconspicuous; lateral folds on mostly white background extending ventrally and leaving a narrow median pale brown band. Measurements. Body length 5.65, prosoma length 2.02, width 1.80 , opistosoma lenght 3.80 , maximum width 2.44, legs: length of articles (femur, patella, tibia, metatarsus, tarsus, total): I 2.38, 0.98, 1.90, 1.56, $0.60,7.42$; II 2.30, 0.96, 1.76, metatarsi and tarsi missing); III 1.00, 0.46, 0.66, 0.42, 0.34, 2.88; IV $1.24,0.50,0.78,0.54,0.36,3.42$. Prosoma (crushed) longer than wide, flattened, with short blunt setae. Eyes small, the region between ALE and PLE notably protuberant, as acute horns, eye diameters and interdistances: AME 0.04, ALE 0.08, PME 0.04, PLE 0.05, AME-AME 0.16, AME-ALE 0.18, PME-PME 0.30, PME-PLE 0.33 . Labium almost as long as wide (length $0.30 /$ width 0.24 ), sternum longer than wide (length 0.94/width 0.66). Abdomen moderately flattened, relatively elongated, truncated anteriorly, slightly widened and rounded posteriorly (anterior widht 1.40). Leg spination: I: tibia V0-2-2-
2-2 metatarsus V1-2-2-2-2-2; II: tibia V0-2-1-2-2, metatarsus missing; metatarsus III and IV with an apical verticillum o small spines.

Genitalia. Anterior hood relatively wide, almost triangular, epigynal sutures strongly curved, spermathecal apodemes marked with small orifices (Fig. 18h), spermathecae small, spherical, separated by nearly their radius (Fig. 18i).

Male unknown.

Etymology. The specific epithet is a patronymic in honor of the famous singer and song-writer Daniel Toro, born in Salta in 1941, and author of many of the most beautiful and popular folkloric songs of Argentina.

Other material examined. ARGENTINA: Santiago del Estero Province: Alberdi: Campo Gallo, (S26 $\left.35^{\prime} 0.52^{\prime \prime}, \mathrm{W} 62^{\circ} 50^{\prime} 42.86^{\prime \prime}\right)$, III.1943, a. Prosen coll. 2subadulto (MLP 18489).

Distribution. Known from only two localities in Salta and Santiago del Estero, northwestern Argentina (Map 5). 

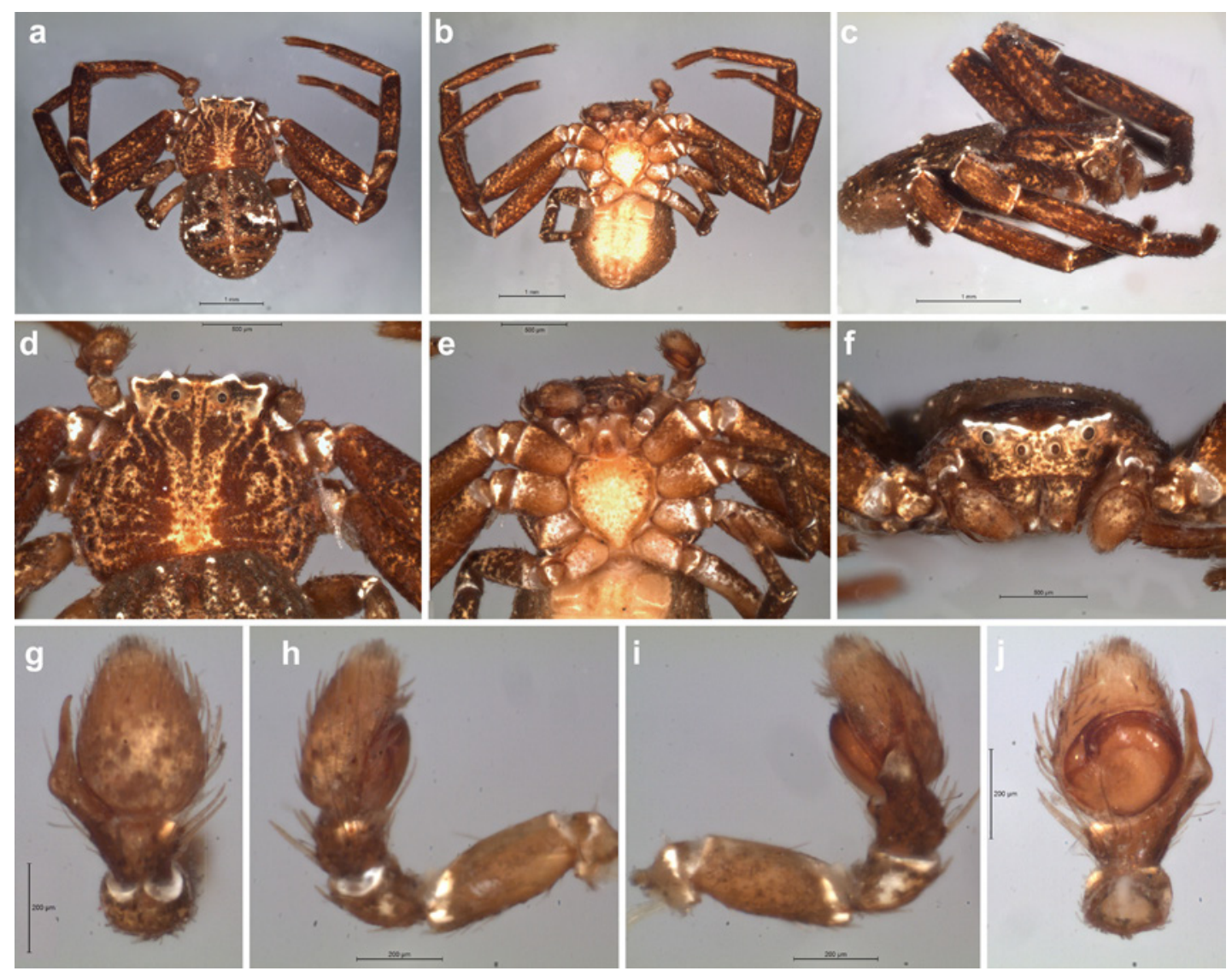

Fig. 22. Uraarachne ceratophrys n. sp., male holotype; a, habitus dorsal, b, same, ventral, c, same lateral, d, carapace, dorsal view, e, same, ventral, f, same, anterior, g-j, left palp, g dorsal view, h, prolateral, i, retrolateral, j, ventral.

Uraarachne cornuta (Simon, 1886) new combination

(Figs. 1i-1, 5, 19, 20, 24a,d, 26a,d, 29, Map 4)

Plancinus cornutus Simon, 1886: 175. Female holotype from "Banda Oriental del Uruguay" (currently Uruguay), presumably collected by Karl Berg, deposited in MNHN 5435, examined. Roewer 1955: 852; Bonnet 1956: 3699; Lehtinen 2004, 178.

Misumenoides sp. indet. Zapata \& Grismado 2016: 205, fig. 4b (misidentification).

Notes. The MNHN holds two vials with Simon's labels, identified as "Plancinus cornutus": the number 5435 says "Banda Oriental del Uruguay"; it contains one female, one immature, and one subadult female of a different species. We assume that the adult female is the holotype, by correspondence with the type locality and the published description (Figs. 1i-l).

The other vial (9032), is only labeled as
"Paraguay" and contains one adult female and one juvenile, conspecific with the holotype.

Diagnosis. This species is recognizable by its short abdomen, wider than long or as wide as long, nearly pentagonal. The epigynum has the median septum very wide and laterally expanded, with very conspicuous orifices corresponding to the spermathecal apodemes; the male palp has the RTA with a lateral membranous area, very large and discoidal bulb, and the longest embolus of all species, with its origin at nearly seven o'clock position (Figs. 20 g-j, 24a, d, 26a, d).

Description. Female (MACN-Ar 19341, voucher CJG-1806, Fig. 19). Coloration (in ethanol): carapace light brown, with a longitudinal wide, light stripe at middle, all surface profusely mottled with dark brown; endites, labium, sternum, and chelicerae with same background as the carapace, and also covered with many dark brown dots; legs slightly lighter, but also with small dark dots, which more abundant on ventral suface of coxae I-II and larger and more spaced on 

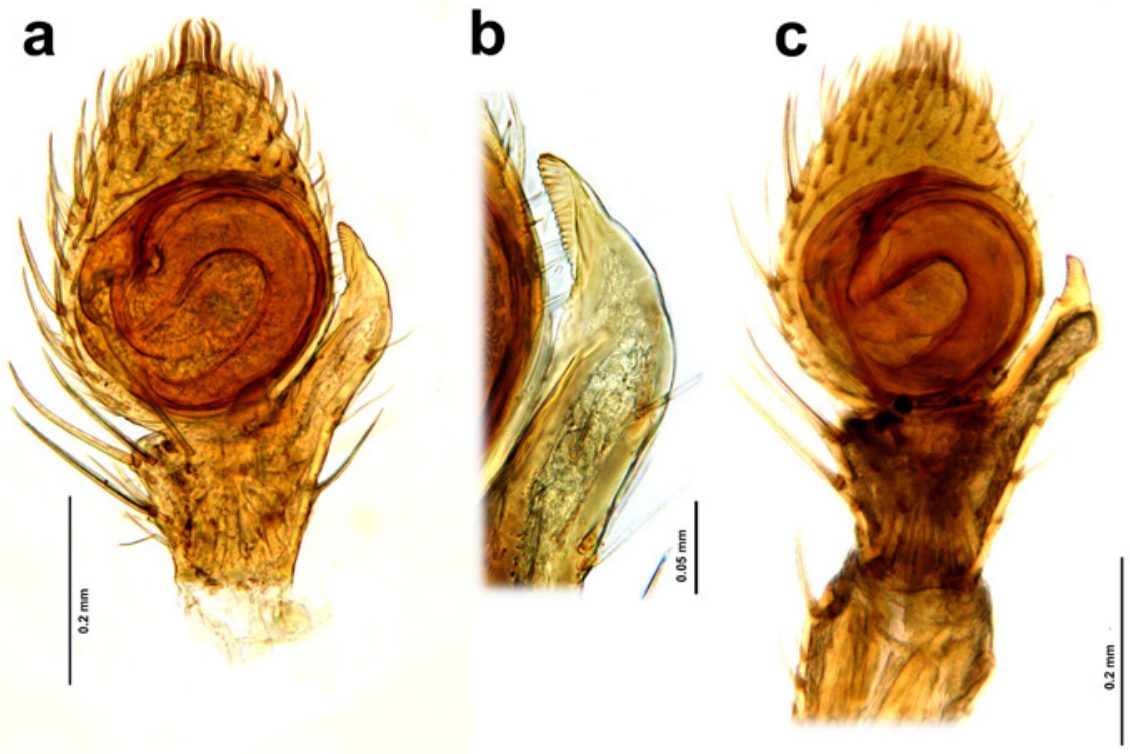

d
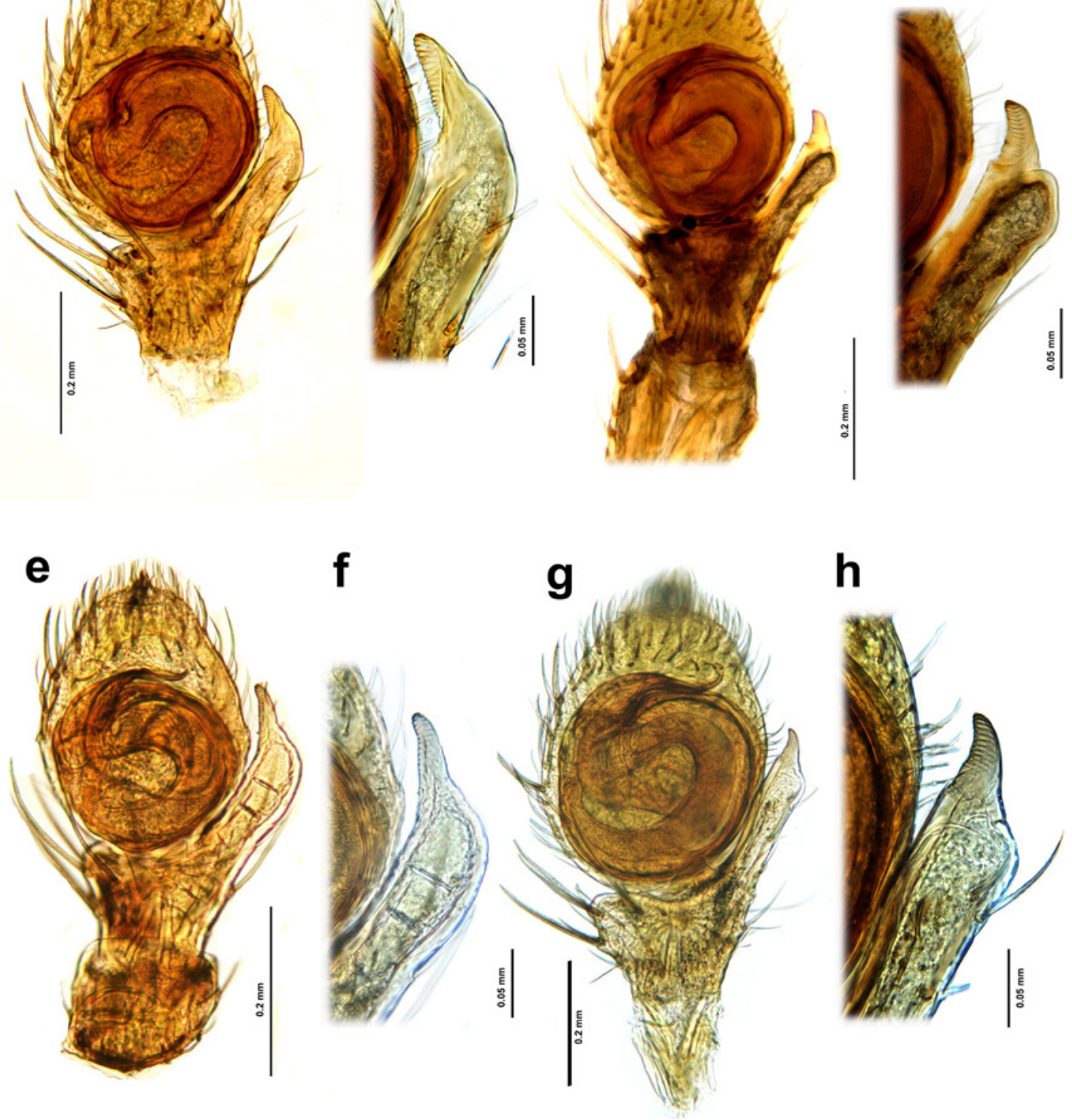

Fig. 23. Uraarachne spp. from Argentina, male palps, cleared, ventral view. a-b, U. runcinioides (Simon), c-d, $U$. plana (Simon), e-f, U. variegata (Mello-Leitão), g-h, U. kapiity n.sp. a, c, e, g, entire palps, b, d, f, h, details of RTA.

legs III-IV; patellae and distal third of tibiae I-II with denser dark pigment. Abdomen mostly light brown, with complex pattern of dark spots similar as the prosoma, but conforming ocellar markings, paired on the anterior dorsum (corresponding presumably to the dorsal apodemes) and alligned on the posterior half, running to the five vertices of the nearly pentagonal abdomen. Light brown marginal folds at sides; ventrally mostly ligh brown, with lateral folds converging along the midline, and mostly covered with small dark spots, except the pedicel region and the booklung covers. Measurements. Body length 5.20, prosoma length 2.40 , width 2.32 , opistosoma lenght 2.92 , maximum width 1.78 , legs: length of articles (femur, patella, tibia, metatarsus, tarsus, total): I 

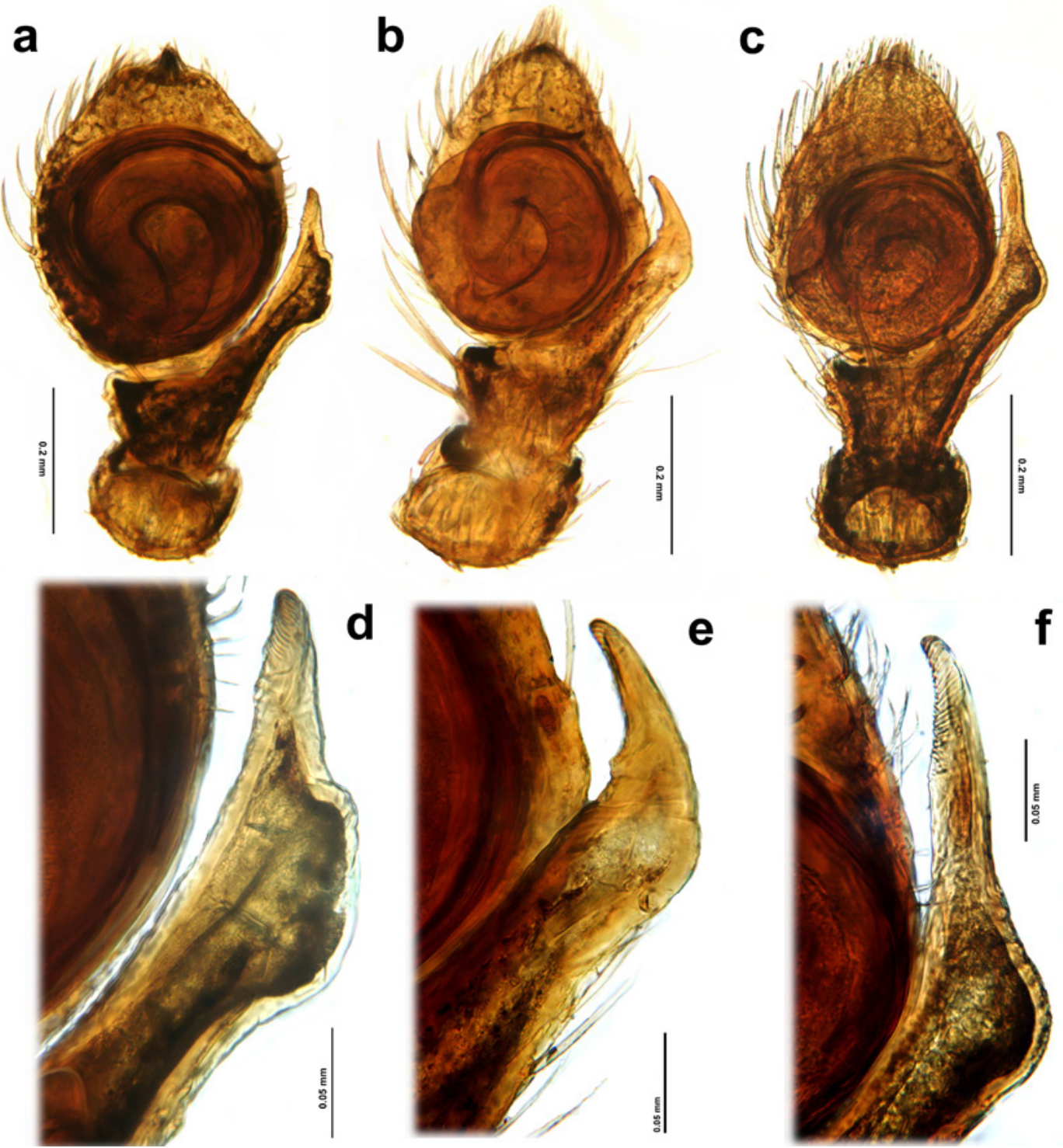

Fig. 24. Uraarachne spp. from Argentina, male palps, ventral view. a, d, U. cornuta (Simon), b, e, U. panthera n.sp., c-f, U. ceratophrys n. sp. a, b, c, entire palps, d, e, f, details of RTA.

$3.12,1.42,2.40,2.04,0.94,9.92 ;$ II $2.84,1.26,2.22$, $1.86,0.90,9.08$; III $1.24,0.62,0.90,0.58,0.50$, 3.84 ; IV 1.50, 0.46, 0.96, 0.64, 0.52, 4.08. Prosoma relatively flattened, longer than wide, with short blunt setae. Eyes small, the region between ALE and PLE very protuberant, resembling small horns; eye diameters and interdistances: AME 0.07, ALE 0.08, PME 0.06, PLE 0.08, AME-AME 0.20, AME-ALE 0.20, PME-PME 0.30, PMEPLE 0.34. Labium longer than wide (length 0.46 / width 0.36 ), sternum longer than wide (length 2.00/width 0.94). Abdomen nearly pentagonal, truncated anteriorly, widened posteriorly (anterior widht 1.46). Leg spination: I: tibia V0-2-2-2 metatarsus V0-2-2-2-2-2-2; II: tibia V1-2-2-2, metatarsus V1 (small)-2-2-2-2-2; metatarsi III and IV with an apical verticillum o small spines. Genitalia. Anterior hood relatively narrow, epigynal sutures curved, reddish; median septum oval, laterally expanded, copulatory openings inconspicuous; posterior holes corresponding to the spermathecal apodemes (Figs. 5g, 19h), spermathecae relatively large, globose, very close each to other (Fig. 5h, 19i). 

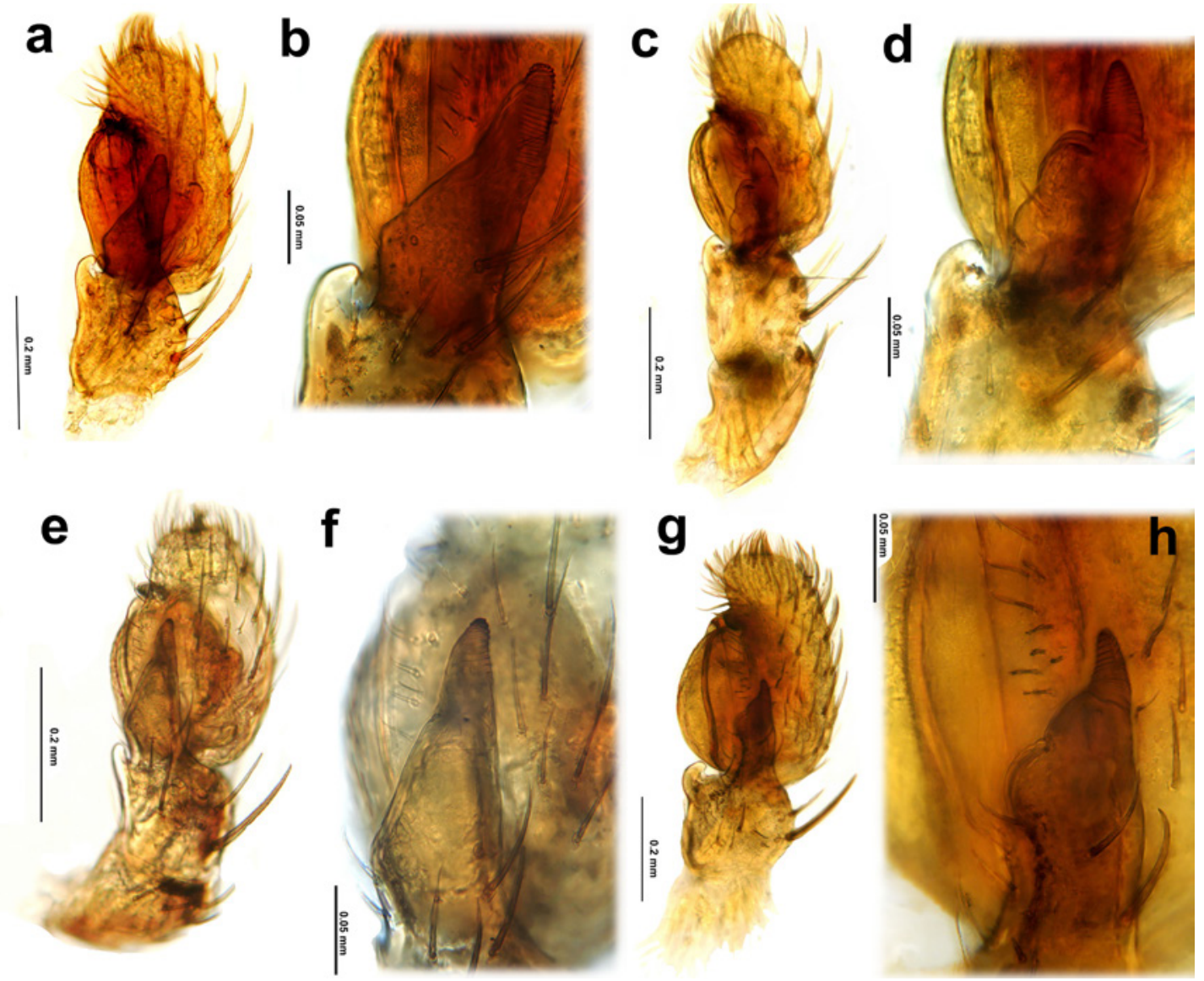

Fig. 25. Uraarachne spp. from Argentina, male palps, cleared, retrolateral view. a-b, U. runcinioides (Simon), c-d, U. plana (Simon), e-f, U. variegata (Mello-Leitão), g-h,U. kapiity n.sp. a, c, e, g, entire palps, b, d, f, h, details of RTA.

Male (MACN-Ar 33575, voucher CJG-174, Fig. 20 ). Color in ethanol as in female except by the following: most surface of metatarsi I-II and distal part of tibiae I-II darkened, legs III and IV with only sparse spots; sternum with less spots in the central part, mainly concentrated on the lateral margins. Measurements: body length 2.80 , prosoma length 1.28 , width 1.40 , opistosoma lenght 1.52 , maximum width 1.78 , legs: lenght of articles (femur, patella, tibia, metatarsus, tarsus, total): I $1.92,0.70,1.52,1.40,0.70,6.24$ II $1.86,0.68,1.44,1.30,0.68,5.96$; III $0.76,0.40$, $0.52,0.44,0.34,2.46$; IV $0.90,0.36,0.54,0.44$, $0.34,2.58$. Leg formula I-II-IV-III. Eyes as in the female; diameters and interdistances: AME 0.04, ALE 0.10, PME 0.04, PLE 0.06, AME-AME 0.12, AME-ALE 0.10, PME-PME 0.20, PMEPLE 0.22. Labium as long as wide (lenght 0.20 / width 0.18), sternum heart shaped, nearly as long as wide (lenght 0.64 /width 0.62). Abdomen nearly pentagonal, truncated anteriorly, widened posteriorly (anterior widht 0.96) with lateral extensions more protuberant than in the female. Leg spination: I: tibia V0-2-2-2 (very thin), metatarsus V0-2-2-2-2 (very thin), II: tibia V2-2-2-2 (very thin), metatarsus V0-2-2-2-2 (very thin) III: femur D0-2-2-2-2-2-2 (small, sightly displaced pairs), IV: femur D1-1-0-1 D0-2-2-2-2-2-2-2 (small, sightly displaced pairs). Metatarsi III and IV with an apical verticillum of small spines.

Genitalia: palp with relatively elongated and slightly sinuous RTA, with a lateral membranous area at the level of the ventral expansion; bulb discoidal, relatively large, embolus long, arising at nearly seven o'clock position (Figs. 20 g-j, 24a, $d, 26 a, d)$.

Other material examined. ARGENTINA: Salta Province: La Viña: Talapampa (S 2532'33.70", W65 33'52.27'), 20.XII.1994, C. Grismado coll. 19 (MACN-Ar 19339); Formosa Province: Pilcomayo: Puerto Pilcomayo (S2522'21.48”, W57'39'5.21'), 
a
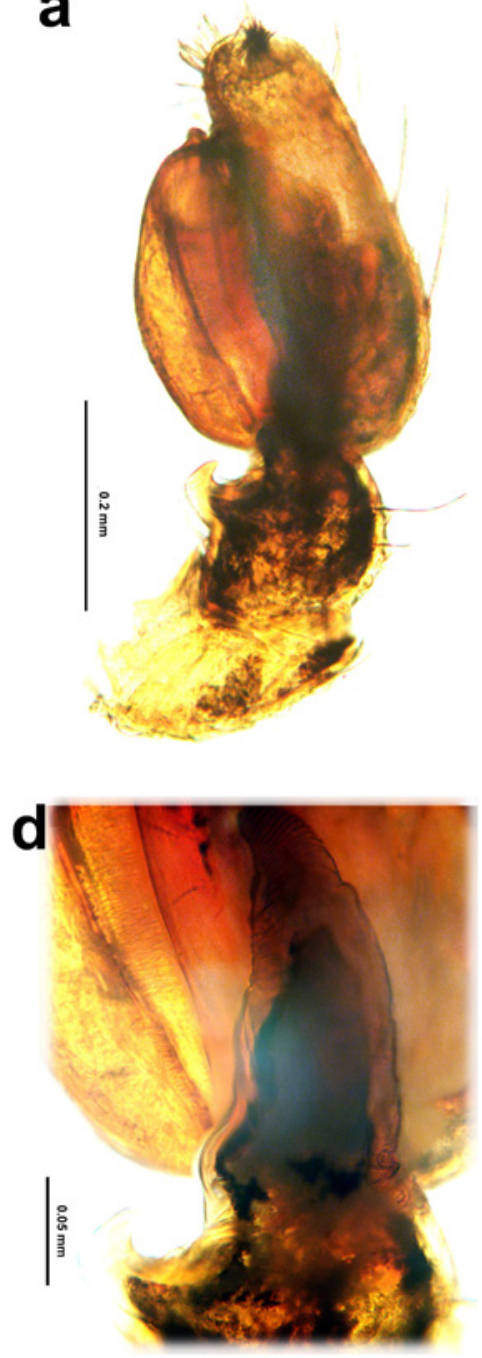

b
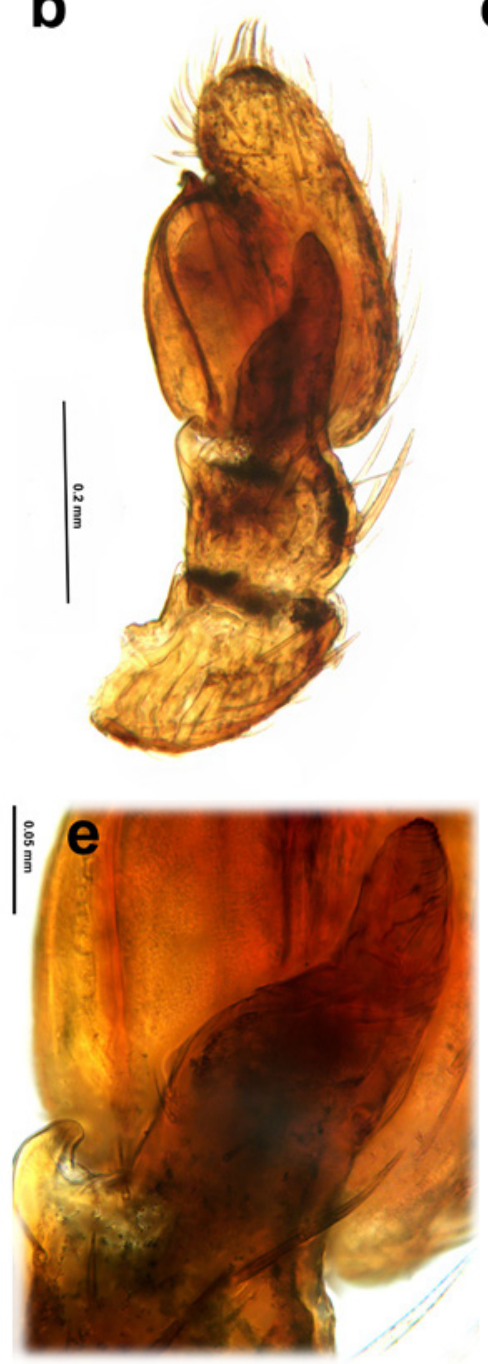

C
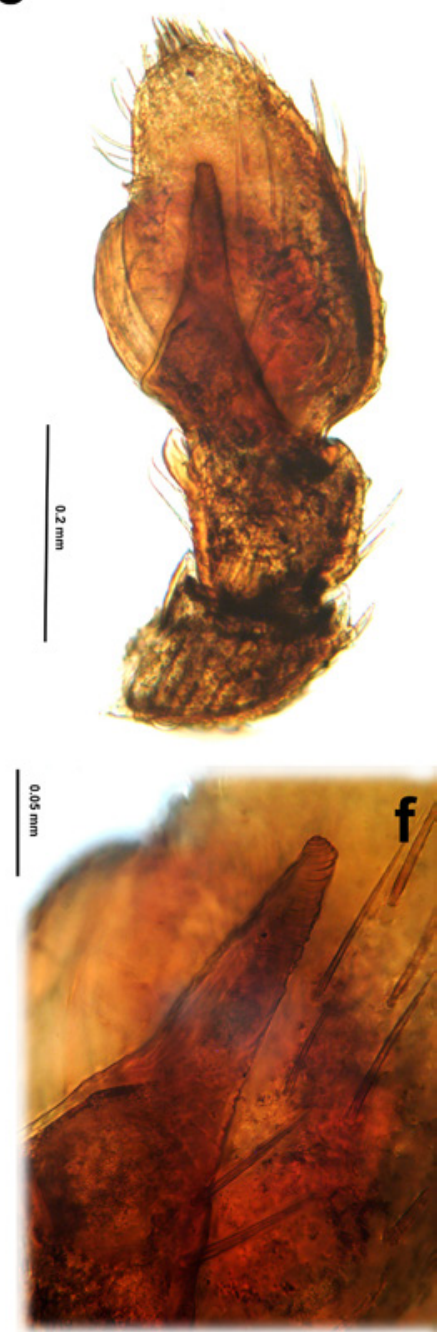

Fig. 26. Uraarachne spp. from Argentina, male palps, cleared, retrolateral view. a, d, U. cornuta (Simon), b, e, U. panthera n.sp., c-f, U. ceratophrys n. sp. a, b, c, entire palps, d, e, f, details of RTA.

XI.1990, M. Ramírez coll. 1ㅇ (MACN-Ar 19334); Chaco Province: Presidencia de La Plaza: Parque Nacional Chaco, S26 $47^{\prime} 56^{\prime \prime}$, W59 37'21', 7.XI.2016, forest, G. Avalos coll. 10' (CARTROUNNE 8974); Corrientes Province: Esquina: Esquina, (S30¹'6.54', W59 31'53.07'), 16.VIII.1999, L. Compagnucci coll. 1j (MACN-Ar 19338), San Miguel: San Nicolás, Parque Iberá, S28 ${ }^{\circ} 10^{\prime}$, W57 $26^{\circ}$, 20.XI.2012, forest, G. Avalos coll. 10", 19, 1subadulto (CARTROUNNE 8975);

Santa Fe Province: Vera: $20 \mathrm{~km}$ W Las Gamas, (S29²5'35.57', W60²1'9.94”), 27-30.X.1994, M. Ramírez \& J. Faivovich coll. 19 (MACN-Ar 19341); Buenos Aires Province: La Plata: Isla
Martín García, (S34¹0'56.94', W58¹4'56.79'), 15-22.II.1933, Daguerre \& Pérez-Moreau coll. 19 (MACN-Ar 19342); Tigre: Tigre, (S3425'30.31', W58 $\left.34^{\prime} 46.77^{\prime \prime}\right)$, F.C.G.M., 5.X.1937, J. Viana coll. 2j(MACN-Ar 253); San Isidro: Acassusso, Reserva Municipal Refugio Natural Educativo Ribera Norte, Sauzal, S3428'2.24", W58 29'37.14" (GPS, +-7m), elev. 7 m, 28.XI.2014, R. Rodríguez Landó \& L. Rodriguez Demarco coll., beating foliage, $10^{\prime \prime}, 19$ (MACN-Ar 33575, vouchers CJG1743 and 1744), same locality, hand collecting, 9.VI.2014, C. Grismado, R. Rodríguez Landó \& L. Peralta coll., 19 (MACN-Ar 32000, voucher CJG1751); Avellaneda: Sarandí: Reserva Natural 

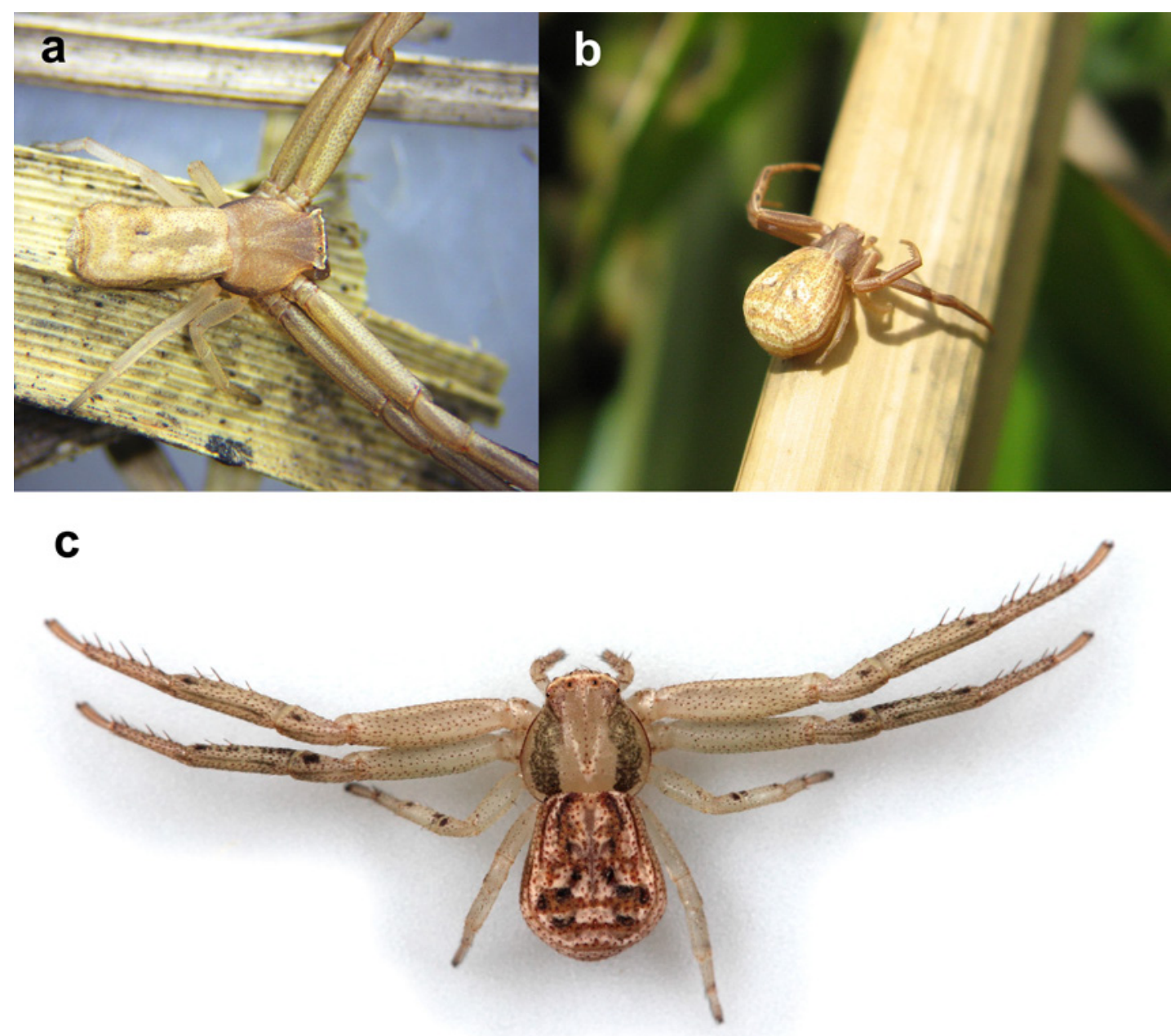

Fig. 27. Uraarachne spp., living specimens. a, U. kapiity n. sp., female from Las Garcitas (Chaco); b, c, U. variegata (Mello-Leitão) females from Reserva Ecológica Costanera Sur (Ciudad de Buenos Aires). Photo credits; a, Cecilia Achitte-Schmutzler, b, Lorena V. Zapata, c, Martín J. Ramírez.

de Avellaneda "La Saladita", S3440'20.02" W58²0'25.71" (Google Earth), (CJG-Loc-37), in plants around the pond, 21.X.2019, C. Grismado coll., 1 subadult male (MACN-Ar 41740), 1 subadult female (MACN-Ar 41741); Quilmes: Quilmes, (S3443'14.28', W58¹5'16.58') no date, J. Viana coll., 2\%, 1j (MACN-Ar 19408); "Buenos Aires", no precise locality, Ferraris coll., 2 (MLP 18540); Ciudad Autónoma de Buenos Aires: Reserva Ecológica Costanera Sur: (S34³6'29.18', W58 21'3.32'), 29.IX.2014, M. Izquierdo \& L. Piacentini coll., foliage beating, 10", 1j (MACN-Ar 36272), sector in recovery (ex COVIMET) between sauzal and Camino de los Plumerillos, (S34³6'48.10”, W58 21'6.77’'),
18.I.2016, A. Porta \& L. Zapata coll., foliage beating, 10 (MACN-Ar 39360), 25.XI.2016, L. Zapata coll., Malaise trap, 20 (MACN-Ar 39677), same locality and collector, 9.XII.2016, $10^{\prime}$ (MACN-Ar 39668), Camino de los Lagartos between Acceso Brasil and Camino del Medio, (S34 ${ }^{\circ} 36^{\prime 26.24}$ ', W58 $\left.21^{\prime} 28.78^{\prime \prime}\right)$, 10.XI.2014, L. Zapata coll., beating foliage, 1 우 (MACN-Ar 39319), same locality and collector, 9.XI.2015, 20 (MACN-Ar 39265), S34 $36^{\prime} 50^{\prime \prime}$ W58 $21^{\prime} 21^{\prime \prime}$ Google Earth, 12.XI.2019, beating foliage, L. Zapata (LVZLoc-49), 10 (MACN-Ar 41706) 10 10 , 1 (MACNAr 41764), Camino del Medio, (S34 36'30.35", W58 $\left.21^{\prime} 16.40^{\prime \prime}\right)$, elev. $3 \mathrm{~m}$ (GPS), 22.XII.2014, M. Izquierdo \& M. Bagur coll., beating in grasses 


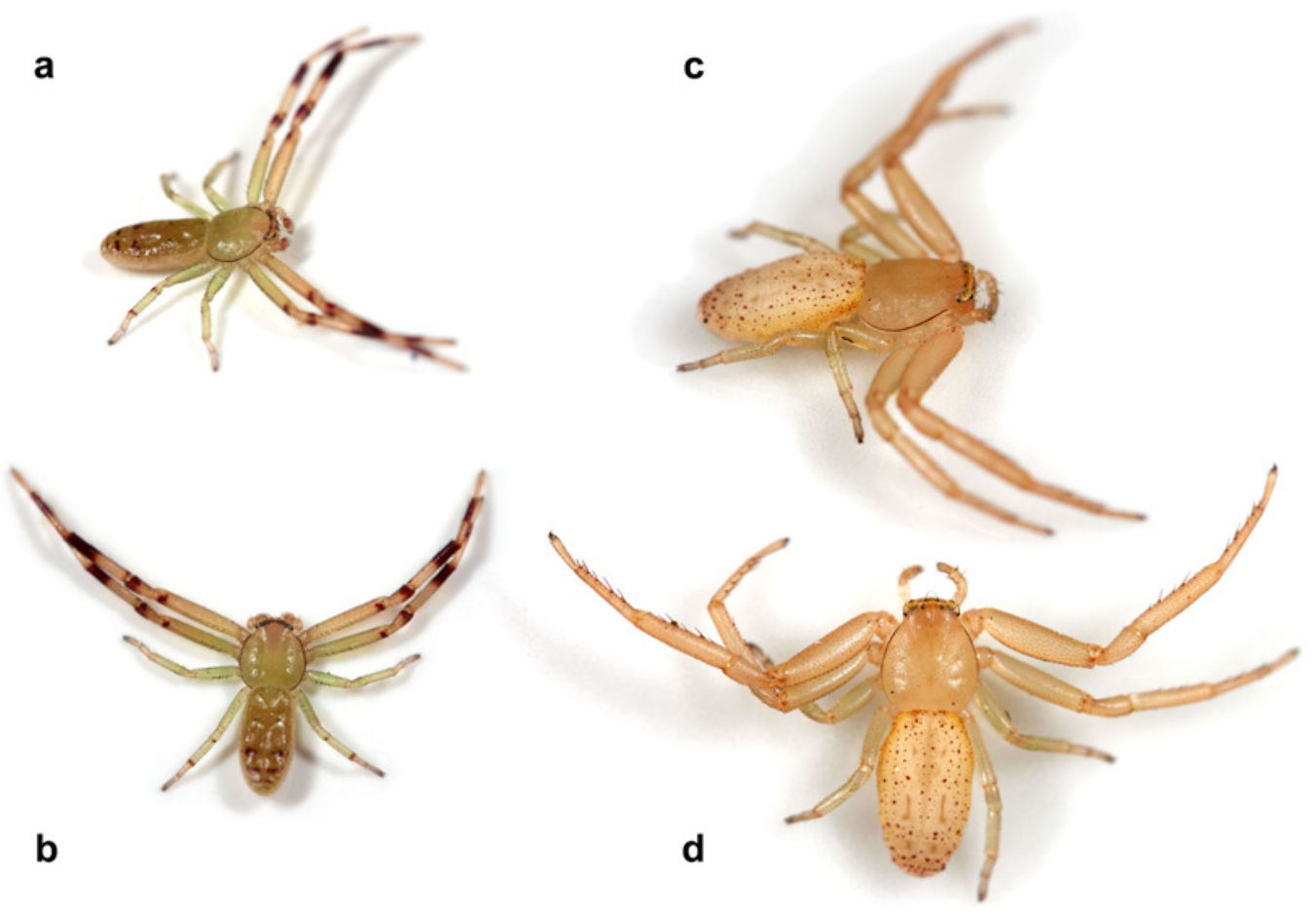

Fig. 28. Uraarachne plana (Simon), living specimens. a, b, male from Gualeguaychú (Entre Ríos); c, d, female from Curuzú Cuatiá (Corrientes). Photo credits: Martín J. Ramírez.

and tree foliage along the trail, $10^{\circ}$ (MACN-Ar 39358); La Pampa Province: Limay Mahuida: Limay Mahuida, (S379'33.42”, W6640'26.70'), VIII.1963, J. M. Gallardo coll. 19, (MACN-Ar 18673), Lihuel-Calel: Parque Nacional Lihué Calel, (S3759'44.66”, W65 35'31.64'), no date, no collector, 10 (MACN-Ar 19337); Chubut Province: Biedma: Puerto Lobos, $\left(\mathrm{S} 42^{\circ}\right.$ 0'13.47", W65 4'26.64"') I.1975, E. Maury coll. $10^{\prime}$ (MACN-Ar 18671).

Distribution. $U$. cornuta has the widest known distribution range for a species of this genus: Paraguay, Uruguay, nearly all the northern half of Argentina, in the Provinces of Salta, Formosa, Chaco, Corrientes, Santa Fe, Buenos Aires, and La Pampa, and with one record in Chubut province, in northern Argentinean Patagonia, (Map 4). Natural history. This species was collected by beating the foliage of medium size trees and shrubs, at margins of trails in Reserva Ecológica Costanera Sur and Reserva Ribera Norte, two localities close to the Río de la Plata estuary. One female from the later locality was collected with an eggsac. All known adult males were recorded between November and January (end of austral spring to summer).
Uraarachne brevipes (Simon, 1886) new combination

(Figs. 1a-d, Map 2)

Plancinus brevipes Simon, 1886: female holotype from "Banda Oriental del Uruguay" (currently, Uruguay), no locality detailed, presumably collected by Karl Berg, deposited in MNHN 5434, examined. Roewer 1955: 852; Bonnet 1956: 3698; Lehtinen 2004, 178.

Notes. The vial MNHN 5434 contains one adult female (Figs. 1a-d). We decided not dissect the epigynum because it is the only known specimen of the species, and because it could be easily recognized by somatic characteres.

Diagnosis. The female of $U$. brevipes is somatically similar to those of $U$. variegata by having a similar color pattern on carapace, with lateral paraxial dark bands, and a relatively short abdomen, but differs by the more remarkable protrusions on the ALE, by the more angular abdomen, and by the epigynum with a narrower median septum (Figs. 1a-c).

Description. See Simon (1886).

Distribution. Only known by the holotype from Uruguay. 


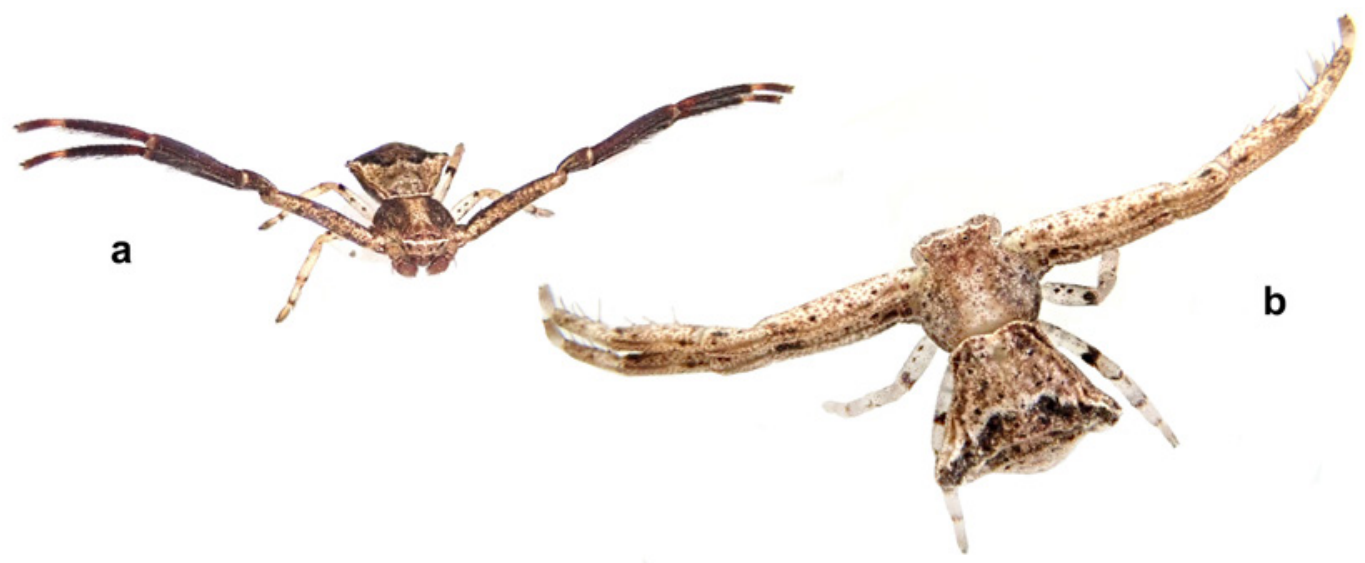

Fig. 29. Uraarachne cornuta (Simon), living specimens. a, male from Reserva Ecológica Costanera Sur (Ciudad de Buenos Aires); b, subadult female from Sarandí (Buenos Aires). Photo credits: Hernán Iuri.

Uraarachne panthera, new species (Figs. 21, 24b, e, 26b, e, Map 5)

Type material. Male holotype from Argentina: Misiones Province: Route 17, $44 \mathrm{~km} \mathrm{E.} \mathrm{Eldorado}$ (S2624'24.78”, W54³8'12.90”), 20.IX.1992, P. A. Goloboff coll., deposited in MACN-Ar 18791 (voucher CJG-1728).

Diagnosis. This species is recognizable mainly by the abdominal pattern (with ocellar markings on dorsum, Fig. 21a); the palp is similar to those of $U$. ceratophrys, but differs by the shorter embolus and RTA.

Description. Male holotype (MACN-Ar 18791, voucher CJG-1728, Fig. 21). Coloration (in ethanol): carapace brown, with a complex pattern of dark spots more dense at sides, appearing as lighter on the wide median area; eye region on light brown cuticle except a transverse white area between the two eye rows; endites and labium dark brown, sternum light brown with many dark spots, mostly concentrated at the lateral margins, chelicerae brown with median lighter transverse band, clypeus pigmented in white, as a continuous with the ocular area; legs I-II reddish brown (tibiae and metatarsi darker) with sparse dark spots, legs III-IV light brown, with annular markings on all articulations. Abdomen dorsally orange, with paraxial paired dark spots, some of they ocellar shaped (with dark borders with lighter center); posterior to the ocellar spots the paraxial markings are transverse, and short, not touching at middle; lateral folds with alternate white and dark pigment; the folds extends ventrally, leaving a median wide band with light brown stripes along marginal folds, especially on the caudal area; two paraxial rows of eight ocellar spots, flanked by white lateral bands. Measurements: body length 3.20, prosoma length 1.54 , width 1.54 , opistosoma lenght 1.84 , maximum width 1.44, legs: length of articles (femur, patella, tibia, metatarsus, tarsus, total): I $1.74,0.80,1.32,1.02,0.64,5.52$; II $1.60,0.66$, $1.22,0.84,0.52,4.84$; III $0.80,0.42,0.52,0.42$, $0.30,2.46$; IV 0.84, 0.42, 0.52, 0.42, 0.32, 2.52. Prosoma not very flattened, longer than wide, with short blunt setae. Eyes small, the region between ALE and PLE protuberant, eye diameters and interdistances: AME 0.04, ALE 0.08, PME 0.04, PLE 0.05, AME-AME 0.14, AME-ALE 0.14, PME-PME 0.24, PME-PLE 0.24. Labium nearly as long as wide (length 0.24 /width 0.22 ), sternum longer than wide (length $0.72 /$ width 0.66). Abdomen elongate pentagonal, truncated anteriorly, widest at the level of the two largest ocellar markings (anterior widht 1.06). Leg spination: I: femur D1-1-0-0, tibia V1-2-2-2, metatarsus V2-2-2-2-2-2; II: femur D1-1-0-0, tibia V1-2-2-2, metatarsus V2-2-0-2-2-2; III: femur D1; IV: femur D1. Metatarsus III and IV with an apical verticillum of small spines.

Genitalia: palp with relatively elongated and strongly sinuous RTA (with the tip strongly bent to the cymbium in dorsal and ventral view), with a ventral expansion relatively basal to the tip; bulb discoidal, medium sized, with embolus origin at nearly ten o'clock position (Figs. 21 g-j, $24 \mathrm{~b}, \mathrm{e}, 26 \mathrm{~b}, \mathrm{e})$.

Female unknown.

Etymology. The specific epithet refers to the 
genus of the jaguar Panthera onca Linnaeus an endangered and iconic member of the fauna of Misiones Province, and is an allusion to the ocellar shape of the spots on the dorsum of the abdomen of this species, resembling the jaguar's pigment pattern.

Distribution. Only known from the type locality, in Misiones Province, northeastern Argentina (Map 5).

\section{Uraarachne ceratophrys new species} (Figs. 22, 24c, f, 26c, f, Map 5)

Type material. Male holotype from Argentina: Misiones Province: Santa María (S2756'5.63', W 55²4'23.37'), XI-XII.1952, J. M. Viana coll., deposited in MACN-Ar 3544 (voucher CJG1729).

Diagnosis. This species is recognizable mainly by the prosoma wider than long, with remarkably granulate cuticle. The dark body coloration, with complicated pattern resembles that of $U$. cornuta, but $U$. ceratophrys shows two white diagonal bands on the dorsum of the abdomen, that is not pentagonal. The palp is similar to that of $U$. panthera, but differs by the longer embolus and also longer RTA (Figs. 22 g-j, 24c, f, 26c, f).

Description. Male holotype (MACN-Ar 3544, voucher CJG-1729, Fig. 22). Coloration in ethanol: Prosoma dark brown, with a complicated pattern of yellowish lines, with a median light stripe radiating forwardly to the eye region and to the lateral margins; white pigment limited to a narrow line between the two eye rows; endites, labium, and sternum yellowish, with dark markings (absent in the central part of the sternum; chelicerae light brown with small sparse dark dots; legs dark brown, profusely marbled in yellowish. Abdomen mostly brown with a complicated pattern of ocellar spots, and small white dots, combined with two laterally directed larger white bands (not touching at middle) and a reddish, chevron-like design posterior to these markings; lateral folds narrow, closely spaced, and dorsal apodemes inconspicuous; venter uniformly pale yellow. Measurements: body length 2.80 , prosoma length 1.38 , width 1.56 , opistosoma lenght 1.78 , maximum width 1.64 , legs: length of articles (femur, patella, tibia, metatarsus, tarsus, total): I 1.82, 0.78, 1.40, 1.24, 0.60, 5.84; II 1.70, 0.70, 1.24, 1.22, 0.60, 5.46; III 0.84, $0.42,0.48,0.44,0.28,2.46$; IV $0.84,0.40,0.52$, $0.42,0.30,2.48$. Prosoma flattened, longer than wide, with short blunt setae. Eyes small, the region between ALE and PLE remarkably protu- berant, and with additional pointed protrusions in front of the PME (Fig. 22d); eye diameters and interdistances: AME 0.05, ALE 0.08, PME 0.04, PLE 0.08, AME-AME 0.14, AME-ALE 0.16, PME-PME 0.24, PME-PLE 0.22. Labium as long as wide (length 0.24 /width 0.24 ), sternum longer than wide (length 0.70/width 0.62). Abdomen nearly pentagonal, truncated anteriorly, widest at the level of the large white markings (anterior width 1.20). Leg spination: I: femur D1-1-0, tibia V1-2-2-2-2 metatarsus V2-2-2-2-2-2; II: D1-0-0, tibia V0-2-2-2-2, metatarsus V2-2-2-2-2; III: femur D1-1-1; IV: femur D1-0-1-1-0 (in a zigzagging row). Metatarsus III and IV with an apical verticillum of small spines.

Genitalia: palp with relatively elongated and slightly sinuous RTA with a membranous area at the level of the ventral expansion, which is relatively basal to the tip, elongate and rather straight and parallel to the cymbium in dorsal and ventral view; bulb discoidal, medium sized, with embolus origin at nearly nine o'clock position (Figs. $22 \mathrm{~g}-\mathrm{j}$, $24 \mathrm{c}, \mathrm{f}, 26 \mathrm{c}, \mathrm{f})$.

Female unknown.

Etymology. The specific epithet refers to the amphibian genus Ceratophrys Wied-Neuwied, the South American horned frogs, and is an allusion to the acute lateral ocular projections and rugose cuticular texture of this species, resembling the head and skin of these frogs.

Distribution. Only known from the type locality, in Misiones Province, northeastern Argentina (Map 5).

\section{DISCUSSION}

At this time, the elongated abdomen, ending in a caudal projection beyond the spinnerets, is the only diagnostic character for the genus Uraarachne. All other morphological characters resemble to those of Runcinia, genus mostly distributed in Africa and Asia, with a few species in the Palearctic and Australian regions. It comprises species with very conservative genital morphology, but with a wide spectrum of variation in somatic aspects, such as the degree of lateral protrusion of the ocular area, shape of carapace, and especially abdominal shape (see DippenaarSchoeman, 1980; Ono, 1988; Szymkowiak, 2014). The abdomen may be short, wide and posteriorly rounded (the type species, Runcinia grammica Simon), slightly more elongated and posteriorly rounded (some African and Oriental species such as $R$. tropica Simon, R. depressa Simon, $R$. insecta (L Koch)), truncated (e.g., R. aethi- 


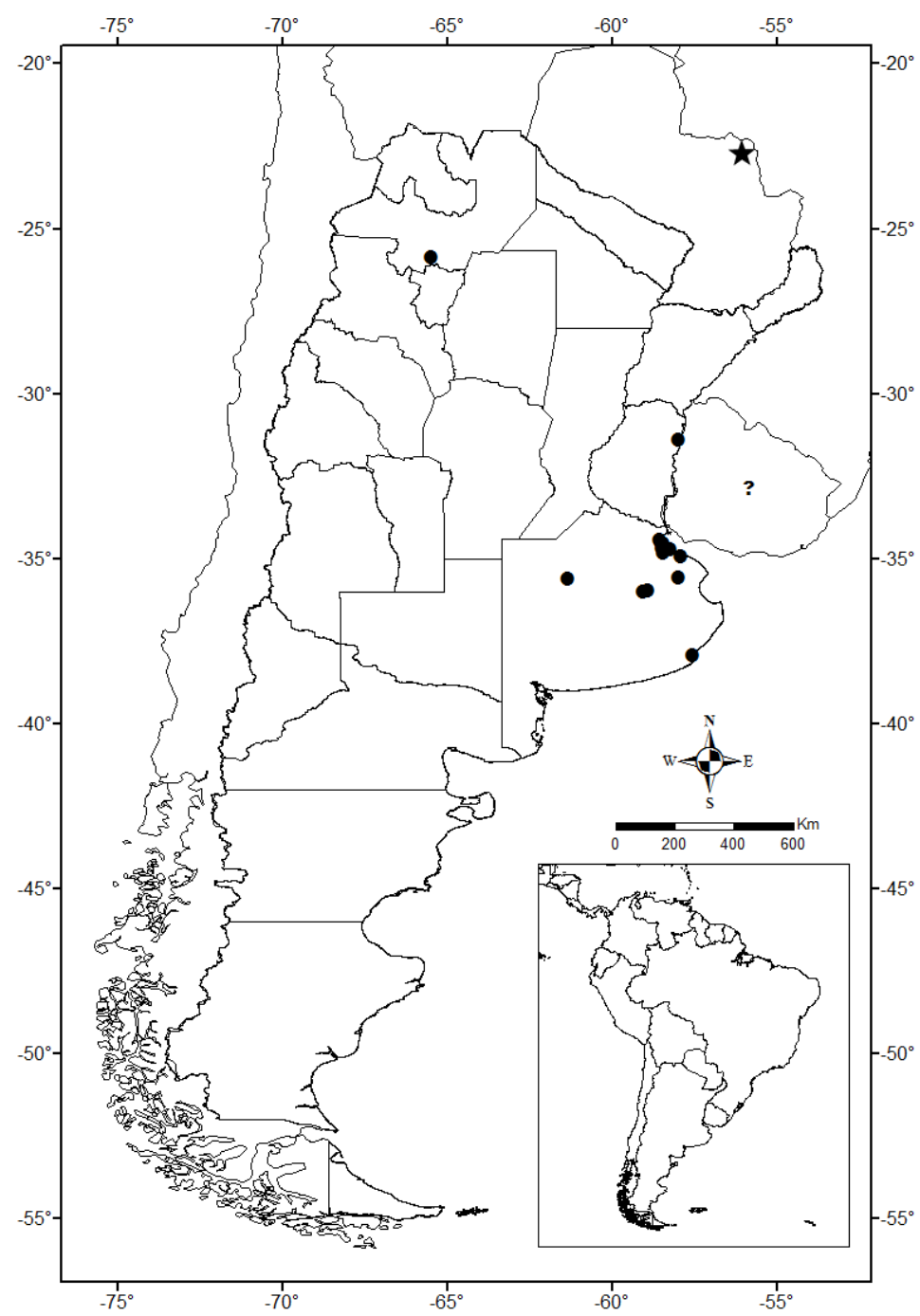

Map 1. Distribution of Uraarachne longa Keyserling in Paraguay (star), and Uraarachne runcinioides (Simon) (circles). Question mark: uncertain locality of the type specimens of U. runcinioides in Uruguay.

ops (Simon)), or elongated (e.g., $R$. acuminata (Thorell), R. flavida (Simon), and R. johnstoni $D$ e Lessert). Interestingly, $R$. johnstoni has a caudal projection similar to that of Uraarachne longa (Dippenaar-Schoeman 1980: fig. 8).

The RTA of Runcinia and Uraarachne are relatively simple, and have an internal row of ridges (Figs. 4 a-b, d-f, 5 a-b, d-f, $6 a-b$, d-f, 23-26). Besides genitalic features, other characters shared by Uraarachne and typical Runcinia such as R. grammica (C. L. Koch, 1837) are the similar body setae, presence of lateral folds on the abdomen, and the conspicuous pointed setae along the lateral margin of cara- pace (see, for example, Figs. 8d, 9d, 13d, 21d).

The main somatic differences we found between Runcinia grammica and Uraarachne are that $R$. grammica has: (1) a relatively broader and less protruding cephalic area (with correspondingly broader ocular area), and (2) smaller leg spines, especially in females (all ventral spines are shorter, and also reduced in number on tibiae). Although these features show variation if we consider the rest of the species of Runcinia (distributed throughout the Ethiopian and Oriental Regions), there are consistent genitalic features that allow us to distinguish all species of Uraarachne from those of Runcinia. In 


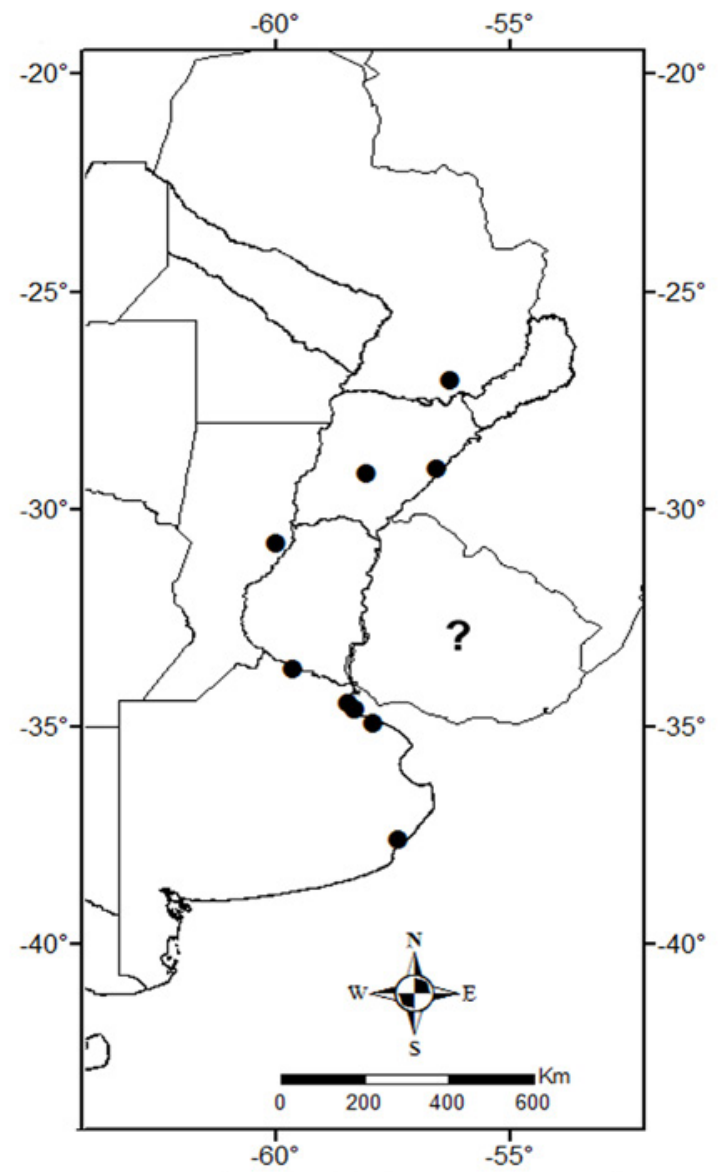

Map 2. Distribution of Uraarachne variegata (MelloLeitão) (circles), and Uraarachne brevipes (Simon) (question mark = uncertain locality in Uruguay).

Runcinia the RTA is relatively short and nearly straight (Figs. 6d-f, 8 i-j; Millot 1941, Ono 1988, Dippenaar-Schoeman 1980, Szymkowiak 2014), while in Uraarachne it is longer and slightly curved (Figs. 4 a-b, d-f, 5 a-b, d-f, 23-26), with a ventral expansion, which could be result of a fusion of the RTA and the ITA. Another character of Uraarachne is the tegular pocket, an indentation of the tegulum at the level of the internal end of the spiral groove of tegulum (TP in Figs. $4 \mathrm{a}, 5 \mathrm{a}$ ), making visible most of the embolus base; that indentation is absent in Runcinia species. A similar structure, probably homologous, was observed in Misumenops and Mecaphesa Simon (see Lehtinen \& Marusik 2008: figs. 1, 5, 10, 42). Concerning the female genitalia, all known Uraarachne species have relatively short, inconspicuous copulatory ducts (Figs. 5h, 9i, 10i, 12i, 14i, 16i, 18i, 19i), while Runcinia grammica, as well as other species illustrated in the literature

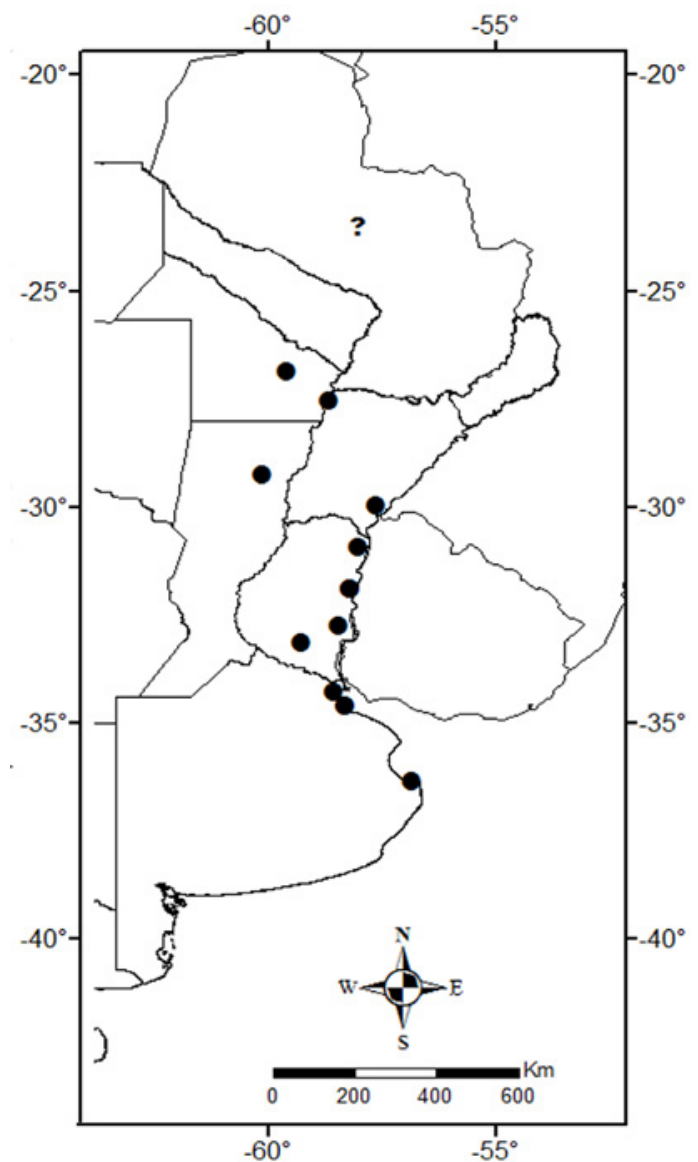

Map 3. Distribution of Uraarachne plana (Simon). Question mark: uncertain locality of the type specimens in Paraguay.

has longer copulatory ducts, sometimes coiled (Fig. 7i, Dippenaar-Schoeman 1980: figs. 3, 10, 15, 20, 36, 39; Ono 1988: figs. 189, 195). Then, we can recognize a South American group for what Uraarachne is the older available name, united by two putative synapomorphies: the curved RTA (presumably fused to the ITA), and the tegular pocket.

Although the diagnosis of Uraarachne herein proposed could be sufficient to distinguish this genus from most other Misumenini, there is still a persistent difficulty with the wide concept of Misumenoides Pickard-Cambridge, 1900. Misumenoides was diagnosed by several authors (for example, Lehtinen 2004: 173) with the same features as some species formerly included in Plancinus (transverse white ocular carina and truncated abdomen). For example, Gertsch (1939: 309) commented that "... Runcinia of the Eastern Hemisphere is replaced in the Americas 


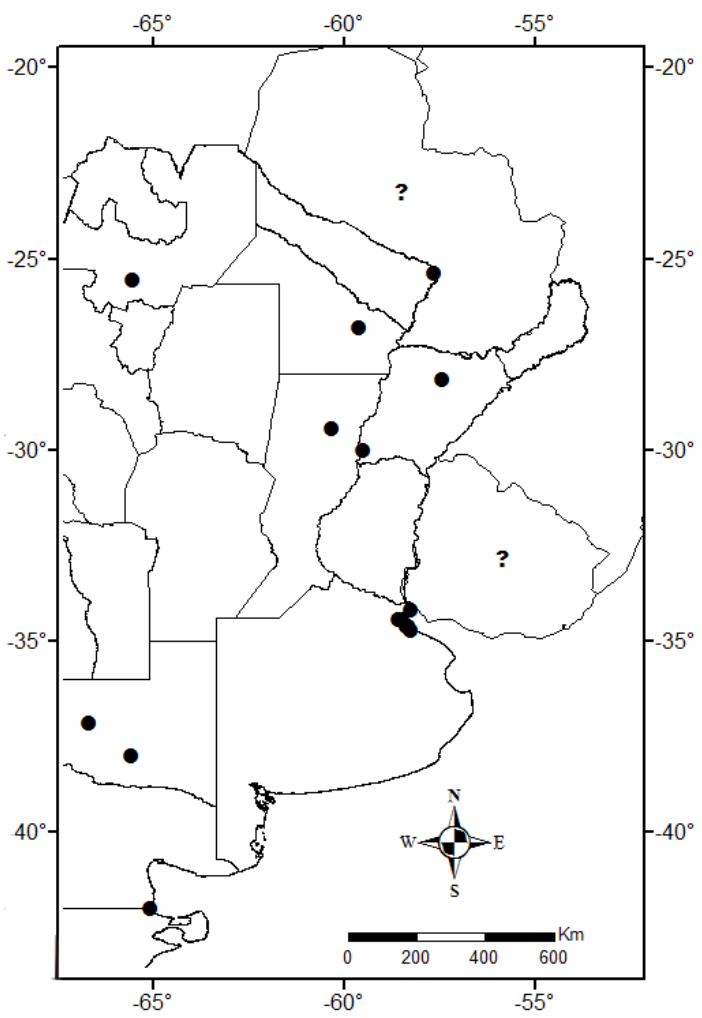

Map 4. Distribution of Uraarachne cornuta (Simon). Question marks: uncertain localities of the type specimens in Uruguay and the specimen from Paraguay (MNHN 92032).

by the closely related group of species placed in Misumenoides by F. O. P. Cambridge." The type species of this genus is Misumenoides magnus (Keyserling, 1880), that was also described originally in Runcinia. In recent years, most researchers overlooked the generic concept of Plancinus, and only considered Misumenoides for adscribing species with that combination of characters. For example, Teixeira \& Lise (2012) transferred Petrichus athleticus Mello-Leitão to Misumenoides, and Zapata \& Grismado (2015: 205 and fig. 4b) reported two specimens from "Costanera Sur" Ecological Reserve in Buenos Aires city, as "Misumenoides sp. indet." (here identified as Uraarachne cornuta). We didn't have the possibility to study the type species of Misumenoides, but, we had access to good photographs of the type series of $M$. magnus. This species has a more convex and elevated carapace, relatively small eyes, the male palp lacks the tegular pocket, the RTA is long, narrow and straight, and the epigynum has a very small and

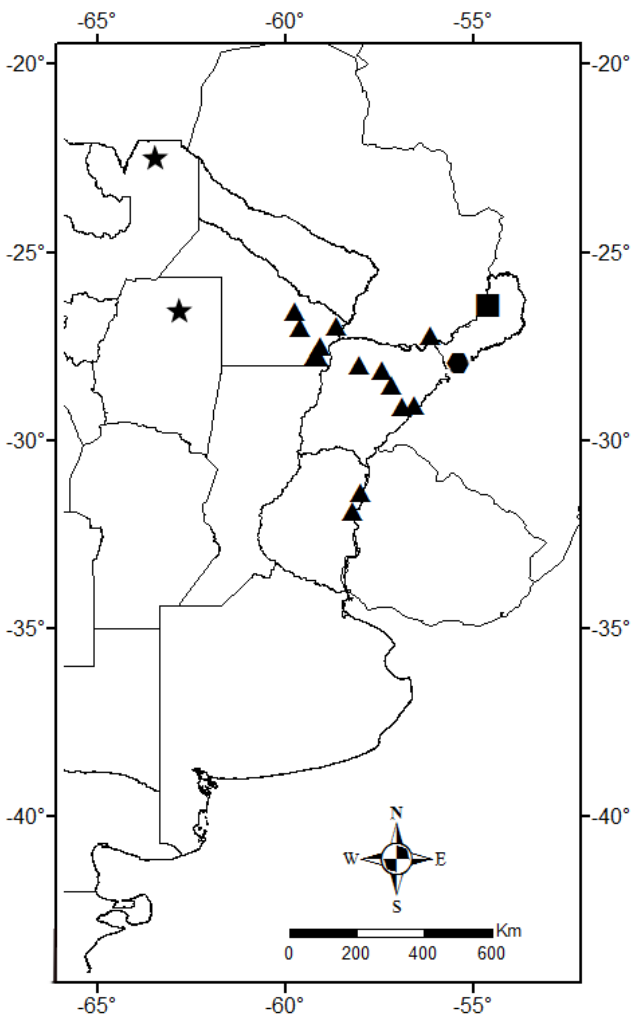

Map 5. Distribution of the new species of Uraarachne: $U$. kapiity n. sp. (triangles), U. toro n. sp. (stars), $U$. panthera n. sp. (square), and $U$. ceratophrys n. sp. (hexagon).

narrow hood (Figs. 3a-h). All these features suggest that Misumenoides (or at least the species closely related to $M$. magnus) is different from Uraarachne and Runcinia, and that it also should be revised in order to elucidate its limits.

Concerning the relationships, Uraarachne could be included in the tribe Misumenini, by their strong sexual dimorphism and dark annulations on legs I-II of males (Lehtinen, 2004), and a "coupling pocket" (here called anterior hood) in the female epigynum (Faleiro \& Santos, 2019). Further characters shared with other genera currently assigned to Misumenini are: the tegular pocket (present, among others, in Misumenops and Mecaphesa), and the RTA with internal rows of ridges, that is also found in Runcinioides Mello-Leitão, Misumenops and Henriksenia (Faleiro \& Santos 2019, Lehtinen 2004).

\section{ACKNOWLEDGEMENTS}

We thank Luis Pereira, Mónica Tassara, and Cristina Damborenea (MLP), Peter Jäger 
and Julia Altmann (SMF), Jason Dunlop and Anja Friederichs (ZMB), Christine Rollard and Elise-Anne Leguin (MNHN), John Kochalka and Yolanda Piñánez Espejo (MNHNP) for loaning specimens for this study, and to Janet Beccaloni (BMNH) and Juan Farina (MMPE) for allowing access to the collections under his care; we especially thank the staff of all these institutions for their hospitality. We thank Ricardo BoteroTrujillo for having managed the search for the type series of Misumenoides magnus in London, and especially to Danni Sherwood for taking the photos of this material; to Luciano Peralta for finding the specimens deposited in Mar del Plata and for sharing his records; to all our co-collectors for their help and assistance in the field (especially to Gilberto Ávalos), and to Lorena Zapata, Hernán Iuri, and Martín Ramírez for the photographs of living specimens. The fieldwork was possible after obtaining permits from the authorities (and their Institutions) of Reserva Ecológica Costanera Sur (Ciudad Autónoma de Buenos Aires), Subdirección de Ecología y Conservación de la Biodiversidad de la Municipalidad de San Isidro, (Buenos Aires Province), Dirección de Recursos Naturales del Ministerio de Producción, Trabajo y Turismo (Corrientes Province), and Administración de Parques Nacionales of Argentina (APN).

We are greatly endebted to Martín Ramírez, Renato Teixeira, one anonymous referee, and the editor Andrés Ojanguren Affilastro for comments that helped improving sucessive versions of the manuscript, and to Abel Pérez González, Luis Piacentini, and Ivan Magalhães for discussing some taxonomic and nomenclatural issues.

Visits to the MNHN and ZMB collections were made possible by a CONICET fellowship to C.J.G. for studying European collections. Further financial support to this work came in the form of grants from FONCyT (PICT 2015-0283 and 2017-2689) to Martín Ramírez.

\section{BIBLIOGRAPHY}

Álvarez-Padilla, F. \& Hormiga G. 2008. A Protocol For Digesting Internal Soft Tissues And Mounting Spiders For Scanning Electron Microscopy. The Journal of Arachnology 35(3): 538-542.

Bonnet, P. 1956. Bibliographia araneorum. Douladoure Toulouse 2(2): 919-1926.

Brignoli, P.M. 1983. A catalogue of the Araneae described between 1940 and 1981. Manchester University Press, 755 pp.

Caporiacco, L. di. 1954. Araignées de la Guyane Française du Muséum d'Histoire Naturelle de
Paris. Commentationes Pontificia Academia Scientiarum 16: 45-193.

Dippenaar-Schoeman, A.S. 1980. The crab-spiders of southern Africa (Araneae: Thomisidae). 1. The genus Runcinia Simon, 1875. Journal of the Entomological Society of South Africa 43: 303-326.

Dippenaar-Schoeman, A.S. 1983. The spider genera Misumena, Misumenops, Runcinia and Thomisus (Araneae: Thomisidae) of southern Africa. Entomology Memoir, Department of Agriculture Republic of South Africa 55: 1-66.

Dupérré, N. \& Harms, D. 2018. Raising the dead: rediscovery and redescription of some lost spider types (Araneae) described by Eugène Simon. Evolutionary Systematics 2: 1-20.

Faleiro, B.T. \& Santos, A.J. 2019. Revision of the crabspiders of the genus Runcinioides Mello-Leitão, 1929 (Araneae, Thomisidae). Zootaxa 4567(1): 2546.

Gertsch, W.J. 1939. A revision of the typical crab spiders (Misumeninae) of America north of Mexico. Bulletin of the American Museum of Natural History 76: 277-442.

Keyserling, E. 1880. Die Spinnen Amerikas, I. Laterigradae. Bauer und Raspe, Nürnberg, 283 pp.

Lehtinen, P.T. 2004. Taxonomic notes on the Misumenini (Araneae: Thomisidae: Thomisinae), primarily from the Palaearctic and Oriental regions. In: Logunov, D. V. \& D. Penney (eds.) European Arachnology 2003 (Proceedings of the 21st European Colloquium of Arachnology, St.Petersburg, 4-9 August 2003). Arthropoda Selecta, Special Issue 1: 147-184.

Loerbroks, A. 1983. Revision der KrabbenspinnenGattung Heriaeus Simon (Arachnida: Araneae: Thomisidae). Verhandlungen des Naturwissenschaftlichen Vereins in Hamburg 26: 85-139.

Mello-Leitão, C.F. de (1929d). Aphantochilidas e Thomisidas do Brasil. Arquivos do Museu Nacional do Rio de Janeiro 31: 9-359.

Mello-Leitão, C.F. de. 1931. Notas sobre arachnidos argentinos. Anais da Academia Brasileira de Ciências 3: 83-97.

Mello-Leitão, C.F. de. 1944. Arañas de la provincia de Buenos Aires. Revista del Museo de La Plata (N.S., Zool.) 3: 311-393.

Millot, J. 1941. Les araignées de l'Afrique Occidentale Français: Thomisidae. Mémoires de l'Académie des Sciences de Paris (2) 65: 1-82.

Ono, H. 1988. A revisional study of the spider family Thomisidae (Arachnida, Araneae) of Japan. National Science Museum, Tokyo, $252 \mathrm{pp}$.

Petrunkevitch, A. 1928. Systema Aranearum. Transactions of the Connecticut Academy of Arts and Sciences 29: 1-270.

Ramírez, M.J. 2014. The morphology and phylogeny of dionychan spiders (Araneae: Araneomorphae). Bulletin of the American Museum of Natural History 390: 1-374.

Rinaldi, I.M.P. 1988. Misumenops Cambridge e 
Uraarachne Keyserling (Araneae, Thomisidae, Thomisinae): Sinonímias, novas combinações e redescrições. Revista Brasileira de Entomologia 32: 19-30.

Roewer, C.F. 1955. Katalog der Araneae von 1758 bis 1940, bzw. 1954. 2. Band, Abt. a (Lycosaeformia, Dionycha [excl. Salticiformia]). 2. Band, Abt. b (Salticiformia, Cribellata) (Synonyma-Verzeichnis, Gesamtindex). Institut royal des Sciences naturelles de Belgique Bruxelles, 1751 pp.

Silva-Moreira, T. 2010. On the collection of Thomisidae (Arachnida: Araneae) of Museu Nacional, Rio de Janeiro (MNRJ), Brazil. Boletim do Museu Nacional (nova série) Zologia, Rio de Janeiro, 67(1-2): 61-72.

Simon, E. 1886. Espèces et genres nouveaux de la famille des Thomisidae. Actes de la Société Linnéenne de Bordeaux 40: 167-187.

Simon, E. 1892. Histoire naturelle des araignées. Deuxième édition, tome premier. Roret Paris, pp. 1-256.

Simon, E. 1895a. Histoire naturelle des araignées.
Deuxième édition, tome premier. Roret Paris, pp. 761-1084.

Simon, E. 1895b. Descriptions d'arachnides nouveaux de la famille des Thomisidae. Annales de la Société Entomologique de Belgique 39: 432-443.

Simon, E. 1909. Etude sur les arachnides du Tonkin (1re partie). Bulletin Scientifique de la France et de la Belgique 42: 69-147.

Szymkowiak, P. 2014. Revision of Australian species of the genus Diaea (Araneae: Thomisidae) with redefinition of their taxonomic status. Annales Zoologici, Warszawa 64(3): 333-477.

Teixeira, R.A. \& Lise, A.A. 2012. Redescription of Misumenoides athleticus comb. nov. (Araneae: Thomisidae), wrongly assigned to the philodromid genus Petrichus. Zoologia (Curitiba) 29: 380-384.

Zapata, L.V. \& Grismado, C.J. 2015(2016). Lista sistemática de arañas (Arachnida: Araneae) de la Reserva Ecológica Costanera Sur (Ciudad Autónoma de Buenos Aires, Argentina), con notas sobre su taxonomía y distribución. Revista del Museo Argentino de Ciencias Naturales (n. s.) 17(2): 183-211.

Doi: 10.22179/REVMACN.22.665

Recibido: 20-XI-2019

Aceptado: 20-V-2020 